\title{
AVATARES BARROCOS DEL ROMANCE (DE GÓNGORA A SOR JUANA INÉS DE LA CRUZ)
}

\author{
A la memoria de Alfonso Méndez Plancarte. \\ A la amistad de Tomás Segovia \\ $y$ de José Luis Gotor.
}

"La historia de la métrica española está por escribir". Tales son las primeras -y justas- palabras del libro en que Emiliano Diez Echarri estudia las teorias métricas del Siglo de Oro ${ }^{1}$, una de las pocas contribuciones serias que se han hecho para la escritura de esa historia. El presente artículo pretende aportar algunos materiales para uno de sus capítulos. Materiales un tanto recónditos a veces (cuando proceden de esos libros que se han hecho rarísimos porque nadie los lee, o que nadie lee porque se han hecho rarísimos), pero en general bastante accesibles, que sólo hacía falta poner en cierto orden o en cierta perspectiva.

El hipotético capítulo o capituliho cuya escritura, hipotéticamente, se facilitaría gracias a mi trabajo podría intitularse "La barroquización del romance". Empleo la palabra barroco y sus deri-

I Emplearé en adelante las siguientes abreviaturas:

A. M. P., $P N=$ Alfonso Méndez Plancarte, Poetas novohispanos, tomos 2 y 3: 1621-1721, México, 1943 y 1945.

A. M. P., $S J=$ Obras completas de Sor Juana Inés de la Cruz, editadas por Alfonso Méndez Plancarte [salvo el último tomo, editado por Alberto J. Salceda], México, 1951-1957; 4 tomos.

BAEHR = Rudolf BAEHR, Manual de versificación española, Madrid, 1970.

Echarri = Emiliano DíEz Echarri, Teorias métricas del Siglo de Oro. Apuntes para la historia del verso español, Madrid, 1949.

P. H. U. = Pedro Henríquez UReña, Estudios de versificación española, Buenos Aires, 1961.

T. N. T. = Tomás Navarro Tomás, Métrica española. Reseña histórica y descriptiva, Syracuse, N. Y., 1956.

Citaré a Góngora por la edición de Juan e Isabel Millé y Giménez, Madrid, [1932], y a LoPe de VEGA por la edición que de algunas de sus Poesias liricas hizo José F. Montesinos en Clás. cast., 2 tomos, Madrid, 1925 y 1926. 
vados en un sentido muy inocente, muy poco presuntuoso. Desde fines del siglo xvi el romance va dejando, cada vez más, de ser simplemente una "serie más o menos extensa de octosílabos, con los versos pares rimados bajo la misma asonancia y con los impares sueltos", como lo define T. N. T., p. 532. No sólo surgen romances en versos de distintas medidas -en particular los de once sílabas-, sino que estos versos se agrupan en estrofas de tamaños diversos, y, cuando las estrofas constan de cinco o de siete versos, ocurre que la asonancia, después de caer en los pares, cae luego en los impares. Estos y otros fenómenos de innovación y de experimentación abundan a lo largo del siglo xvn, particularmente en su segunda mitad, o sea en la época de Sor Juana Inés de la Cruz, en cuya producción poética hay una variedad extraordinaria (no igualada, que yo sepa, por la de nimgún otro autor) de romances compuestos en versos no octosílabos y en estrofas que no son la simple cuarteta. A cosas así, según se irá viendo en el cuerpo de mi artículo, me refiero con la palabra "barroquización". Sor Juana es, en este sentido, el poeta más representativo del Barroco español, su culminación más visible.

El cuerpo de mi trabajo está constituido por un Catálogo de formas que, obviamente, no incluye sino las que he podido recoger, aunque tengo la impresión de que una búsqueda minuciosa y metódica arrojaría, más que formas nuevas, nuevas muestras de las que yo y los investigadores en quienes me apoyo hemos encontrado.

Pero antes de ofrecerle al lector mi Catálogo, necesito pedirle qué me acompañe en el intento de ver con cierta claridad qué fue lo que se barroquizó. Por eso, sin meterme en los orígenes remotos y semisombríos del romance español, comenzaré por exponer algunas consideraciones destinadas a situar esa forma poética en su trasfondo.

\section{ANTECEDENTES}

El índice o "Tabula per ordinem alphabeticum" del Cancionero musical de Palacio, compilado en tiempo de los Reyes Católicos 2 , distingue entre "villancicos", "estrambotes" y "romances". De éstos, registra cuarenta y cuatro. Pero, según los criterios modernos, habría que suprimir nueve, a saber: núms. 81 (coplas castellanas), 93 (cuarteta aconsonantada $a b a b$ ) , 95 (villancico con música incompleta), 103 (análogo al 81), 104 (cuarteta aconsonantada $a b a b$ ), 128 (coplas zejelescas), 145 (villancico con música incompleta),

2 Cito por la edición de Higinio Anglés, Barcelona, tomos 1 (1947) y 2 (1951) . La "Tabula per ordinem alphabeticum" se publica en el t. 1, pp. 18-22. T. N. T. cita por la edición de Francisco Asenjo Barbieri. (En los párrafos siguientes, yo "traduciré" sus referencias a la ed. moderna). 
152 (villancico) y 381 (composición aconsonantada, un tanto anómala). Además, el romance "Por las sierras d'Avilla" estaba en un folio que hoy falta (como muchos otros) en el manuscrito de la biblioteca de Palacio.

Los treinta y cuatro romances auténticos que quedan (uno de ellos, el núm. 143, sin música) constituyen, sin embargo, un número respetable, sobre todo si se considera que se trata de la recopilación ${ }^{3}$ más antigua que existe de este género poético-musical. Pero, por otra parte, y siempre de acuerdo con los criterios modernos, habría que pasar a la lista de romances varias composiciones que la "Tabula" registra como villancicos.

Ya T. N. T., p. 155, menciona "el [romance] de la Cautiva", núm. 254 ("Mi madre, por me dar plazer, / a coger rrosas m'envía; / moros andan a saltear / y a mí llévanme cativa; / el moro que me prendiera / allende la mar m'envía..."), que es, en efecto, un romance hecho y derecho.

T. N. T. cita además (pp. 155-156) "el romancillo «Yo me iba mi madre / a la romería»", núm. 20, y dice que los núms. 235 y 269 son "del mismo tipo".

En cuanto al núm. 20, no cabe duda: es un romance de veinte versos, lindísimo, por cierto, perfectamente hexasilábico, a diferencia del que parece su antecedente inmediato, "Yo me iba, mi madre, / a Villa Reale..." (conocido con el nombre de Serranilla de la Zarzuela), que, como dice T. N. T., p. 139, tiene algunos heptasílabos y hasta un octosílabo.

El núm. 235, canción de vieja borracha, dice así:

Por mal vi, comadre,

tu vino pardillo,

que allá me tenías

mi saya y mantillo.

Que allá me tenías

mi saya y mantillo;

relanpaguéame'l ojo,

láteme'l colodrillo.

No hay por qué no darle la razón a T. N. T.: se trata de un romancillo muy breve, de solos seis versos ${ }^{4}$ (los dos. últimos, por cierto, no hexasilábicos).

3 Originalmente, los romances estaban concentrados en una sección, del folio 51 al 87; más tarde, "pero siempre a fines del siglo $\mathrm{xv}$ y principios del xvi" (Anglés), "diversas manos" aprovecharon, aquí y en otros lugares, los espacios en blanco para copiar más composiciones.

4 Si resultan dos cuartetas, es a causa del encadenamiento. La "edición critica de los textos" del Cancionero musical de Palacio por J. Romeu Figueras, Barcelona, 1965, desconcierta a veces, y a veces decepciona. (Prácticamente no 
Pero el núm. 269 es, en los dos sentidos, otro cantar. Dice así:

Madre, la mi madre, el mi lindo amigo moricos de allende Io llevan cativo, cadenas de oro, candado morisco.

Aquí la designación "romancillo" me parece muy dudosa. Sería el único ejemplo de romance cantado en tiradas de seis versos. Puestos a imaginar la ley de esta composición, o sea la clase de coplas que podría haber después de la única que nos da el Cancionero, lo que se ocurre es más bien una estrofa paralelística: "Madre, la mi madre, / el mi lindo amado..." 5 .

En cambio, y siempre según los criterios modernos, yo pasaría a la lista de romances el núm. 359, ocho versos de asonancia $a ́ a$ ("Ju me levé un bel matín, / matineta per la prata..."), que gracias al encadenamiento hacen tres cuartetas octosílabas), y sobre todo el núm. 346, romancillo de dieciséis hexasílabos perfectos, asonancia á-o ("Estáse el pastor / con el su ganado...").

La razón de que estos que ahora llamaríamos romances ${ }^{6}$ se re-

la he utilizado para nada). A propósito de este núm. 235 afirma Romeu de manera perentoria: "La presente composición nos ha conservado el refrán y dos dísticos de cosaute [ = canción paralelística], correspondientes ambos a una sola voz alternante", lo cual equivale a postular dos lineas paralelas a partir de una sola. Según él, por lo visto, donde hay encadenamiento debe haber también paralelismo. Pero no es así. El encadenamiento existe en el ya mencionado núm. 20 ("Yo me iba, mi madre, / a la romería; / por ir más devota / fui sin compañía. // Por ir más devota / fuy sin compañía; / tomé otro camino, / dexé el que tenía...", etc.), pero sería absurdo concluir que se nos ha conservado una sola de las "voces alternantes", la de asonancia $i-a$, y que nos falta la otra, de asonancia $a$ - $a$. Además, para varios de los romances clasificados como tales en la "Tabula", el arreglo de la letra en la partitura da testimonio de que se cantaban asimismo con encadenamiento; asi para el núm. 113 ("Si d'amor pena sentís, / por mesura y por bondat, / cavalleros, si a Francia is / por Gayferos preguntad. // Cavalleros, si a Francia is / por Gayferos preguntad, / y dezilde que su amiga / se le envía encomendar...", etc.); así también para los núms. 123, 136 y 137. (Si de esa manera se cantaban todos, habrá que pensar lo que duraria, por ejemplo, el de Conde Claros).

5 En esta imaginación sí puedo acompañar a Romeu Figueras, que dice: "Composición evidentemente fragmentaria... Es posible que sea un trístico de cosaute con su refrán” (o sea con su estribillo "iAy, que non hay, / mas ay, que non era / quien de mi pena se duela!').

- Por lo antes dicho, no cuento el núm. 269; pero en cambio, y ya en vena especulativa, sugeriría añadir otros, como el núm. 327 ("Yo me levantara un lunes, / un lunes antes del día...") y el 366 ("Yo m'iva, mi madre, / las rrosas coger..."), que positivamente parecen anunciar romances de los cuales, por 
gistren como villancicos en la "Tabula" del Cancionero me parece muy clara: todos ellos tienen estribillo (254: "Aquella mora garrida, / sus amores dan pena a mi vida"; 20: "So ell enzina, enzina, / so ell enzina"; 235: "Por bever, comadre, / por beber"; 359: "Din dirindín dirindín dirindaña, / din dirindín"; y 346: "Miedo m'é de Chiromiro, / a la he, / que del Chiromiro miedo m'é"). Un siglo después, en tiempos del Romancero general, tan romances eran los que tenían estribillo como los que carecían de él. Para el redactor de la "Tabula" del Cancionero musical de Palacio, eran dos cosas distintas. En la partitura de los que él llama romances no hay los signos de repetición y de da capo que son de rigor en la de los villancicos. De una sola ojeada ${ }^{7}$ podía saber a qué atenerse. El romance de la Cautiva, el de la Niña romera, y los demás, no eran para él romances, sino villancicos, piezas en que alternan coplas y estribillo -igual que en "Éramonos tres ermanas...", núm. 389-, y, correlativamente, una composición como la serie de redondillas del núm. 81, donde no hay estribillo, era, según sus cánones prácticos (musicales), un verdadero romance.

"A fines del siglo Xv", dice BaEHR, pp. 214-215, aparece en el romance una "tendencia hacia la disposición en cuartetas"; añade que "desde Gabriel Lobo Lasso de la Vega (1589) se asegura la disposición en cuartetas como unidad de composición, y a ella se aspira en forma consecuente", remitiendo en nota, para esto último, a S. G. Morley, "Are the Spanish romances written in quatrains?", $R R, 7$ (1916) , 42-46. Estas afirmaciones, más o menos calcadas de las de T. N. T. ${ }^{8}$, están pidiendo a gritos un poco de crítica. ¿Por

desgracia, no se copiaron más que los primeros versos. Lo malo es que los primeros versos del núm. 389 ("Éramonos tres ermanas / y comigo que son quatro; / todas tres son ya casadas, / de mi no tienen cuidado") parecen también comienzo de romance, y aquí sí hay más coplas, y estas coplas no sólo no mantienen la asonancia, sino que son aconsonantadas. El estribillo del núm. 356 (" $O$ castillo de Montanges, / por mi mal te conoçí! / Cuitada de la mi madre, / que no tiene más de a mí) se diría también un comienzo de romance, y no es sino un villancico perfecto ( $\mathrm{y}$ muy bello). - Otra sugerencia más aventurada: ver en el núm. 253 un doble romance, "Perdí la mi rrueca / llena de lino..." (asonancia $i-o$, diez versos) y "Perdi la mi rrueca / llena d'estopa..." (asonancia $\dot{o}-a$, también diez versos); fatalmente, esta especulación nos arrastraria hasta el famoso cosaute del viejo Hurtado de Mendoza, "Aquel árbol que mueve la hoja..." (dos romancillos entreverados, asonancia $\dot{a}$ y asonancia $\dot{e}$ ) у a no sé cuántas cantigas gallego-portuguesas...

7 Demasiado rápida a veces: si puso los núms. 95 y 145 entre los romances fue seguramente porque no hay en su música signos de repetición ni de $d a$ copo. En cambio, puso erróneamente entre los villancicos el núm. 85 ("Por mayo era, por mayo..."), donde si hay los mencionados signos, aunque luego, dándose cuenta del error, volvió a registrarlo entre los romances.

8 Cf. T. N. T., p. 154: "En la disposición de los versos [del romance] con- 
qué desde Gabriel Lobo Lasso de la Vega, uno de tantos cultivadores del Romancero nuevo? ¿Por qué no, digamos, desde Góngora, cuyos primeros romances (a partir de 1580) están ya escritos en cuartetas? Morley llamó la atención sobre algo, suscitó un problema, pero no dijo ninguna última palabra. Era de esperar que Baehr hubiera tenido en cuenta las críticas de Georges Cirot, resumidas por Echarri, p. 204, nota ("el criterio de Morley es demasiado estrecho, demasiado mecánico"), y las del propio Echarri allí mismo ("la tesis de Morley es muy discutible y su razonamiento muy endeble", etc.) ${ }^{9}$. Una cosa, como muy bien dice Echarri, es la "expresión escrita" de los romances y otra su "movimiento interno". Y además, una cosa es la práctica de Sepúlveda y Timoneda y los demás continuadores - tan aburridos casi siempre, tan genuinamente prosaicos- de la tradición del romance noticioso, donde el cuartetismo no es, a ojos vistas, la ley (como tampoco lo es en el romance que sirve para las relaciones o para el simple diálogo en la comedia española) ${ }^{10}$, y otra cosa es el romance lírico, o sea el destinado al canto, concebido y compuesto en cuartetas no desde 1589 gracias a Lobo Lasso de la Vega, sino, por lo pronto, desde Juan del Enzina (véanse, por ejemplo, sus romances "Una sañosa porfía" y "Por unos puertos arriba" en el Cancionero musical de Palacio).

Pero vale la pena ver más de cerca el aspecto prosódico-melódico. Estoy convencido de que una de las razones de la falta de claridad en este terreno es que no existe una buena edición a la vez

tinuó apareciendo como unidad métrica y semántica la pareja de octosílabos, aunque con frecuencia tales unidades se sumaran en cuartetas"; p. 220, nota: "La cuarteta como unidad de composición no llegó a establecerse de propósito hasta Gabriel Lobo Lasso de la Vega, 1589, según puede verse en S. Griswold Morley", etc.; y p. 272: "Se estableció [en el siglo xvn] la cuarteta como unidad de composición en lugar de la pareja de versos".

9 Baehr resulta así aún más mecánico y dogmático y desorientador que sus fuentes. He aquí otra afirmación parecida: "[Durante los Siglos de Oro] la asonancia aguda se tolera tan sólo en romances satíricos o religiosos" (nótese el verbo tolerar, nótese el tan sólo). T. N. T. se limita a decir (p. 220, nota) que las terminaciones agudas son mucho menos frecuentes que las llanas (rasgo propio, se me ocurre comentar, del "genio" de la lengua castellana). Es verdad que en la p. 272 añade: "se siguió evitando con señalada determinación la rima aguda", y cita la práctica de "Góngora, Lope, Quevedo, Polo de Medina y otros poetas". Yo diré cándidamente que no veo tal determinación. En Góngora, el único caso que he examinado (por más fácil), los romances agudos son casi la tercera parte, lo cual me parece una proporción más que respetable. De ellos, muchos no son ni satíricos ni religiosos. De hecho, uno solo de los religiosos es agudo, y varios de los satíricos, comenzando con el primero propiamente tal (núm. 7, "Érase una vieja / de gloriosa fama...") y terminando con el último (núm. 94, "Todo se murmura, / y la culpa toda...") son llanos.

10 "Por no tener en cuenta esta distinción, Bello (Ortologia, 358) creyó ser consustancial al romance la cláusula métrica tetrástica, sin reparar en que medio teatro español del Siglo de Oro se evade de tal norma" (EcharRi, loc. cit.). 
literaria y musical, acompañada de un buen estudio, de todos los romances de los siglos xv y xvi cuya música se conserva. A mí, por cierto, me gustaría acometer la tarea. Por ahora me limitaré a criticar el siguiente párrafo de BAEHR, p. 207: "Las melodías más antiguas [de romances] se disponen en unidades de dieciséis notas [dos octosílabos]; así en F. Salinas. Existen también períodos musicales de treinta y dos notas [cuatro octosílabos], sobre todo en el Cancionero de Palacio, pero no se da el caso de ocho notas; esto comprueba que la unidad de composición y contenido en el romance no es el octosílabo, sino que se constituye por uno o dos versos de dieciséis sílabas".

Todo esto está dicho de manera muy torpe. El lector desprevenido (como suelen serlo los sufridos estudiantes de Letras a quienes fundamentalmente se destinan manuales como el de Baehr) entiende que el De musica de Francisco Salinas, publicado en 1577, es el documento musical más antiguo que hay para el romance; entiende que se conservan muchas melodías antiguas para versos largos de dieciséis sílabas (las transmitidas por Salinas serían sólo un ejemplo), aunque también -en algunos casos, cabría suponer- hay melodías para cuartetas enteras, "sobre todo" en el Cancionero musical de Palacio (como si en las otras fuentes, los vihuelistas y polifonistas del siglo xvi, hubiera un poco de todo: melodías para dieciséis sílabas y melodías para treinta y dos). Todo lo cual es falso.

Comencemos con la afirmación de que "no se da el caso de ocho notas". Lo que ocurre es exactamente lo contrario: el caso que no se $d a$ es el de dieciséis notas. La melodía (única) que nos ha transmitido Salinas cubre sólo un octosílabo ${ }^{11}$. Salinas, que no es un folklorista, sino un teórico musical, cita esa melodía para ilustrar de la manera más simple, la más clara e inteligible para sus lectores, un ritmo que consiste en la alternancia del compás de $3 / 4$ con el de 6/8: dos negras y dos corcheas en el primero, negra-corchea y negra-corchea en el segundo ${ }^{12}$. La melodía, o el ritmo diríamos mejor, siempre el mismo, figura tres veces con su pentagrama y sus

11 Se seguiría, entonces, que "la unidad de composición y contenido en el romance", como dice Baehr, si es el octosilabo. Pero me guardaré mucho de hacer semejantes afirmaciones. Me apoyo, para lo que digo de Salinas, en el sólido estudio de Isaber Pope, "La melodía del Conde Claros", NRFH, 7 (1953), 395-402.

12 Negras y corcheas son "traducción" de las semibreves y mínimas que usa Salinas en su notación. También la indicación de compás (que falta en Salinas) es traducción moderna. Por cierto, la primera vez que cita Salinas la melodía escribe, para mayor claridad desde su punto de vista (la explicación de ese ritmo musical, tan genérico), tres semibreves (= negras) en el primer "compás" (el de 3/4), no sin advertir que en el canto mismo la segunda o tercera de ellas se "resuelve" en dos mínimas (= corcheas): “... secunda longa aut tertia resolutis". 
notas: la primera vez aparece sin letra, la segunda con el verso "no podía reposar" (del romance de Conde Claros, "Media noche era por filo"), y la tercera con dos versos de otro romance, "Retrayda está la infanta, / bien assí como solía". Dos versos, sí, pero sólo para que quede bien claro que el ritmo es $3 / 4,6 / 8,3 / 4,6 / 8 \ldots$ indefinidamente. $O$ sea: la continuación indefinida es lo que asegura el ritmo, pero la melodía misma abarca sólo ocho sílabas, que constituyen la unidad rítmica: la música de "bien assí como solía" es exactamente la de "Retrayda está la infanta" y la de "no podía reposar". Es, dice Salinas, una melodía superconocida ("cantus notissimus est"). No tiene nada que ver con las que se les ponen a los romances, viejos y nuevos, en las cortes y capillas musicales desde tiempo de los Reyes Católicos, melodías refinadas, originales, con acompañamiento instrumental o coral, conocidas sólo de una minoría ${ }^{13}$. Es la tonada popular y callejera, la de los ciegos, la architradicional y archielemental ("cantus antiquissimus et simplicissimus est"). Con esa melodía, dice una vez Salinas, se cantan muchos de los romances españoles ("Ad quem cantum Hispani plurimos ex his quos Romances vocant, enuntiare solent"), pero otra vez, y en la misma página, afirma que vale para todos (con ese ritmo "omnes compositiones Hispaniae, quibus historiae seu fabulae narrantur, ab antiquis nostris canebantur") ${ }^{14}$.

Una vez hecha esta distinción entre la melodía-ritmo única para todos los romances cantados por el pueblo y el rico conjunto de melodías que los músicos fueron componiendo para muchos romances de muchos tipos, hay que decir que las melodías de éstos abarcan

13 "El texto más viejo que se conoce de [un fragmento del Conde Claros] se encuentra en el Cancionero musical de Palacio, de fines del siglo $\mathrm{xv}$, con música de Juan del Enzina... Su melodía no tiene nada que ver con la sencillísima tonada del romance citado por Salinas. Es música sabia, obra de un artista muy versado en el arte contrapuntístico de la época. Se compone la melodía de cuatro frases distintas [no de una sola], en cada una de las cuales se acomoda un octosílabo" (IsAbel Pope, art. cit., p. 397).

14 La elementalidad y tradicionalidad del ritmo de los romances viejos, tipificados por el de Conde Claros, fue lo que incitó a cinco vihuelistas, anteriores todos ellos a Salinas - Luys de Narváez (1538), Alonso Mudarra (1546), Enríquez de Valderrábano (1547), Diego Pisador (1552) y Luys Venegas de Henestrosa (1557) - a lucirse con sus virtuosistas "diferencias" o variaciones sobre el "tenor" del Conde Claros, o sea el tema simplicísimo de un octosílabo, repetido $n$ veces como basso ostinato o pedal mientras la arquitectura sonora -varía (22 veces en el caso de Narváez, 37 en el de Pisador). Esas "diferencias" fueron uno de los productos con que España se incorporó a la amplia corriente de la música europea renacentista. Cuenta Salinas "que en la corte del papa Paulo III escuchó a su amigo Francesco da Milano, compositor y tocador de laúd, improvisar en su instrumento, tomando como «tenor la melodía del Conde Claros" (Isabel Pope, p. 399). El nombre técnico del ritmo ilustrado por Salinas es hemiola. 
siempre una cuarteta. Luys de Narváez, en nota a sus composiciones con letra de "Ya se asienta el rey Ramiro" y "Paseábase el rey moro", advierte: "Por ser la letra destos romances muy conocida, no se pone aquí sino los quatro pies primeros del romance, porque $d e$ quatro en quatro pies ${ }^{15}$ se han de cantar" (Los seys libros del Delphin de muisica de cifra para tañer vihuela, Valladolid, 1538, fol. $66)$. Y esto vale para la Serranilla de la Zarzuela, para los romances del Cancionero musical de Palacio, para los de los vihuelistas y polifonistas $\mathrm{y}$, que yo sepa, para todos los demás del siglo xvI ${ }^{\mathbf{1 6}}$.

Finalmente, no es verdad que la "tendencia hacia la disposición en cuartetas" comience a aparecer "a fines del siglo xv". Aparte de que en la mayoría de los romances viejos abundan, por la naturaleza misma de la frase castellana, largas tiradas separables en grupos tetrásticos ${ }^{17}$, el romance escrito más antiguo que se conoce, "Estáse la gentil dama" (circa 1421), está hecho visiblemente en cuartetas. Visiblemente, digo: la foto del manuscrito, publicada en $R F E, 14$ (1927), p. 140, muestra unas rayas después de los versos $4,12,20$ y 24 , y lo mismo pudiera haberlas después del 8 y del 16 .

Paso ahora al estudio de ciertas observaciones hechas por cuatro preceptistas del Siglo de Oro. $Y$ en primer lugar, las que se refieren al tamaño de los versos.

Dice Rengifo en su Arte poética española de 1592 (pero cito por la ed. de Madrid, 1644): "Ai nueue maneras de verso: de redondilla mayor, y su quebrado; de redondilla menor; italiano, y su quebrado; esdrúxulo, y su quebrado; de arte mayor; finalmente,

15 "Pie" es lo mismo que verso; "pie de romance" significa verso de ocho sílabas (tal como "pie quebrado" significa verso de cuatro). La designación "pie de romance" para el "dieciseisílabo", que aparece en Nebrija (T. N. T., p. 44), no fue de uso común.

16 La melodía de "Por mayo era, por mayo" (Cancionero musical de Palacio, núm. 85) es algo más complicada. A veces, como hemos visto (supra, pp. 343-344, nota 4), hay encadenamientos: se cantan sucesivamente los versos 1-4, 3-6, 5-8, etc., pero la melodía cubre siempre 32 sílabas. Lujosamente, tres de los cuatro romances de Luys Milán (1535) -el de Durandarte, el de Baldovinos y el de "Con pavor recordó el moro" (donde están los versos famosos "mis arreos son las armas, / mi descanso es pelear") - constan de dos "partes", cada una de las cuales abarca los consabidos cuatro octosílabos.

$1 \tau$ Lo cual hace que cuando se ponen en música, durante el Renacimiento, no existan grandes problemas de acomodo de la letra. A veces, claro, quedará pendiente el sentido. Pero es lo que sucede ya en el romance "Hablando estaba la reina", publicado por G[Aston] P[ARTs] en Ro, 1 (1872), 373-378. Era obviamente un romance cantado (al francés que copió la letra no le interesaba el accidente que en 1491 le costó la vida al hijo del rey de Portugal), y entre cuarteta y cuarteta hay un patético estribillo, pero en una de las cuartetas la frase se queda colgando. En cuanto a las toneladas de romance que hay en el teatro español, yo apostaría que un 75 por ciento, cuando menos, es divisible en cuartetas. 
verso latino imitado" (p. 12). Excluyamos el último, que, sobre ser un cajón de sastre, siempre fue una rareza ${ }^{18}$. Excluyamos también el esdrújulo y su quebrado, que no son sino variedades de otros metros ${ }^{19}$. Quedan cuatro versos autónomos, que son el de redondilla menor (hexasílabo), el de redondilla mayor (octosílabo), el italiano (endecasílabo) y el de arte mayor; y dos no autónomos, que son el tetrasílabo (subordinado al octosílabo) y el heptasílabo (subordinado al endecasílabo) ${ }^{20}$.

Luys Alfonso de Carvallo, en su Cisne de Apolo, de las excelencias y dignidad y todo lo que al Arte poética y versificatoria pertenece, los métodos y estylos que en sus obras deue seguir el poeta, el decoro y adornos de figuras que deuen tener y todo lo demás a la Poesia tocante, significado por el Cisne, ynsignia preclara de los poetas, Medina del Campo, 1602 (pero cito por la ed. de Madrid, 1958 , t. 1, pp. 184-192, y t. 2, pp. 126-127), reconoce sólo estas seis maneras de versos: el redondillo quebrado o minimo (tetrasílabo), el redondillo menor (hexasílabo), el redondillo entero (octosílabo), el eroyco (endecasílabo), el quebrado del heroico o eroyco menor (heptasílabo) y el de arte mayor ${ }^{21}$. El redondillo menor, dice, "sirue a cosas humildes, como para donayres y passatiempos, letras y cosas de niñerías"; el redondillo entero sirve fundamentalmente "a las cosas medianas"; el endecasílabo sobre todo "a cosas altas y famosas", y el de arte mayor "a cosas deuotas y exemplares y doc-

Is "Del verso latino imitado en español" se ocupa Renglfo en las pp. 18. 19. Da ejemplos de dístico elegiaco y de "odas de sáphicos y adónicos" (cuartetas de 11-11-11-5, sin rima), y añade con cándido optimismo: "Desta manera se pueden componer versos dímetros, senarios, iámbicos, asclepiadeos, glicónicos, faleucos, hendecasílabos [catulianos, se entiende], alcmamios y otros géneros que vsan los poetas latinos".

19 El ejemplo que da RENGiFo en la p. 17 ("Espíritu profético / el gran Bautista tuuo, y vida angélica") es de heptasílabo y endecasílabo. (Sobre los versos esdrújulos, de los cuales se burló Cervantes, véase EcharRI, pp. 230-236) .

20 No menciona Rengifo el pentasílabo ("adónico") sino de paso, como elemento de la oda sáfica (supra, nota 18).

21 Carvallo, que evidentemente tiene a la mano su Rengifo, no deja de mencionar el verso "exdrúxulo" (con este ejemplo: "Estamos en las almas descuydándonos, / en vicios embolcándonos"), y en cuanto al "verso latino imitado", prefiere cuerdamente decir las cosas de manera muy general: "...y los más que los buenos poetas del latino y otras lenguas puedan imitar", según sus fuerzas, con lo cual no sólo evita la enumeración de asclepiadeos y glicónicos y faleucos, sino que abre la puerta a las imitaciones de versos usados en otras lenguas. Se detiene, de hecho, en el "verso francés", o sea el alejandrino, compuesto de dos heroicos menores (de manera que "calça catorze puntos"), no sin aclarar que este verso "bien poco se usa, sino para ostentación de varias poesías, como hizo Gaspar Gilpolo" -que en efecto lo emplea con ese nombre y esa finalidad, y que es el único ejemplo que debe haber conocido Carvallo (cf. T. N. T., pp. 205-206). 
trinas subidas, como hizo luan de Mena y Lorenço Suárez de Chaves". Y el tetrasílabo y el heptasílabo ¿a qué sirven? De ellos, contesta Carvallo, "no se haze ninguna compostura sin yr en compañía de otros versos": el primero funge como quebrado de los octosílabos, el segundo como quebrado de los endecasílabos. No tienen, desde luego, la independencia del hexasílabo, el cual "no admite en vna copla compañía de otros versos".

El docto Gonzalo Correas, en su Arte grande de la lengua castellana, de 1626, reconoce nueve tipos de versos, pero no son exactamente los nueve de Rengifo: "Los jéneros de versos qe hasta agora conozemos i usamos son nueve, desde 4 sílabas hasta 12: verso de 4 sílabas, qe llaman pie quebrado; verso de 5 sílabas, qe en griego i latín es adónico; verso de 6 sílabas, de redondilla menor; verso de 7 sílabas, menor de lira i canzión; verso de 8 sílabas, de redondilla mayor, qe llaman arte real, i son las redondillas naturales de España; verso de 9 sílabas, qe se halla i usa en coplillas i cantares; verso de 10 sílabas, qe también se usa en cabezas de villanzicos i cantares; verso de 11 sílabas, heroico, de octava rima $\mathrm{i}$ soneto; $\mathrm{i}$ verso de 12 sílabas, de arte mayor" (cit. por EcharRr, p. 184). De estos nueve ${ }^{22}$, sólo tienen categoría o función precisas cuatro (los mismos que en Rengifo y en Carvallo) : el hexasílabo, el octosílabo, el endecasílabo y el de arte mayor. El tetrasílabo se mezcla como pie quebrado con el octosílabo, el pentasílabo es ingrediente de las seguidillas (cita en Echarri, pp. 212-213) y el heptasílabo sirve como verso "menor" en canciones petrarquistas; y finalmente, las funciones del eneasílabo y del decasílabo son esporádicas y modestas.

De estos cuatro metros que los tratadistas consideran operantes y autónomos, habría que quitar todavía el verso de arte mayor, que ya no era operante, pues "a partir de 1575 -como observa EcharRI, pp. 186-187, aunque sin aclarar por qué a partir de ese año- se puede decir que este metro, elogiado por unos en forma casi ditirámbica, menospreciado por otros, desaparece de la vista", si bien "los preceptistas... nos siguen hablando de él, como si estuviera vigente, o tal vez como si esperasen su resurgimiento". Quedan así únicamente el hexasílabo, el octosílabo y el endecasílabo.

Faltaba todavía algún tiempo para que se hicieran romances de

22 Correas no incluye aquí el esdrújulo, aunque se ocupa de él en otro lugar, donde dice que el esdrújulo "o resbaladizo se usa en las liras i canciones", y que sus dos últimas sílabas son "tan corridas $\mathrm{i}$ arrebatadas, qe en cuanto a la medida es lo mesmo qe antes, qe no se cuentan las dos más de por una" (cit. por Echarri, p. 237, nota). Esta explicación procede seguramente de Rengifo, el cual había dicho (p. 17) que la palabra esdrujjulo viene de un verbo griego "que significa lo mismo que en romance correr o resvalar, y quadra muy bien a este género de versos, porque acaban con el acento en la antepenúltima, y parece que desde aquella sílaba hasta el fin van corriendo". 
once sílabas, pero los de seis estaban a la vista, sobre todo en el Romancero general de 1600 (cf. T. N. T., pp. 218-219 y 221). Así, Correas puede decir que el hexasílabo "se inuentó primero para hacer endechas, pero ya sirue para romanzes y villancicos, de los cuales andan muchas y muy graciosas sonadas" (cit. por ECHARRI, pp. 207-208) . (Carvallo, como se ha visto, había asignado al hexasílabo "donayres y passatiempos y cosas de niñerías", aunque sin referirse expresamente a romances) .

Quien ha leído en T. N. T., p. 209, que la anacreóntica heptasilábica de Gutierre de Cetina, "De tus rubios cabellos, / Dórida ingrata mía...", anterior a 1554, es un "fresco y gracioso romancillo", podrá sorprenderse de la ignorancia de los tratadistas de métrica del Siglo de Oro. Aquí se impone una reflexión. Ellos no disponían de toda la información que está al alcance de los modernos. Ciertamente, ni Carvallo ni Correas podían ignorar el seductor romancillo hexasilábico de Góngora, "La más bella niña / de nuestro lugar...", pero sin duda los dos desconocían sus romances heptasilábicos, el más antiguo de los cuales (núm. 40, "Moriste, ninfa bella..."), aunque escrito en 1594, no se imprimió sino en la cuarta década del siglo xvn, cuando se hicieron las ediciones de sus obras. El historiador de la métrica debiera tener esto muy en cuenta. Pondré un ejemplo. Dice BaEHR, p. 91, que en 1665 Lorenzo Matheu y Sanz tradujo el Spill de Jaume Roig "en 16,000 pentasílabos [Castellanos]", cantidad en verdad más que suficiente para asegurarle carta de ciudadanía y plena autonomía a este verso. Sin embargo, si Baehr aclarara que la tremenda labor de Matheu y Sanz quedó inédita hasta que en 1936 la editó el erudito R. Miquel i Planas, el lector entendería mejor en qué sentido tan limitado pertenece a la "historia" del pentasílabo español esa traducción. Es verdad que en esta historia entra también un coro de 72 versos sin rima de la Nise laureada de Jerónimo Bermúdez, obra dada a la imprenta en 1577 ( $T$. N. T., pp. 212-213) ; pero, si no hubiera otros indicios, bastaría éste para concluir que las Tragedias de Bermúdez no tuvieron lectores en los Siglos de Oro.

Volviendo al heptasílabo, ni Rengifo ni Carvallo ni Correas tuvieron barruntos del auge medieval de este metro "como verso corto autónomo", que "se halla en las 686 redondillas de los Proverbios morales de Sem Tob" (BAenr, p. 99). Tampoco pudieron conocer la mencionada anacreóntica de Cetina, que no se publicó hasta 1895 . De esta manera, Góngora, que tampoco pudo conocerla, resulta con sus cuatro romances heptasílabos (núms. 40, 46, 47 y 58) un auténtico innovador ${ }^{23}$. En cuanto a las odas en heptasílabos sueltos de

23 El experimento de Cetina "no tuvo probablemente ningún efecto", dice BaEHR, p. 100. Et pour cause. 
Francisco de la Torre ${ }^{24}$, no se imprimieron hasta 1631. Rengifo, Carvallo y Correas no pudieron haber leído sino las poesías heptasilábicas de Jerónimo Bermúdez ${ }^{25}$, pero, como acabo de decir, no dan muestras de haber leido las Tragedias de este autor.

"El más destacado, el más completo y acaso el menos leído" de quienes escribieron sobre métrica en el Siglo de Oro es el monje cisterciense y gran personaje Juan Caramuel y Lobkowrtz (16061682) (Echarri, p. 87) ${ }^{26}$. A él, y no a Rengifo, le corresponde "el primer puesto entre nuestros preceptistas" (ibid., p. 72). Su Primus calamus es una verdadera "enciclopedia métrica" en dos volúmenes: la Metametrica (1663), "que se diría escrita por un cerebro genial, pero desequilibrado”, y la Rhythmica (1665; 2: ed., 1668), "escrita con más lucidez", y para la cual se inspiró "sin duda en Rengifo, pero aventajándole con mucho en todos los sentidos" (ibid., p. 88) ${ }^{27}$. Caramuel mismo declara "que compuso su libro en plena juventud" (ibid,, p. 92). En la Rhythmica cita a los poetas que estaban de moda hacia 1630: Lope y Góngora, desde luego, pero más aún Cáncer, Esquilache, Paravicino y otros a quienes hoy sentimos de segunda o tercera fila. En unas epístolas "insertas al final, que el mismo Caramuel confiesa fueron escritas mucho tiempo después", menciona ciertos libros de poesías que antes no había consultado, entre ellos los de fray Luis de León y Francisco de la Torre, publicados ambos por Quevedo en 1631 (ibid., p. 91). No cita, al parecer, a Garcilaso ni a Herrera (ibid.), y "desconoce... los ensayos alejandrinos de Gil Polo, Espinosa, etc." (ibid., p. 129, nota 29) ${ }^{28}$. A cambio de esto, Caramuel - como ya habian hecho Rengifo

24 No "la oda", como dice T. N. T., p. 210 (copiado por BAEHr, p. 100), refiriéndose a la 6 del libro I, "Daphnis, estas passiones..."; en el mismo metro está la 5 del mismo libro, "Alexis, ¿qué contraria...?" (Francisco de la Torre fue, además, el más sistemático cultivador del hexasílabo. Las diez "endechas" que integran el libro III de sus Obras están en este metro; todas son redondillas menores, salvo la segunda, que es un romance).

25 Véase T. N. T., pp. 209-210. Hay cuatro en la Nise lastimosa y una en la Nise laureada. La designación de "medias rimas" que les da Bermúdez es muy clara: también Rengifo, Carvallo y Correas sienten el heptasílabo como una especie de "medio endecasílabo". En cambio, en Francisco López de ÚbEDA "media rima" designa unas coplas aconsonantadas de seis octosílabos y dos endecasílabos (La picara Justina, ed. J. Puyol, Madrid, 1912, t. 2, p. 115).

26 El menos leído, sobre todo. T. N. T. no hace más que mencionarlo en la introdución, p. 19 (con errores); BAEHr lo cita seis veces, las seis a través de Echarri.

27 A juzgar por la información de Palau. el Primus calamus es obra bastante rara. "No se perdería nada con hacer de [la $R$ hythmica] una reimpresión moderna, ya que pocos documentos de la época alcanzan a ofrecernos tan sabrosos informes y noticias sobre las corrientes literarias que dominaban en el siglo en que vio la luz" (Echarri, p. 91).

28 Si desconoce el de Gil Polo, quiere decir que desconoce también el Cis- 
y Carvallo- prodiga los versos propios, porque "lo mismo componía en castellano que en latín, en griego, en inglés o en alemán" (ibid., p. 89). Echarri llama la atención sobre "los ejemplos de propria minerua" con que "esmalta su Ritmica" (ibid., p. 170) ${ }^{20}$.

Dice Caramuel (cit. por Echarri, p. 108, nota 35): "Versus est oratio determinatum numerum syllabarum postulans. Alii has numerant aliter; ego a prima ad eam usque inclusive, cui ultimus accentus insidet, progredior... Si quid post ultimum accentum adjacet, quidquid grammatice fiat, rhythmice numerum syllabarum non auget". O sea que si hay siete sílabas "rítmicas" en el verso "Los rayos le cuenta al sol", también hay siete en "Las redes sobre el arena", y siete también en "Nace limpia y odorífera", aunque en este último verso las sílabas "gramaticales" sean nueve ${ }^{30}$. Para Caramuel, éstos no son octosílabos, sino heptámetros, y los que nosotros llamamos heptasílabos y endecasílabos él los llama hexámetros y decámetros, y así los demás.

Desde el punto de vista de su longitud, los versos españoles son ocho, que van del trimetro, "qui habet ultimum accentum in syllaba tertia", al decámetro, "qui habet ultimum accentum in decima" (ECHARRI, p. 128) ${ }^{31}$. Caramuel los ejemplifica de manera muy gráfica, cercenándole sílaba tras sílaba a un verso del Príncipe de Esquilache, "después que son la luz, que no reposa":

$\begin{aligned} \text { Después que son la luz, que no reposa } & \text { (decámetro) } \\ \text { Pues que son la luz, que no reposa } & \text { (eneámetro) } \\ \text { Que son la luz, que no reposa } & \text { (octómetro) } \\ \text { Son la luz, que no reposa } & \text { (heptámetro) } \\ \text { La luz, que no reposa } & \text { (hexámetro) } \\ \text { Luz que no reposa } & \text { (pentámetro) } \\ \text { Que no reposa } & \text { (tetrámetro) } \\ \text { No reposa } & \text { (trimetro) }\end{aligned}$

ne de Apolo de Carvallo, que lo menciona (cf. supra, nota 21). El ensayo alejandrino de Espinosa no se imprimió hasta 1896 (cf. infra, p. 379, nota 67).

$29 \mathrm{Al}$ parecer, estos ejemplos "de propria mineria" suelen figurar anónimos. EcharRI, pp. 194-195, sospecha que son suyos los versos presentados (sin éxito) "en un certamen de Salamanca en 1629, con motivo del natalicio del príncipe Baltasar [Carlos]", que Caramuel cita atribuyéndolos a "quídam ingeniosus Poëta". El dato es de interés, porque demostraría que ya hacia 1629 estaba metido Caramuel en sus lucubraciones métricas.

30 En cambio, Carvallo (Cisne de Apolo, t. 1, p. 191), contando "a lo gramatical" y no "a lo rítmico", decía que "el exdrúxulo mayor tiene doze syllabas, y el quebrado o menor, ocho" (en vez de 11 y 7 , respectivamente).

31 En cuanto al hendecámetro (= verso de arte mayor), Caramuel "coincide con Carvallo y los otros en la apreciación de este metro como doble exasílabo" (Echarri, p. 193). Hay también dodecámetros, pero no en España ("quibus numeris licet non utatur Hispanus, delectatur Gallus et Germanus", ibid., p. 129) . 
"Muy ingenioso y excesivamente infantil", sonríe Echarri (p. 185). Se le escapan a Caramuel no pocas variedades de ritmos. "En cambio, le ha brotado de las manos, sin darse cuenta, un metro nuevo o al menos desconocido hasta el presente. Ha bastado suprimir al heroico su primera sílaba para hacer que saltara limpio, movidísimo, centelleante, este hermoso decasílabo: «Pues que son la luz que no reposa». Es un verso completo; de una armonía sugestiva" 32 .

Esto es lo extraordinario de Caramuel: a su incontenible afán especulativo le venía muy chiquita toda la producción poética española existente ${ }^{33}$. Francisco López de Úbeda, esa avis rara, ese otro loco, ha hecho sonetos octosílabos (el único, que se sepa: cf. T. N. T., p. 252). Y Caramuel, que no deja de acudir a los versos de la Picara (Echarri, p. 236, nota 34), debe haberse dicho que muy bien, pero que por qué no hacer también sonetos de siete, de seis, de cinco sílabas. "Cur non? Sicut in maioribus, ita et in minoribus poterunt consonantiae disponi; consonantiarum enim fluxus a nulla carminum quantitate aut mensura dependet" (ibid., p. 170) . No contento con tan irrefutable razonamiento, Caramuel pone manos a la obra "y trae ejemplos de sonetos de ocho, siete y hasta seis sílabas" (ibid., p. 248) ${ }^{34}$. Y es bien consistente en sus especulaciones. "¿Se pueden hacer liras en metro menor? Innecesario decir que su respuesta es afirmativa" (ibid., p. 255). ¿Y décimas en endecasílabos, o en versos de arte mayor? ¡Por supuesto que sí! El núcleo mismo del pensamiento especulativo de Caramuel, la teoría "repetidamente defendida a lo largo de su libro", es "que las combinaciones adecuadas para un metro son válidas y aplicables para todos los demás, sean del ritmo que fueren, y con independencia del número de sílabas" (ibid., p. 170).

Lo mismo tenía que valer para el romance. "Admite Caramuel romances de ocho, siete y cinco sílabas ${ }^{35}$. Y como la asonancia no es cualidad privativa de los versos cortos, no ve inconveniente en que se aplique también al endecasílabo. Así es como llega al romance heroico" (ibid., p. 205). Asi, o sea: por vía especulativa, me-

32 Para hacerle una pequeña broma a Echarri, se me ocurre poner el "nuevo o al menos desconocido" verso de Caramuel entre uno de don Juan Manuel y otro de doña Gertrudis Gómez de Avellaneda, que encuentro en T. N. T., pp. 76 y 365: "por pobréza, núnca dèsmayédes", "pues que són la lúz que nò repósa", "y tu sómbra muéstras èn el sól". Más en serio: ¿no es igualmente nuevo y limpio, etc., el eneasílabo "Que son la luz, que no reposa"...?

33 Con todas sus lagunas, antes señaladas, Caramuel es evidentemente el metricista del Siglo de Oro que cita mayor número de poetas. Es, por cierto, el único que habla de la silva (Echarri, p. 258).

34 "Probablemente suyos", añade Echarri. ¿Por que "probablemente”? ¿De dónde pudo haberlos tomado?

35 ¡Raro! ¿De seis no? ¿Y de nueve? ¿Y presenta ejemplos de romances pentasilabos? En fin, si así es, no sería la única laguna de mi Catálogo. 
diante su contundente "Cur non?", al que siguen, por lo demás, "muchos y largos ejemplos de romance heroico"'. No dice aquí Echarri si esos ejemplos son "de propria minerva". Es de suponer que sí. Según se verá en mi Catálogo, para 1665 se habían compuesto ya no pocos romances de once sílabas. Pero la Rhythmica se escribió evidentemente mucho antes de 1665. Sus lectores españoles (pocos, según parece) ${ }^{36}$ deben haber pensado que en este punto concreto el erudito obispo había descubierto el Mediterráneo. En todo caso, es un hecho que es él el único tratadista del Siglo de Oro que habla del romance "heroico".

Después de decir que "Así es como llega [Caramuel] al romance heroico", añade Echarri: "...por el que tal adversión [sic] sentía don Marcelino", y en nota hace unas observaciones muy sensatas, diciendo, en sustancia, que tan buena poesía se puede hacer en esa forma poética - desacreditada a los ojos de Menéndez Pelayo ${ }^{37}$, pero muy bien acreditada siglos antes- como en cualquier otra, con tal que haya esa armonía de pensamiento y expresión, de mundo y lenguaje, o como queramos decirlo, que hace que la poesía sea poesía. No la hay, probablemente, en los romances heroicos de Caramuel, que a todas luces no era poeta, de manera que los ejemplos que Echarri aduce contra Menéndez Pelayo no son del obispo, sino de García de la Huerta, Martínez de la Rosa iy José María Pemán! De cualquier modo, su ilustración y defensa del romance heroico es justa.

Echarri parece estar fascinado por ese "loco genial" (p. 89) que fue Caramuel, inventor por vía especulativa del romance heroico. Ya se ha visto cómo aplaude su decasílabo (o eneámetro) "Pues que son la luz, que no reposa”. Más adelante (pp. 193-194) elogia otro acierto a que llegó el obispo "siguiendo su técnica combinatoria": "Así como llegó al decasílabo... por supresión de la primera sílaba en el heroico italiano, así llega..., por agregación de otra

36 Las elegías decámetras y el romance eneámetro de Álvarez de Velasco (infra, p. 433, $\$ 136$ ) son verdaderamente excepcionales. Hay que tener en cuenta que el Primus calamus, como la mayor parte de la abundantísima producción de Caramuel, está escrito en latín, y que no se imprimió en España, donde no había imprentas capaces de hacerlo: la Metametrica se publicó en Roma y la Rhythmica en Campania (que fue, según la Enciclopedia Espasa, uno de los varios obispados que se asignaron sucesivamente a Caramuel) .

37 La crítica restrictiva y regañona de don Marcelino recuerda en este punto particular la de Hermosilla. Cuando Meléndez Valdés dijo que el romance era "metro a propósito para toda clase de poesías, incluso odas" (si buenas o malas dependía, claro, del poeta), Hermosilla se lanzó a contradecirlo (Hurtado y González Palencia, Hist. de la lit. esp., 6a ed., Madrid, 1949, pp. 745746) ; y cuando la Academia convocó a un concurso de poemas de tema heroico en romance endecasílabo (infra, Catálogo, $\$ \$ 202$ y 203), "Hermosilla hubiera preferido la acostumbrada octava real" (T. N. T., p. 296, nota 8) . 
sílaba", a un dodecasílabo de $7+5$ "que después, popularizado por Balart en su Dolores, ha tenido gran aceptación". Los endecasílabos "Formando la abundancia de los ríos / mayor diluvio y valles siempre fríos" quedan convertidos en:

Formando la abundancia de muchos ríos mayor diluvio y valles mucho más fríos.

Se me ocurre comentar, por una parte, que un pareado igual, con la misma acentuación y todo, existe ya en una hermosa composición del llamado Cancionero de Upsala (1556):

Dezilde al cavallero que non se quexe: que yo le doy mi fe que non le dexe.

$\mathbf{Y}$ por otra parte, pienso que si los versos manipulados por Caramuel hubieran sido éstos (anónimos): “Zambúllense las ranas por la charca / al ver que acuden hombres en la barca", dando como resultado

Zambúllense las ranas por esa charca al ver que acuden hombres en una barca,

el invento le habría parecido detestable, y lo habría contado entre las muchas (e indudables) extravagancias de Caramuel ${ }^{38}$.

En otras palabras, las especulaciones del autor de la Rhythmica me parecen a mí tan interesantes cuando sus resultados son del agrado de Echarri como cuando no es así. Los versos propios con que Caramuel "esmalta" su obra, dice Echarri (pp. 170-171), "más que a despertar nuestro interés contribuyen a confirmarnos en la idea de que [sus] combinaciones estróficas nunca debieran salir del olvido". En lo cual hay una especie de contradicción, parecida a la de Menéndez Pelayo, que después de echar pestes contra todo romance heroico elogia la elección que de él hizo García de la Huerta para su Raquel. Es injusto llamar (p. 170) "el error, el gran error del inefable Caramuel" esa teoría tan suya, de la cual, justamente, han dimanado los ejemplos bonitos.

La "máxima equivocación" de Caramuel, dice en seguida Echarri, "radica en pensar que se pueden mezclar impunemente versos de cualquier número de sílabas o, lo que es lo mismo, de diferente ritmo ${ }^{39}$; que de igual modo que los endecasílabos alternan con los

38 Cabe añadir que los dodecasílabos de $7+5$ no son nada raros en el siglo Xvir, Los practica, por ejemplo, Sor Juana Inés de la Cruz. Cf. T. N. T., p. 262 y nota 31 .

39 Yo no creo que sea lo mismo. Y el propio Echarri, p. 195, nota 52, me da la razón cuando reprende a Andrés Bello por no haber visto que "el trocaico, como los demás ritmos [yo subrayo], no está sometido a un número determinado de sílabas". Pero dejemos esto. 
heptasílabos, pueden hacerlo con los exasílabos, octosílabos, etc." Que si pueden hacerlo se verá adelante (v.gr. la combinación no fea de 8-8-11-11 en el $\$ 78$, o la tampoco fea de 6-6-6-11 en el $\$ 101$ ). Nada de "máxima equivocación", pues. "Heptametra et decametra intexuntur cum gratia", dice Caramuel. Basta matizar un poquito la traducción: "Los octosílabos y los endecasílabos pueden combinarse con gracia”. Otra cosa es que a Caramuel le salgan graciosos los resultados. El ejemplo que pone le parece deplorable a Echarri. Yo lo encuentro más bien risible. Dice el monje y obispo que la Religión Católica es un ama de cría insuperable: Jesús le dio el pecho a San Juan (en la noche de la Cena) y María le dio el suyo a mamar al seráfico doctor San Bernardo. La asociación, a mí, me parece chistosa. Y los versos también:

La Iglesia, mi madre, cría regaladamente a dos:

San Juan al pecho de Dios

y San Bernardo al pecho de María.

Claro que para Caramuel, y para los lectores ad hoc, estos versos no son chistosos. Y, por lo demás, él no los puso en su Rhythmica sólo porque le daban ocasión de celebrar el insigne favor concedido por la Virgen al fundador de la orden del Cister, sino también -o sobre todo- para demostrar que así como había redondillas abba, podía haberlas $a b b A$. "Mal gusto en fondo y forma", declara Echarri. Mezclar versos de ocho sílabas con uno de once es "deplorable mezcla". Yo no lo creo. Tampoco lo creyeron los autores de los nueve romances en cuartetas de 8-8-8-11 que menciono en mi Catálogo. (Véase, al final, la Tabla I) .

No sé si alguno de esos poetas se inspiró en la Rhythmica. Probablemente no. Tampoco sé ${ }^{40}$ hasta qué extremo llegaron las especulaciones de Caramuel en el caso concreto del romance. El hecho es que, con la Rhythmica o sin ella, para 1665 el romance estaba en plena barroquización, y que esta barroquización venía desde los comienzos del siglo. No sólo se habían compuesto ya romances heroicos en cuartetas homeométricas (11-11-11-11 sílabas), sino también muchos romances en cuartetas de versos heterométricos

40 Echarri no lo dice, y dependo por completo de su excelente monografía para mis datos. Cuando tuve en las manos la Metametrica y la Rhythmica, dos librazos, mi interés por estas cuestiones era muy vago y mi tiempo estaba dedicado a otras cosas. Ahora siento no haber tomado apuntes. Pero ¿qué trabajo de erudición (o como se llame esto que estoy haciendo) es exhaustivo? $Y$, aparte de que el afán de exhaustividad suele matar la imaginación, me parece justo que otros investigadores, en el futuro, llenen mis lagunas y superen mis modestas metas. Mi articulo es un acto de fe en ese futuro. Todo él está abierto a la interpretación y a la critica. 
(7-5-7-7, 8-8-8-4, 8-4-8-8, 7-7-7-11, 10-12-10-12, etc.). Parecería incluso que el furor especulativo de Caramuel fuera la respuesta adecuada al furor experimentador de sus tiempos. Si él, como se ha visto, sostenía "que las combinaciones adecuadas para un metro son válidas y aplicables para todos los demás" y "que se pueden mezclar impunemente versos de cualquier número de sílabas", otro tanto habían venido haciendo e iban a seguir haciendo los poetas. La única ley era la formulada por los preceptistas, y por Caramuel mismo (Echarri, p. 169): "Todas las estrofas dentro de un poema deben ser iguales. Cuantos versos lleve la primera estrofa, cuantas escisiones y consonancias tenga, y distribuidas en la misma forma, deben ir las demás estrofas". Es verdad que Caramuel no admite para el romance estrofas o coplas de más de cuatro versos ("Strophae singulae quattuor linearum esse debent", citado por Echarri, p. 205, nota 78 ), pero aquí no hace más que atender a la práctica más corriente y a la doctrina de los tratadistas anteriores a él ${ }^{41}$. Echarri nos dice, además (ibid., nota 80), que los "muchos y largos ejemplos" que da Caramuel de romance heroico están "todos en estrofas tetrásticas", o sea de cuatro versos. En tal caso, habrá que concluir que los poetas que hicieron romances en las estrofas de cinco, seis, siete y ocho versos registradas en mi Catálogo llegaron, independientemente de él, a la misma concepción "loca" de la libertad versificatoria. Cur non...?

Según se verá por los primeros ejemplos de coplas de romance de seis y siete versos que hay en mi Catálogo (Góngora y Lope,

41 "Doctrina no sólo de Rengifo, sino común a todos los tratadistas de la época", era la de que el romance debe ir "muy bien repartido de cuatro en cuatro versos" (EcharRI, p. 202). En las notas de Chacón a los romances de Góngora, estas secciones se llaman "cuartetes"; en el Cisne de Apolo de Carvallo (t. 1, p. 213) se llaman "quartillas". Vale la pena copiar lo que este último dice: "Aduertid que aunque el consonante deue durar todo el romance hasta acabarse, con todo eso va diuidiéndose el sentido de quatro en quatro versos a manera de quartilla, quiero dezir que en cada quatro versos se ha de perficionar el sentido como si fuera vna copla, y no dexarle pendiente para la siguiente quartilla". Ya he dicho antes (pp. 345-346) lo que pienso de la cuestión planteada en 1916 por Morley. El texto de Carvallo demuestra que las artes poéticas se desentendían totalmente de la práctica del Romancero de $\mathrm{Am}$ beres, o de los romanceros de Juan de la Cueva, Timoneda, Sepúlveda, Lucas Rodriguez, etc., o, finalmente, de la práctica de la comedia española. Las artes poéticas se ocupaban sólo del romance lírico, esclavo (o hermano, mejor) de la música. Al posible curioso que le pregunte el porqué de su precepto, Carvallo le contesta: "Porque la principal gracia del romance está en la tonada, y ésta se comprehende y acaua cada quatro versos, y ansí, perficionándose la tonada, no es conveniente que quede el sentido pendiente, porque, ora en repetir el postrero verso, ora en tocar el instrumento, o en descansar el que lo canta, se diuierte el sentido y se pierde el hilo de lo que se va diziendo". (Cf. supra, p. 349, rota 17). 
$\$ \$ 3$ y 6), las porciones excedentes de la cuarteta fueron originariamente estribillos. Valdrá, pues, la pena ver este aspecto de cerca, para tener una idea más clara del proceso de barroquización que va de Góngora a Sor Juana. En el romance núm. 2 de Góngora (infra, § 3), los versos "en la verde orilla / de Guadalquivir" son parte de la copla y a la vez estribillo. En Sor Juana (\$ 116), los versos "¡Ay qué lástima, ay Dios, / ay qué desgracia!" son parte de la estrofa pero no estribillo: los versos 5-6 de las estrofas siguientes van a decir cosas distintas cada vez y, además, el romance así constituido en "sextetos" posee su estribillo aparte.

Ésta es una de las lagunas que noto en los manuales modernos. T. N. T. se refiere ciertamente a los estribillos o "complementos líricos" del romance, del siglo xv al xvn (pp. 155, 220-221 y 273) ${ }^{42}$, pero no dice, de hecho, más de lo que en 1602 dijo Carvallo (Cisne de Apolo, t. 1, p. 216): "[Algunos] romances tienen por el medio ciertas fugas o exclamaciones de vno o dos o de tres quartillas [i.e., de una en una, o de dos en dos, o de tres en tres cuartetas], sin que [en] esto aya limitación ni regla, porque es subordinado a la música, y assí como mejor en ella cayere se deue hazer". El ejemplo que él da, dizque "en lengua antigua", es un romance octosílabo de asonancia $u$ - $a$ en loor de Pelayo, con el siguiente estribillo: " $\mathrm{Al}$ arma, al arma! „Guerra fiera y dura! / ¿Muera la morería y viua Asturias!” (análogo al que Lope de Vega había puesto años antes en un romance también octosílabo, de asonancia $a$ - $a$ : “Dichoso el pastor que alcanza / tan regalado fin de su esperanza!") .

En Góngora estos complementos líricos son todavía, por lo general, bastante sencillos. Los versos que añade (a intervalos regulares o irregulares) son: a) uno de la misma medida y la misma asonancia que las del romance (núms. 46 y 47) ; b) dos de la misma medida, aconsonantados entre sí y en asonancia con la del romance (núms. 3 y 30 ) ; c) dos de medidas varias $(6-10,8-4)$, asonantados entre sí y con la asonancia del romance (núms. 41 y 52); d) dos de medidas varias $(9-5,9-7,5-7,7-5)$, el segundo de ellos con la asonancia del romance (núms. $1,11,45$ y 53 ) ; e) varios versos aconsonantados de tipo italiano (7-11, 11-11, 7-11-11, 7-7-7-11), en correspondencia o no con la asonancia del romance (núms. 5, 13, 47, 50

42 Para el siglo $\mathrm{xv}$, dice que "era sobre todo frecuente el estribillo en los romances hexasílabos", lo cual no me parece exacto. En el Cancionero musical de Palacio, como se ha visto, llevan estribillo los núms. 20, 235 y 346, que son romances hexasílabos, pero también los núms. 254 y 358, que son octosílabos. Y, fuera de este Cancionero, llevan estribillo "Hablando estaba la reina" y "Paseábase el rey moro", que son octosílabos, y no lo lleva la Serranilla de la Zarzuela, que es hexasílabo. Para el siglo xviI, el mismo T. N. T. dice que la práctica de los complementos líricos "decreció", lo cual tampoco me parece muy exacto, por lo que en seguida se verá. 
y 59) ; f) cuartetas castellanas aconsonantadas (núms. 60, 68, 79 y 89). Los demás casos son difíciles de clasificar. En el núm. 75, además del estribillo, se añaden los complementos "amor divino" y "divino amor" (cf. infra, pp. 367-368) ${ }^{43}$. En el núm. 81, el estribillo está hecho de seis versos irregulares, y en el 93 se intercalan a intervalos irregulares cinco diferentes fragmentos líricos. En otros casos, el romance se rompe o se quiebra al final, a menudo con un efecto de gran dinamismo lírico: el núm. 10 termina con siete redondillas; el 52 y el 83, con cantares hexasilábicos asonantados; el 90 y el 92 , con cantares aconsonantados; el 68, el 71 y el 79 (vuelta a lo divino del 68), con episodios dialogados y aconsonantados. $Y$ finalmente, los núms. 62 y 72 son en realidad racimos o ensaladas de romances (tres romances en cada uno, seguidos de una porción "lírica" aconsonantada) ${ }^{44}$.

En Sor Juana, los complementos líricos son a veces sencillos, como "Barquero, barquero, / ique te llevan las aguas los remos!" (núm. 264, t. 2, p. 81), imitado del núm. 41 de Góngora. (Cf. también el primero de los estribillos del núm. 72 de Gróngora y el de Sor Juana, núm. 237, t. 2, p. 33). Pero ya es interesante comparar este de Góngora para un romance de asonancia $o ́$ (núm. 75),

$$
\begin{aligned}
& \text { ¿Quién oyó? } \\
& \text { ¿Quién oyó? } \\
& \text { ¿Quién ha visto lo que yo? }
\end{aligned}
$$

con este de Sor Juana para otro romance en $o ́$ (núm. 294, t. 2, p. 131):

¿Quién oyó? ¿Quién oyó? ¿Quién miró? ¿Quién oyó lo que yo:

que el hombre domine, y obedezca Dios? ¿Quién oyó? ¿Quién oyó lo que yo?

Y éste es todavía un estribillo de los modestos. Las variedades que T. N. T. encuentra en el Romancero general son tortas y pan pintado frente a la costumbre de hacia 1660-1690, la época de Sor Juana y de sus contemporáneos españoles y americanos: Salazar y Torres, León Marchante, Pérez de Montoro, Gabriel de Santillana.

43 No cuento aquí los casos en que los estribillos no son "complementos", sino que pertenecen a la estructura (conceptual y métrica a la vez) del romance: "...y vame tanto mejor / cuanto va de cuerdo a loco" y "hoy son flores azules, / mañana serán miel" son a la vez estribillos y versos 3-4 de cuarteta en los núms. 33 y 58 , y "por el decir de las gentes" es a la vez estribillo y verso final de octeta en el núm. 31 .

44 Hay que agregar que también en las "letrillas" hay complementos líricos, desde un verso ("y digan lo que yo digo", núm. 110) hasta los trece del núm. 171 (donde es preciso hacer algunas modificaciones tipográficas). 
He aquí, por ejemplo, el estribillo de un romance en $\dot{a} \cdot a$, atribuible a Sor Juana (t. 2, p. 285) :

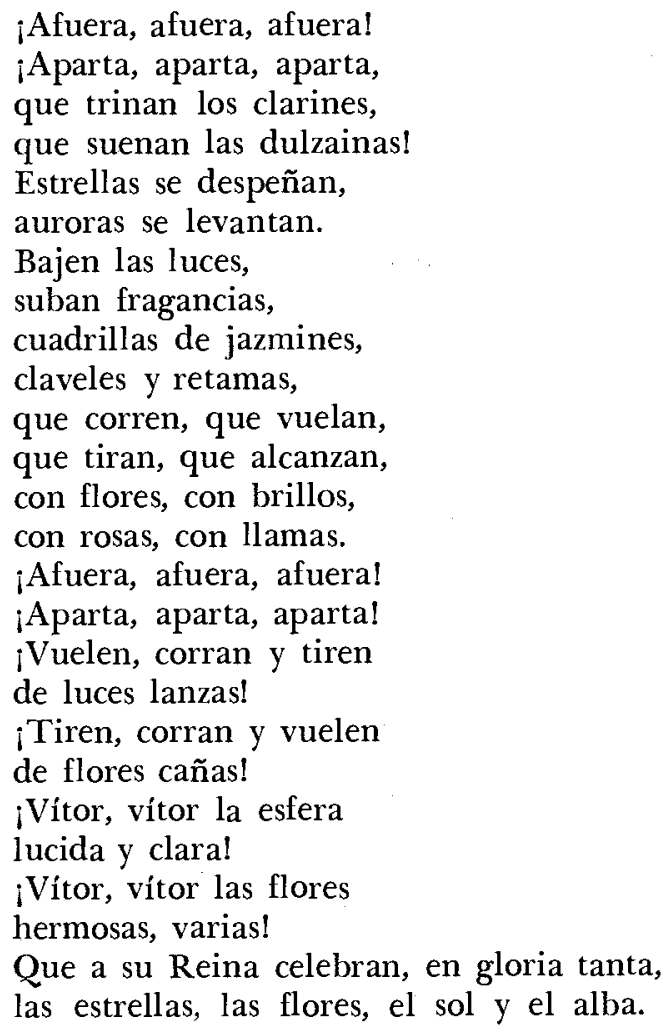

Y he aquí el de un romance en $\dot{o}-a$, de Gabriel de Santillana (A. M. P., $P N$, t. 3, p. 133) :

¡Corred los velos de nácar, serafines, a la Aurora, y cobre en flamantes reflejos la esfera cuanto candor le usurparon las sombras! ¡Ocupen alegres, en salva armoniosa, clarines el aire con dulce lisonja! ¡Rompan, rompan los clarines sus voces armoniosas, declarando al mundo que nace la Aurora, y en gorjeos suaves sus voces se oigan! ¡Repitan, aclamen, celebren, intimen 
con salva gloriosa

que el Alba en sus campos

derrama su alfójar!

Se ha llegado, en realidad, a un momento en que el estribillo, lejos de ser un "complemento" del romance, es su porción de mayor lucimiento ${ }^{45}$, y se comprende que Alfonso Méndez Planearte, en su espléndida antología de Poetas novohispanos, muchas veces haya querido presentarnos esas joyas sin el engaste o la ganga del romance.

Pero este florecimiento o barroquización del estribillo "lírico" no es todo. También están, en Sor Juana y sus contemporáneos, los estribillos "dramáticos", diálogos vivos y rápidos, y las ensaladas de romances que solían hacerse en el octavo villancico de las series de "Nocturnos" compuestas para las vísperas de las grandes solemnidades religiosas. Todo esto cabe en el título que he dado al presente artículo. Entre Góngora y Sor Juana el romance recorrió, en lo formal, un camino inconmensurablemente mayor que el que va de "Estáse la gentil dama" (1421) a "Guarda corderos, zagala", de Góngora (1621). Todas las innovaciones y todos los juegos del Romancero nuevo no fueron sino semilla de lo que vino después, una semilla de la cual, con velocidad pasmosa, brotaron hojas y ramas y flores y frutas. Pero mi artículo, como suele suceder, va a quedarse muy por debajo de su título. Incluir en él, por ejemplo, algún estudio de la evolución de los estribillos -obsérvese cómo los dos últimos que he copiado son, proprio iure, verdaderos romances polimétricos- sería meterse en la selva selvaggia.

¿Cómo era, pues, el romance "artístico" o "lírico" en los momentos en que llegó a las manos de Góngora? Prescindiendo del Romancero viejo, no sólo inmovilizado, sino francamente fosilizado (y prescindiendo también de los romances de Sepúlveda y compañía, que con muy pocas excepciones nacieron tiesos y fósiles, además de prolijos), el romance español tenía en esos momentos los siguientes rasgos:

a) podía estar escrito en versos de ocho, de seis o de siete sílabas

45 Ante ejemplos como estos dos, yo propondría eliminar todo prejuicio hermosillesco y menendezpelayesco ("Ah, sí, esas extravagancias del mal gusto, esas corrupciones vergonzosas, esas lacras de la poesía española") y verlos como expresiones por asi decir "intemporales", desligarlos incluso de su contexto religioso para darles otro menos marcado, llamando al primero "Juego de cañas en celebración de la Naturaleza" (o del Amor Joven, o de la Vida), y al segundo "Instrucciones para el nacimiento de la Luz". Y esto, claro, sin acallar el interés que podamos tener por cualquiera de los aspectos formales que quepa imaginar: anáforas, esquemas distributivo-recapitulativos, antítesis, tropos, etc., etc.; sin dejar de notar, digamos, los juegos con versos de 5, 6 y 7 sílabas en el primer ejemplo, y de 6,8 y 12 en el segundo. 
(la primera forma databa desde siempre; la segunda, desde la Serranilla de la Zarzuela, y la tercera desde Gutierre de Cetina) ${ }^{46}$;

b) estaba compuesto en cuartetas, independientemente de que éstas se marcaran o no tipográficamente;

c) las cuartetas estaban hechas de versos homeométricos; no quedaban ni huellas de aquella fluctuación original que tanto ha llamado la atención de los especialistas, y sobre la cual puede verse T. N. T., pp. 50, 154 y 219-220;

d) los estribillos o "complementos líricos", cuando los había, no eran parte de la estructura del romance, sino unos como paréntesis colocados a intervalos no siempre regulares;

e) el cultivo de las rimas consonantes en vez de asonantes en los versos pares, frecuente a fines del siglo xv y en la mayor parte del xvi (cf. T. N. T., pp. 154, 220 y 272), había pasado definitivamente de moda;

f) sólo el de ocho sílabas se llamaba romance; al de seis podía aplicársele el nombre no específico de endecha(s); del de siete no había sino un solo ejemplo (el de Gutierre de Cetina, cuyas obras

46 Se dirá que olvido los de cinco sílabas. Se habla, en efecto, de las coplas a la muerte de Guillén Peraza como de un "romancillo pentasilábico" (Menéndez Pelayo, citado por P. H. U., p. 108) ; BAEHR, p. 91, las llama "endecha" y remite al lugar en que habla del "romancillo"; T. N. T. las llama "endecha" y "romancillo" en la p. 142 (y "canción" en la p. 212). Estamos, creo yo, ante otro caso de confusión entre "expresión escrita" y "movimiento interno", para decirlo con las palabras de Echarri. Escríbanse las coplas en versos largos y se verá que se trata de esas series de trísticos asonantados, pero de asonancia variable - "trístrofos monorrimos" los llama impropiamente José Pérez VIDAL, Endechas populares en tristrofos monorrimos, siglos xv-xvi, La Laguna de Tenerife, 1952-, originados en (o por alguna razón asociados con) las islas Canarias, y estudiados por el mencionado Pérez Vidal y, antes de él, por P. H. U., pp. 157-158. Las coplas de Guillén Peraza (cantadas hacia 1443):

Llorad, las damas, tsí Dios os vala! Guillén Peraza quedó en la Palma, la flor marchita de la su cara.

Tus campos rompan tristes volcanes, no vean placeres, sino pesares, cubran tus flores los arenales...

son análogas a:

Si los delfines mueren de amores, triste de mí, ¿qué harán los hombres, que tienen tiernos los corazones?

Aunque me veáis en tierra ajena, allá en el cielo tengo una prenda, no la olvidaré hasta que muera.

Decididamente, no se trata de romances. $\mathrm{El}$ romance pentasílabo nació mucho más tarde, y fue, además, rarísimo. 
no estaban impresas), y se puede decir que no tenía nombre; por otra parte, no era raro que ciertos romances octosílabos o hexasílabos destinados al canto, especialmente cuando llevaban estribillo, se llamaran "letra" o "letrilla" y aun "villancico".

Si esta descripción elemental se pone en presente y en tono preceptivo ("El romance debe estar escrito en versos de ocho...", etc.), nos encontraremos con que muchos romances, quizá la mayor parte, no sólo del siglo xvn, sino del xvirI, del xix y aun del $\mathrm{xx}$, son perfectamente ortodoxos. El Catálogo que sigue recoge sólo, en principio, las desviaciones de la norma, las innovaciones, los experimentos extraños, las heterodoxias, a partir de Góngora. Así, en él irán apareciendo, sucesivamente, los romances de nueve, de once, de diez, de cinco, de doce y de cuatro sílabas ${ }^{47}$; irán apareciendo, asimismo, romances compuestos en unidades estróficas mayores de cuatro versos, y, sobre todo, gran número de variedades de estrofas, de cuatro o más versos, en que éstos son heterométricos (8-4-8-8, 7-7-711, 10-12-10-12, 8-8-8-8-4-12, 7-11-7-11-5-7-5, etc.) ; y, finalmente, irán apareciendo muchas designaciones antes inexistentes, y no siempre unívocas: romance heroico, romanee de arte mayor, endechas reales, etc. ${ }^{48}$, proliferación onomástica que corresponde, como es natural, a la proliferación de los entes.

Mi Catálogo no termina con Sor Juana, ni con el siglo xvn, sino que se prolonga hasta el último año del siglo xvirI. Los cincuenta párrafos finales no ofrecen gran cosa en materia de novedad. Para el siglo xvir mi información es aún más rala que para el xvn, pero no creo que el continuador de este estudio - si llega a haberlopueda añadir nada de importancia. La única figura interesante es allí la de Iriarte.

47 El orden cronológico no debiera descuidarse. Navarro Tomás, Arte del verso, México, 1959, pp. 153-154, puede desorientar cuando dice que el romance "primero se extendió al hexasílabo, después al endecasílabo y al heptasílabo". Podríamos pasar por alto la anacreóntica de Cetina, que, no impresa, permaneció probablemente ignorada. Aun así, los romances heptasílabos de Góngora, Lope (las famosas "barquillas"), etc., preceden con mucho al primer romance endecasílabo. Por otra parte, si no tomara en cuenta a Cetina, el romance de siete sílabas debería figurar en mi Catálogo (de hecho, Góngora lo "invento" independientemente de Cetina). El caso del romance eneasílabo (\$ 11) es dudoso. No tiene que ver con los eneasílabos ocasionales del siglo $\mathrm{xv}$ (v.gr. Carvajales, citado por T. N. T., p. 155: "et diome por marido un César / que en todo el mundo non cabía", etc.), sino con los estribillos o cabezas de villancicos populares en los inicios del Barroco. Pero es muy breve. También es discutible la designación de "romances dodecasílabos" que uso en los \$\$ 163 y 172.

48 La letra negrilla en que aparecen muchas de las designaciones indica que éstas son las empleadas por el poeta (o por los editores antiguos). 


\section{CATALOGO DE FORMAS}

[ $\$ 1$ 1] Compárense estos dos comienzos de sendas composiciones de Góngora (núms. 3 y 103):

La más bella niña de nuestro lugar, hoy viuda y sola y ayer por casar, viendo que sus ojos a la guerra van, a su madre dice que escucha su mal: Dejadme llorar orillas del mar...
Cierto doctor medio almud llamar solía, y no mal, al vidrio del orinal espejo de la salud, porque el vicio o la virtud del humor que predomina nos lo demuestra la orina con clemencia o con rigor. Buena orina y buen color $y$ tres higas al doctor...

O bien estos otros dos (núms. 1 y 104) :

Ciego que apuntas y atinas, caduco dios y rapaz, vendado que me has vendido y niño mayor de edad, por el alma de tu madre (que murió, siendo inmortal, de amores de mi señora), que no me persigas más.

Déjame en paz, Amor tirano, déjame en paz..
Baste lo flechado, Amor, más munición no se pierda; afloja al arco la cuerda y la causa a mi dolor; que en mi pecho tu rigor escriben las plumas juntas, y en las espaldas las puntas dicen que muerto me has.

Ya no más, ceguezuelo hermano, ya no más...

En los cuatro casos, la continuación de la poesía se ajusta a la forma estrófica de los comienzos que he copiado: ocho versos más estribillo. A primera vista, cuando no a primer oído, las cuatro composiciones pertenecen a un mismo género lírico. $Y$ sin embargo, no es así. Las de la primera columna son romances; las de la segunda, letrillas. En la primera columna hay asonancia; en la segunda, consonancia. Los límites entre letrilla y romance parecen en verdad muy frágiles ${ }^{49}$. Nos hallamos ante una sola extensión poética. Poéti-

49 ¿Es seguro que Góngora llamaba romances lo mismo "La más bella niña" que "Diez años vivió Belerma", lo mismo "Ciego que apuntas y atinas" que "Entre los sueltos caballos"? En su anotación al romance 94 ("Todo se murmura...") cita Millé estas palabras de Chacón: "No prosiguió [don Luis] esta letrilla" -razón por la cual faltará ese romance en la ed. de J. M. de Cossio, Romances de Góngora, Madrid, 1927. (Por otra parte, es claro que Góngora no llamaba letrillas muchas de las poesías que figuran en la sección de "Letrillas" de la ed. Millé, por ejemplo los epigramas compuestos en una décima o en dos redondillas). 
co-musical, mejor dicho. Se trata de "letras para cantar" 50. Y el romance, que se juzgaría más pobre o más monótono, con su asonancia corrida, resulta a menudo, gracias en parte a la magia de esos estribillos que Góngora sabe intercalar, más ligero, más suelto, más "artísticamente cantable" que las coplas de múltiples rimas consonantes. La maravillosa "letrilla" núm. 194:

Cuando el silencio tenía todas las cosas del suelo, y coronada de hielo reinaba la Noche fría, en medio la monarquía de silencio tan cruel caído se le ha un clavel hoy a la Aurora del seno: ¡qué glorioso que está el heno porque ha caido sobre él!...,

que es una espinela perfecta (con la particularidad de que los últimos cuatro versos lo van a ser también de las espinelas siguientes, de manera que son a la vez estribillo y parte estructural de la décima), no llega, en el sentido métrico, a los vuelos del romance núm. 75:

Yacía la noche cuando

las doce a mis ojos dio el reloj de las estrellas (que es el más cierto reloj); yacía, digo, la noche, $y$ en el silencio mayor una voz dieron los cielos (Amor divino)

50 Así intitula Montesinos la segunda sección de las Poesias liricas de Lope (t. 1, pp. 131-136), donde agrupa, con diversas designaciones, composiciones aconsonantadas lo mismo que asonantadas. Son verdaderos romances las tres serranas, los tres bailes, varias de las letras y canciones ("Dente parabienes / el mayo florido...", "f́base la niña, / noche de San Juan...", etc.), la gallarda, las tres mayas y uno de los dos villanos; incluso el villancico "Más valéis vos, Antona..." es un romance, y hasta hay, como luego se verá (\$ 4 y notas respectivas), seguidillas que son romance. "Letras para cantar", dice Montesinos (t. l, introd., p. 35), es "vocablo que Lope mismo emplearía". Y añade en nota: "Para Lope letra y letrilla no se diferencian más que en las dimensiones; ambas significan simplemente "cantables". No es infrecuente leer en obras de Lope el nombre de letrilla aplicado a las seguidillas". A la escasez de límites que estoy señalando entre coplas de romance y coplas aconsonantadas enlazadas por un estribillo, se agrega no sólo la ocasional falta de límites entre villancico y romance (recuérdese que "So ell enzina" se sentía como villancico), sino también la ocasional falta de límites entre la letra para cantar con estribillo y la sin estribillo, como es la seguidilla. "El hecho de tener estribillo -dice Montesinos- no era... criterio de clasificación para Lope". 
que era luz aunque era voz (divino Amor).

¿Quièn oyó? ¿Quién oyó?

¿Quién ha visto lo que yo? 51

Pero con este $\S 1$ no pretendo atribuir a Góngora el descubrimiento de las potencialidades líricas del romance. Sólo quiero decir que la disposición en "octetas" (u "octavillas") no se encuentra, que yo sepa, antes de 1580 , fecha de mis dos primeros ejemplos. Los tratadistas de métrica española no la mencionan ${ }^{52}$. Es bastante frecuente en Góngora. Además de los tres romances citados (núms. 1,3 y 75), la tienen los núms. $5,11,13,31,45,46,63,68,72,76$, 79 y 89 (o sea más del 15 por ciento) ${ }^{53}$.

[\$ 2] Tampoco encuentro antes de Góngora ejemplos de romance en cuartetas "de pie quebrado" (8-8-8-4), como éste (núm. 80) :

Viva el amor de Fileno, cuando no exceda, a la par del amor de su Belisa, que no hay más.

Viva la fe de Belisa, cuando no mayor, igual al amor de su Fileno, que no hay más... [Etc. ${ }^{54}$.

[§ 3] En el romance núm. 2 de Góngora, la unidad estrófica es más compleja: 8-8-8-8 + 6-6:

Los rayos le cuenta al sol con un peine de marfil la bella Jacinta, un día que por mi dicha la vi en la verde orilla de Guadalquivir... ${ }^{55}$

51 La ed. de Millé y la de J. M. de Cossío (núm. 77) ofrecen aquí una disposición tipográfica y una puntuación equivocadas, que corrijo.

52 Lo que sí mencionan es la "octeta" hecha de la suma de dos redondillas, y le dan una designación específica (no sé con qué base histórica) : copla castellana. Véase T. N. T., p. 525, y cf. infra, \$ 191. (No conozco el Repertorio de estrofas españolas de don Tomás, New York, 1968).

53 En el núm. 31, el verso "por el decir de las gentes" es a la vez estribillo y verso final (regular) de cada "octeta".

54 Es un romance dentro de otro, que comienza "Las esmeraldas en yerba". Su fecha es 1620 . Bien es verdad que para entonces ya se habian escrito otros romances heterométricos (cf. infra, \$\$ 4 y 7). En Maluenda (infra, § 9), el pie quebrado no es el cuarto, como en Góngora, sino el segundo.

55 "Sólo este primer cuartete y la vuelta [el par de hexasílabos] es suyo, pero siguióle tan bien quien lo continuó, que se pone aquí, con esta adver- 
[§ 4$]$ Lope de Vega, gran cultivador de seguidillas ${ }^{58}$ - hasta el punto de darnos la impresión de que, de no haber sido por él, la seguidilla no habría tenido, ni tendría hoy, la fama que tuvo y tiene-, ensayó desde fecha muy temprana la fusión de la seguidilla con el romance de seis sílabas que hoy se llama romancillo, y que en la época se llamaba endecha ${ }^{57}$. En El caballero de Illescas (de hacia 1602, según Montesinos) está la hermosa letra para cantar "Blancas coge Lucinda / las azucenas..." (Poesias líricas, t. 1, p. 158) . ¿Cómo designaremos esta forma? La palabra "seguidilla" se

tencia", dice Chacón. El arte del continuador se ejerció no sólo en el retrato de la hermosa rubia peinándose, sino también en la trabazón sintáctica y estrófica del estribillo hexasilábico con el "cuartete" octosilábico. - Podría añadir el romance 63, donde los versos "caridades excusadas / mia fe son" son inseparables, por el sentido, de las octetas en $o ́$ a las que sirven a la vez de estribillo, de manera que se tendría una copla de romance de diez versos, el último de ellos hexasílabos. (Léase, en cambio, sin estribillo el romance "La más bella niña" y se verá que el "Dejadme llorar" no es indispensable para el sentido: "...a su madre dice, / que escucha su mal: // «Pues me distes, madre..."”, etc.). No lo he hecho para no "inflar" el papel de Góngora en la creación de nuevos esquemas.

58 Ejemplo típico, la serie de cuatro ("A los verdes prados...", "A los prados verdes...", etc.) de Con su pan se lo coma (Poesias líricas, t. 1, p. 148). En mi no autorizada opinión, no hay verdaderas seguidillas antes de los últimos años del siglo xvI. Fue entonces cuando surgieron (por supuesto que no de la nada) con un impetu extraordinario. Muchos de los ejemplos de seguidillas anteriores a 1600 que aduce P. H. U., pp. $64-70$ y 124-136, no me parecen convincentes. Las colecciones de seguidillas anónimas de alrededor de 1600 -las "Séguedilles anciennes" publicadas por Foulché-Delbosc en $R H i, 8$ (1901), 309-331, las impresas en 1597 y publicadas por el mismo Foulché en "Les $R$ omancerillos de Pisa", $R H i, 65$ (1925), 160-263, las incluidas en el manuscrito de "Tonos castellanos" reseñado por Gallakdo, Ensayo, t. 1, cois. 1193-1203, y las demás que haya- no deben ser sino una minima muestra de lo que fue la avalancha. Se tiene la impresión de que se hacian en corrillo, con vino y guitarras. Y aún no había acabado de cantar uno su "Río de Sevilla, / tquién te pasase...l", cuando ya otro de los circunstantes buscaba un verso 2 para rimar con un verso 4 que se le acababa de ocurrir: ". . el bien que adoro". Las seguidillas se devoraban seguiditas, como las cerezas o los cacahuates. (Entre paréntesis: ¿no es claro que ésa es la "etimologia" de la palabra seguidilla? Las laboriosas explicaciones de Lang y de Hanssen, mencionadas por BAEHR, p. 251, y la no menos laboriosa nernlejidad del promio Baehr, me parecen inconducentes). Todavía treinta años después había curiosos que coleccionaban seguidillas, como lo muestra la serie de noventa y seis recogidas en el Cancionero de 1628 (ed. I. M. Blecua, Madrid, 1945, pp. 276-286). El primer tratadista que se ocupa de ellas es Correas (1626) : como se recordará, la función que él asigna al pentasílabo es la de ingrediente de las seguidillas, mientras que Carvallo (1602) le había asignado sólo la de adónico de la estrofa sáfica. (Las artes poéticas siempre van a la zaga de la práctica de los poetas).

57 Del estribillo (del Cancionero musical de Palacio, núm. 197) "De ser mal casada / no lo niego yo; / cativo se vea / quien me cativó" dice P. H. U., p. 124, que "podría tomarse por endecha, a no ser porque está clasificado como 
nos impone ante todo ${ }^{58}$. Sí, una serie de cinco seguidillas, pero de asonancia continua $e ́-a$, ni más ni menos que si fuera un romance de veinte versos, cosa que no se acostumbraba. Por eso, con el mismo derecho podemos decir que es un tipo nuevo de romance, no pentasílabo, ni hexasílabo, ni heptasílabo (la primera cuarteta es de 7-5-7-5, las otras son de 6-5-6-5), sino mixto, o anisosilábico, o heterométrico. Exactamente lo mismo ocurre en la letra de $E l$ robo de Dina (t. 1, pp. 144-145), "En las mañanicas / del mes de mayo...", idéntica a la anterior hasta en su extensión (salvo que la primera cuarteta es de 6-5-7-5) y de sonido aún más romanceril, narrativo-descriptivo ${ }^{59}$. Del mismo tipo es una serie de cuatro cuartetas que encontramos en el Cancionero de Sablonara, con música de Álvaro de los Ríos. No me consta que la letra sea de Lope, pero el estilo es cien por ciento el suyo:

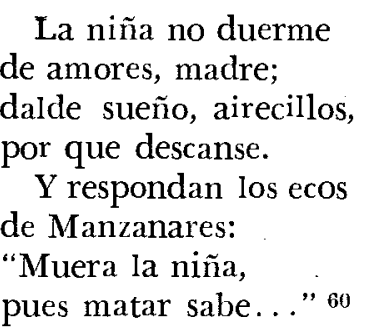

seguidilla entre las que recogió Foulché-Delbosc". Pero si Foulché-Delbosc lo encontró "clasificado" así en alguna fuente de hacia 1600 , eso no significa que lo que se sentía entonces como seguidilla se sintiera como tal en tiempo de los Reyes Católicos, cuando en verdad, según mi opinión, no había seguidillas. (Hacia 1600, la copla aconsonantada de 6-6-6-6 era una de las formas de la seguidilla). Curiosamente, la serie del Cancionero de 1628 mencionada en la nota anterior lleva un doble encabezado: "Romançe" y "Seguidillas".

58 "Deben señalarse [en el Siglo de Oro]... las composiciones en verso fluctuante de fondo de seguidilla, pero... con asonancia sostenida de romances, en las. que los versos impares son hexasílabos con mezcla de algunos heptasílabos y los pares son pentasílabos con mezcla de hexasílabos", dice T. N. T., p. 268.

59 Como contraste, vea el lector la serie de verdaderas seguidillas "A los carreteros / del buen Getafe..." (ibid., pp. -163-164), gracioso cuadro cuasicostumbrista: podría tener asonancia continua, podría ser un romance, pero Lope se decidió aquí por el brochazo libre y salteado. - En "Salteáronme los ojos / de la mozuela..." (ibid., pp. 139-140) lo que hay es un par de coplas de romance hexasílabo con estribillo inicial y final en forma de seguidilla, todo con la misma asonancia.

60. Cancionero musical y poético del siglo xvii recogido por Claudio de la Sablonara, editado (no muy brillantemente) por J. Aroca, Madrid, 1916, pp. 184-188 (música) y 308-309 (letra). Como en el caso de "Hortelano era Belardo...", se trata del final de un romance octosílabo, de la misma asonancia, "Sin color anda la niña / después que perdió su amante...", el cual, como dice Aroca, p. 396, figura anónimo en el Romancero de Durán $(B A E$, t. 16, p. 508). Hay que observar que, a diferencia de lo que ocurre con dos series 
Ya con pleno carácter de romance, por así decir, aparece esta forma en los Pastores de Belén (1612) y, menos abundantemente, en las Rimas sacras (1614). En el Romancero y cancionero sagrados de Justo de Sancha ( $B A E$, t. 35) pueden verse siete ejemplos (núms. 438,488 , y del 495 al 499). La cuarteta de 6-5-6-5 predomina abrumadoramente, pero no es la única: se dan casi todas las que solía tener la seguidilla (6-6-6-5, 6-5-7-5, 7-5-7-5, 6-6-6-6 y 6-5-6-6). Sin embargo, quien lee estas largas composiciones piadosas algo ñoñas, pero siempre con algo bello, puesto que son de Lope,

... Los cabellos de oro
parecen plata,
del puro rocío
de la mañana ${ }^{61}$,
como clavellinas
de hojas doradas,
que al alba se bordan
de pura escarcha...,

no está leyendo series de seguidillas, sino romances (o romancillos, o endechas) de nuevo cuño. Si no fuera tan fea, se podría pensar en la designación "romance aseguidillado". P. H. U., en nota de las pp. 170-171, muestra cierta indecisión: del núm. 438 dice que es "toda una canción en seguidillas" (lo mismo del núm. 488: "canción. . . toda en seguidillas") ; de los núms. 495, 496, 498. y 499 dice que son "seguidillas largas"; pero su definición del núm. 497, cuya estructura es idéntica a la de los otros, es "endechas con estribillo" - lo cual podría aceptarse, especificando sólo que se trata de endechas "irregulares" (cf. infra, Sor Juana, § 113), de 6-5-6-5 ${ }^{62}$.

[\$ 5] A semejanza de Góngora (o, evidentemente, a imitación suya), Lope también cultivó el romance dividido en unidades estróficas de ocho versos. Véanse, en el t. 1, pp. 65-106, los romances "Por las riberas famosas...", "Al pie de un roble escarchado...",

de seguidillas, núms. 7 y 8 , pp. 26-28, donde la composición musical cubre sólo la primera seguidilla (de manera que para cantar las demás se repite la música), en "La niña no duerme...", composición muy desarrollada, la música cubre los dieciséis versos de la poesía. Caso parecido es el del núm. 20, donde el cantar inserto (con la misma asonancia del romance principal) es sólo de dos cuartetas: "Si las aguas crecen / de Manzanares..." (El Cancionero de Sablonara, por cierto, no parece haber sido estudiado tanto como lo merece) .

61 Es el Cristo paciente del famoso soneto: "...que a mi puerta, cubierto de rocío..."

$62 \mathrm{P}$. H. U. mete en el mismo saco varias poesías de los Pastores que yo no tomo en cuenta por la sencilla razón de que son coplas aconsonantadas. Su indecisión onomástica es aquí igual: "canción en endecha y seguidilla" (núms. 489 y 491) y otra vez "seguidillas largas" (núms. 482, 483 y 493). 
“AApartaste, ingrata Filis...?”, “Ay amargas soledades...!”, "Lleno de lágrimas tristes..." y "De pechos sobre una torre..." En el segundo de ellos, el verso "quien tal hace, que tal pague" es a la vez estribillo y verso final de octeta; en todos los demás, las octetas van separadas unas de otras por estribillos de dos versos (de 5-11, de $9-11$ o de $11-11)^{63}$.

[\$ 6] En El mayor imposible (de 1615) hay una letra en dos estrofas, la segunda de las cuales dice (t. 1, pp. I54-I55):

No son, como dicen muchos,

las rosas alejandrinas

al tiempo que se abren, nácar, coral cuando se marchitan,

pero es verdad que se hallan en Jacinta

soles en los ojos

y perlas en la risa.

La primera estrofa ("No son de cristal las fuentes..."), de contenido análogo, pero que no logro entender del todo, tiene idéntica estructura: 8-8-8-8 + 11-6-7: una cuarteta octosilábica más el mismo añadido de tres versos, que funciona como estribillo o "complemento lírico". Pero en verdad no es un complemento, sino el segundo miembro de una frase bimembre. Se trata, en otras palabras, de dos estrofas líricas de siete versos, y a la vez, indudablemente, de un romance, puesto que a lo largo de los catorce versos hay la misma asonancia en $i$-a. Este breve cantar y el también breve de Góngora citado supra, $\$ 3$ (curiosamente, los dos en alabanza de una bella Jacinta) ${ }^{64}$, inauguran así, no una concepción estrófica del romance -pues ésta, como se habrá visto, existía desde muy antiguo-, sino nuevas formas de estrofa, que no son ya la cuarteta ${ }^{65}$ : de seis versos

63 No me voy a ocupar más de las "octetas". Baste con Góngora y Lope. Necesitaria echar una segunda mirada a las fuentes aprovechadas para mi Catálogo (muchas de ellas inaccesibles ahora para mí). Pero las posibles adiciones -v.gr. Valdivielso, $B A E$, t. 35 , núms. 451 ss.- no valen la pena. Lo que me importaba era consignar esta "estrofización" nueva del romance, puesto que lo que aportan muchos de los párrafos que siguen son estrofas y más estrofas nuevas.

64 El ya citado Cancionero de Sablonara, contemporáneo de Lope y Góngora, contiene seis composiciones (núms. 1, 13, 17, 20, 38 y 54) en las que la dama requebrada se llama Jacinta.

65 O sus múltiplos: no sólo la octeta, sino estrofas hechas de doce o de dieciséis versos (v.gr. Góngora, núms. 50 y 53). No cuento, por lo tanto, un romance como el de la Arcadia de Lope (Poesias liricas, t. 2, pp. 111-118) donde a intervalos irregulares figuran dos endecasílabos sintácticamente inseparables de la tirada a la que sirven de remate, ni un romance como el 33 de Góngora, donde, también a intervalos irregulares, los versos 3-4 de una cuar- 
en el caso de Góngora, de siete en el de Lope ${ }^{66}$. ¿Y qué pasa con la asonancia cuando el número de versos añadido a la cuarteta es impar? Pasa lo que ya había pasado en el viejo romance del rey moro que perdió a Granada: la rima se transfiere a los versos impares (;ay mi Alhama!; ...Jacinta / ...risa). Cf. infra, Sor Juana, $\$ \S$ 119-124.

[\$ 7] En la Segunda parte de las Flores de poetas ilustres de Espa$\tilde{n} a$, ordenada por Juan Antonio Calderón en Granada en 1611 y publicada por J. Quirós de los Ríos y F. Rodríguez Marín en Sevilla en 1896, se lee (pp. 252-254) un romance "A Nuestra Señora de Archidona", debido a la pluma de Pedro de Jesús, que comienza así:

¡Farol de esta comarca,

luz de Archidona,

Virgen madre de gracia,

Virgen toda graciosa!

Tu nido en alto tienes,

blanca paloma;

tan alto, que parece

escala de la gloria...,

y que así continúa, con la misma asonancia y la misma estructura de 7-5-7-7, a lo largo de sus diecinueve coplas. Se podría decir que son cuartetas de romance heptasílabo con el segundo pie algo quebrado ${ }^{67}$, y también podría decirse, quizá con más acierto, que lo

teta son "y vame tanto mejor / cuanto va de cuerdo a loco" (que tienen la apariencia de un estribillo).

66 Si alguien objeta que en los dos casos se trata de cuartetas octosilábicas comunes y corrientes separadas entre sí por interludios invariables ("en la verde orilla / de Guadalquivir", "pero es verdad que se hallan en Jacinta..."), yo le concedo razón. Pero las que tengo para incluirlos en mi Catálogo son, primero, la inseparabilidad de cuarteta y "añadido"; segundo, la uniformidad estrófica resultante; tercero, la continuidad de la asonancia a lo largo de toda la composición; y cuarto, el papel de antecedentes que estas poesías tienen en la "barroquización" del romance: cuando más adelante nos topemos con otro esquema de 8-8-8-8 + 6-6 (Sor Juana, §115), los hexasílabos serán plenamente parte de la estrofa, y variarán de una a otra. Y la próxima vez que nos topemos con un "añadido" de tres versos (Salazar y Torres, §45), también este añadido será variable.

67 No sé a qué se refiere BaEhr cuando dice (p. 91): "El pentasílabo es, sobre todo, verso usado en combinación con otros. En esta función se encuentra formando el pie quebrado del heptasílabo" (subrayo yo). Las otras dos "funciones" sí se entienden: adónico de la estrofa sáfica y elemento de la "seguidilla regularizada" $(7-5-7-5+5-7-5)$. - En cuanto al romance heptasílabo, era en 1611 todavía una rareza (los existentes no se habían impreso aún). Sin embargo, Pedro de Jesús lo practica ("A Nuestra Señora de Monteagudo de 
que hizo Pedro de Jesús fue adoptar el esquema de la seguidilla de Góngora (1609) "Las flores del romero, / niña Isabel, / hoy son flores azules, / mañana serán miel" " 88 , extendiéndola a todo un romance. De cualquier modo que sea, este romance señala un paso más en la historia que vengo trazando. No influyó, evidentemente, en la poesía posterior, por el simple hecho de que la Segunda parte de las Flores permaneció inédita durante casi tres siglos. El hecho, sin embargo, de que ocupe un lugar tan natural en mi Catálogo muestra que ese proceso evolutivo estaba en plena marcha, de tal manera que no se necesitaba su contribución.

Los editores de las Flores de Calderón aclaran (notas al núm. 166, pp. 239 y 402, y al núm. 182, pp. 404-405) que Pedro de Jesús no, es otro que el poeta antequerano Pedro de Espinosa, colector de la célebre Primera parte de las Flores, publicada en Valladolid en 1605 (fue el piadoso nombre que tomó cuando le dio por hacerse ermitaño); pero no dicen nada de la estructura de este romance. No la mencionan tampoco T. N. T. ni Baehr, evidentemente porque P. H. U., fuente tan importante para quien se ocupe de métrica española, la pasa asimismo por alto.

[§ 8] En las Obras (póstumas) de Anastasio Pantaleón de Ribera (1600-1629) publicadas por don Joseph Pellicer de Tovar, Madrid, 1634 (cito por la ed. de R. Balbín Lucas, Madrid, 1944, t. 2, pp. 99100) hay un romance "Describiendo vn terremoto", en cuartetas de 8-8-8-11:

Todo el orbe se columpia:

sin duda, señor Macario,

que, como es bola este mundo,

juega con él algún demonio al mallo...

Obsérvese, primero, que toda idea de tomar el endecasílabo como estribillo está eliminada, y segundo, que la composición de

Antequera", Segunda parte de las Flores, pp. 261-264). Era un notable experimentador, como lo demuestra su soneto en alejandrinos a la Virgen María (ibid., p. 245), caso extrañísimo y aisladísimo en toda la poesía del siglo xvn. (Los tentaleantes sonetos alejandrinos del xvi encontrados por el diligente Arturo Marasso, citado por P. H. U., p. 349, nota 2, difícilmente se lecrian en 1611).

68 Para mi, no cabe duda de que esta seguidilla (de estructura no típica) es original de Góngora. Lo mismo se inclina a pensar P. H. U., p. 165, nota 1, pero lo hace dudar el hecho de encontrarla, ligeramente variada, en el Voca. bulario y en el Arte grande de Correas, el cual, además, dice haberla oído en Salamanca. Pero es muy natural que en Salamanca hubiera aficionados a las letras cantables de Góngora, comenzando con el propio Correas. Las ligeras variantes demostrarían sólo que la hermosa seguidilla se estaba ya folklorizando. Cf. también infra, p. 379, nota 78 . 
Pantaleón se llama romance a secas. (Poetas posteriores se sentirán obligados a calificar el sustantivo: cf. $\$ \S 32,40$, etc.). La descripción del terremoto es todo lo grotesca que anuncia la primera copla. El desquiciamiento de los octosílabos por el endecasílabo quería probablemente, en la intención del poeta, subrayar esos colores grotescos.

[\$ 9] Jacinto Alonso de Maluenda es un poeta aún más dado a lo grotesco que su contemporáneo Pantaleón. Siguiendo o no el ejemplo de Góngora (supra, $\S 2$ ), publicó dos composiciones intituladas romance que son romances de pie quebrado (coplas de 8-4-8-8). El primero está dirigido "A Antandra" (Cozquilla del gusto, Valencia, 1629, pp. 77-79) y el segundo "A Anarda" (Tropezón de la risa, Valencia, s.a., p. 37). Este segundo comienza así:

Si das en pedirme a mí, bella Anarda, harás que fenezca luego el amor que te mostrava...

[ $\$ 10]$ Más novedosa es una invención que se lee en el Bureo de las Musas del Turia del mismo Maluenda (Valencia, 1631, pp. 103106). La musa de Albano declara que se atreverá a "forjar en la oficina de $[\mathrm{su}]$ entendimiento vn romance... que tenga en cada copla el postrer verso de arte mayor" (o sea la estructura 8-8-8-12), y a continuación lo forja y lo recita:

Si pides, Antandra bella, nada de mi llevarás:

poeta soy, y mi bolsa jamás ha tenido tan sólo un real...

Una vez acabada la recitación, se comenta que estos versos no dejaron de ser aplaudidos (inocente manera del poeta de darse coba a sí mismo), si bien más por su "novedad" formal que por otra $\operatorname{cosa}^{69}$, pues en efecto el tema de la dama pedigüeña estaba ya bastante trillado, por el propio Maluenda entre otros. En todo caso,

69 No hay, en cambio, mucha novedad en la "letrilla" que recita la musa de Fileno en el Bureo de las Musas, p. 115: comienza con una seguidilla de 7-5-7-5 a la que siguen, con la misma asonancia, seis cuartetas hexasilábicas, la tercera y la sexta de las cuales terminan con los versos 3-4 de la susodicha seguidilla. En esta fusión de seguidilla y endecha había llegado mucho mäs lejos Lope (como se habrá visto en el $\S 4$ ). La "letrilla" de Maluenda no va más allá de lo que había hecho Joseph de Valdivielso en su Romancero espiritual de 1612 (cf. v.gr. $B A E$, t. 35, núm. 458), o Góngora en su romance 53. Sobre la designación letrilla aplicada a romances véase supra, nota 49 , e infra, $\$ 13$. 
Maluenda estaba contento de su invención, pues incluyó otro romance del mismo tipo en su Tropezón de la risa, pp. 21-24.

Para mostrar hasta qué punto se exprimía el caletre este poeta en sus ansias de innovación, mencionaré (aunque sin darles un número en mi Catálogo) otros dos experimentos romanceriles suyos ${ }^{70}$. En una época en que el romance octosílabo ha dejado de admitir, y desde hace mucho, versos que no sean de ocho sílabas, Maluenda confecciona un extravagantísimo romance con versos de ocho, de siete, de nueve, de diez y aun de arte mayor (Bureo de las Musas, pp. 112-114: “. . . Breve fue el disparatado romance de Perardo, por que se dixesse por él: «De lo malo poco»"). Y en una época en que ha triunfado definitivamente la asonancia, hasta el punto de que se considera "falta" el meter consonantes seguidos, él publica dos romances "en consonantes": Tropezón de la risa, pp. 63-64, y Bureo de las Musas, pp. 55-57, con esta justificación: “Si poner dos [consonantes] juntos en vna copla es falta, hecho adrede y en todas es gala" 71 .

7o $\mathrm{Y}$ en esta nota, dos experimentos no romanccriles. Dice T. N. T., p. 304, hablando de la décima en el siglo xvnI: "Hasta su firme estructura métrica empezó a vacilar. Lista compuso décimas con pies quebrados..." Pero mucho antes que Lista (1775-1848) las compuso Maluenda, Tropezón de la risa, pp. 73-76. Y en 1673 las compuso también en México el presbitero Juan Vallejo Hermosillo, según se ve en la Breve relación de la plausible pompa y cordial regocijo con que se celebró la dedicación del templo de... S. Felipe de Jesís publicada ese año, y reeditada por José Pascual Buxó, Arco y certamen de la poesia mexicana colonial (siglo xvii), Xalapa, 1959, pp. 159-161: el artificio de estas décimas, escritas "singularmente con suave armonía de quebrados", mereció un tercer premio, consistente en dos candeleros de plata. Las de Maluenda, intituladas "Décimas de pie quebrado", tienen quebrados (de cuatro silabas) los versos 3, 5 y 8 . Lo mismo, exactamente, ocurre con las de Vallejo, lo que me hace pensar que el presbitero mexicano procedió con poca honradez al intitularlas "Décimas con novedad". (También Sor Juana hizo décimas de pie quebrado: véase infra, p. 384, nota 82). - Prosigue T. N. T., loe. cit.: "Décimas en verso hexasilabo se encuentran... en... Juan María Maury y en... Lista". También éstas se encuentran ya, con el nombre de "décimas endechadas", en el Tropezón de la risa, pp. 8-9, y en Cozquilla del gusto, pp. 9596, y reaparecerán en fray Juan de la Anunciación, a comienzos del siglo xvin (cf. infra, § 173). En cambio, para encontrar una décima en endecasílabos - posibilidad admitida por Caramuel, como se recordará- hay que esperar a Iriarte (ed. Clás. cast., p. 135).

71 Claro, porque se piensa que el asonante es facilón y que el consonante posee una especie de superioridad. "Pero el diablo del romance -dijo Sor Juana- / tiene en su oculto artificio / en cada copla una fuerza / y en cada verso un hechizo". Más que el empleo de consonantes en -aña y en era a lo largo de todo un romance (que es lo que hace Maluenda), ¿no es una "gala" que rimen -que rimen rerdaderamente, con satisfacción del lector o del oyentepalabras tan no rimantes a primera vista como proa, alfójar y órbita, como Venus, cielo y féretro, como Adonis y Mavorte? Paradójicamente, las "rimas dificiles" de un Góngora suelen estar en romances como "Arrojóse el mance- 
[\$ 11$]$ A fines del siglo xvi y en las primeras décadas del xvn se pusieron muy de moda en los "bailes" las coplas eneasílabas, asonantadas ("Bullicioso y claro arroyuelo / que salpicas las guijas blancas, / de tu imbidia los ruiseñores / van saltando de rama en rama") o aconsonantadas ("Adurmióseme mi lindo amor / siendo del sueño vencido, / y quedóseme adormecido / debajo de un cardo corredor") ${ }^{72}$. La más popular de esas coplas fue sin duda la de "Arrojóme las naranjicas...", predilecta de Lope ${ }^{73}$ y utilizada y parodiada también por Valdivielso y otros. El eneasílabo, dice P. H. U., p. 182, "no existe entonces como tipo métrico aceptado en la versificación regular"; y añade en la p. 184: "El que muestra predilección especial por él es Tirso de Molina, que lo prefiere a los demás tipos de versificación irregular". De tal manera es así, que es Tirso quien nos ofrece en el Siglo de Oro el único ejemplo de algo que sin mucha violencia se puede llamar romance eneasilabo:

Borbollicos hacen las aguas

cuando ven a mi bien pasar;

cantan, brincan, bullen y corren

entre conchas de coral;

y los pájaros dejan sus nidos,

y en las ramas del arrayán

vuelan, cruzan, saltan y pican

toronjil, murta y azahar ${ }^{74}$.

[\$ 12] Gracias a la diligencia de Gallardo, que en su áureo Ensayo (t. 2, cols. 194-205) dejó noticia de las Obras divinas y humanas de Jerónimo de Camargo y Zárate, nunca publicadas, podemos darnos cuenta de que este Camargo fue un poeta de más sustancia y más chispa que, por ejemplo, Pantaleón o Maluenda. Basta para

bito" o "La ciudad de Babilonia" más que en el Polifemo y las Soledades. Por lo demás, uno de los romances heptasílabos de Góngora (el núm. 40, "Moriste, ninfa bella") tiene consonantes y no asonantes. También Iriarte hará un romance aconsonantado: véase infra, p. 450, nota 162 .

72 El primer ejemplo procede del Cancionero de Sablonara, ed. cit., núm. 67, con música de Mateo Romero (el "Maestro Capitán"), y con el sorprendente título de "seguidillas"; el segundo, de un manuscrito madrileño citado por P. H. U., p. 150. En el mismo P. H. U., pp. 142-150 y 181-185, se encontrará una espléndida documentación sobre el eneasílabo en los cantares y bailes.

73 Su música, muy graciosa, puede verse en las Treinta canciones de Lope de Vega editadas por Jesús Bal [y Gay], Madrid, 1935, pp. 90-91. Véase la nota del editor, pp. 108-109, y P. H. U., p. 148, nota 2 (añádase el "Desnudito parece mi Niño...", de Pastores de Belén, que cita $\mathrm{P}$. H. U. en la p. 184, y que es una vuelta a lo divino del cantar de las naranjicas).

74 Don Gil de las calzas verdes, acto I. Es un "cantar" incluido a su vez dentro de una "canción". 
probarlo la última de las poesías copiadas por Gallardo, que empieza así:

Mari-Zápalos bajó una tarde al verde sotillo de Vaciamadrid, por que entonces, pisándole ella, no hubiese más Flandes que ver su país.

Estampando su breve chinela, que tiene ventaja mayor que chapín, por bordarle su planta de flores, el raso del campo se hizo tabí...

Es un romance en cuartetas de 10-12-10-12 que cuenta, con sales no extremadamente elaboradas, pero tampoco gruesas, una graciosa aventura erótica. Como composición poética es dignísima de figurar en antologías. Los pocos datos históricos que, sin proponérmelo, he reunido sobre el "Mari-Zápalos" me hacen ver, por lo demás, que su éxito fue fulminante. A lo largo del manuscrito (autógrafo, y con correcciones del autor, por ejemplo en la composición que justamente nos ocupa) encuentra Gallardo fechas que van de 1645 a 1653. Digamos que el "Mari-Zápalos" se escribió hacia 1650. Pues bien, los versos iniciales de $E l$ retrato de Juan Rana, de Antonio de Solís, compuesto "por los años de 1652 o poco después" (E. CoTARELo, introducción al t. 17 de la $N B A E$, p. xcv), son ya un testimonio de su fama: "Atención, que a Juan Rana le han dado / el corregimiento de Vaciamadrid..."; el anónimo Baile de Marizípalos (de "mediados del siglo xvn") "no tiene más objeto que glosar y poner en acción las entonces famosas coplas de Marizápalos" (Cotarelo, ibid., p. ccxiii); un tal Miguel López de Honrubia se apropió de las coplas de Camargo y las imprimió en Madrid en 1657 (con "variantes notables", según Gallardo, loe. cit.) ; alude a ellas Gil López de Armesto en uno de sus Sainetes, publicados en 1674 (Cotarelo, p. cxiii), y su popularidad "duró hasta el siglo xvirI, con Antonio de Zamora y Diego de Torres Villarroel" (P. H. U., p. 174) .

Camargo es poeta no sólo "de buen donaire" (Gallardo), sino de notable originalidad ${ }^{75}$. Desde el punto de vista métrico, su originalidad consiste en haber utilizado para un relato amplio y bien estructurado un molde en el que hasta entonces sólo se habían compuesto estribillos o, cuando mucho, breves canciones estróficas con cambio de asonancia (o consonancia), del tipo de "Arremanguéme

75 El tema cómico de la impotencia sexual, varias veces explotado por los poetas del Siglo de Oro en "sátiras" largas y machaconas o en epigramas concisos (como la décima de Góngora, núm. 207, "Con Marfisa en la estacada..."), es tratado sorprendentemente por Camargo en primera persona, $y$ con un acento autobiográfico que casi se siente moderno. 
y hice colada, / no hay tal andar como andar remangada" o de "Mancebito, remedia mis males, / que hay sobre de amores y falta de reales" (cf. P. H. U., pp. 141-142 y 172-181). Los versos pares de estos estribillos o cancioncitas, que abundan en la comedia a partir de Lope de Vega ("Molinito que mueles amores...", etc.), son en realidad versos de arte mayor, con sus conocidas fluctuaciones ( $T$. N. T., pp. 91-93) ; pero en el siglo xvn "fue destacándose y adquiriendo carácter propio" la variante llamada A-A, o sea el dodecasílabo de $6+6$ (ibid., p. 261). En el original romance de Camargo, que es bastante extenso -a diferencia del de Tirso, considerado en el párrafo anterior-, los versos pares son en efecto dodecasílabos, salvo el v. 10 ("muy adorada de Pedro Martín").

Ni Cotarelo ni Henríquez Ureña se dan cuenta de la originalidad de Camargo ${ }^{76}$; A. M. P., SJ, t. 1, p. 470, llama "anónimas" sus coplas, y T. N. T., p. 278, se limita a decir que "el [baile] de Marizápalos estaba compuesto en cuartetos asonantados de decasílabos dactilicos y versos de arte mayor". Es posible que Camargo se haya basado en alguna cancioncita preexistente, pero todos los datos que tengo a la mano me llevan a la conclusión de que la popularidad del "Mari-Zápalos" se debe a su largo y novedoso romance ${ }^{7 \tau}$. Esta popularidad no equivale de ninguna manera a origen popular y anónimo. Guando López de Honrubia publicó el "Mari-Zápalos" quizá ignoraba el nombre del autor. Seguramente lo ignoraban ya quienes lo cantaban por haberlo aprendido de memoria en el teatro. Se comprende que los eruditos caigan en la tentación de atribuírselo al "pueblo" 78 .

[\$ 13] Con la letrilla de Francisco de Trillo y Figueroa, Poesias zarias, heroycas, satiricas y amorosas, Granada, 1652, fol. 54 ro:

Pues que mi morena

quieren que cante,

oygan si me sopla

como me tañe...,

76 P. H. U., p. 174, nota 2, se equivoca además al decir que lo que Gallardo publica es la "variante" de López de Honrubia.

77 La música del "Mari-Zápalos" puede oírse en el disco Decca MCA-2518, en interpretación instrumental (no muy clara) del New York Pro Musica Ensemble. Procede seguramente del Teatro lirico español de Felipe Pedrell, que lamento no tener a la mano.

78 Así E. M. Torner, en RFE, 14 (1927), 417-424, empeñado en mostrar "hasta qué punto Góngora aprovechó en sus composiciones ligeras... la lírica tradicional del pueblo"; pretende engrosar su elenco con cosas como "Aprended, flores, en mi..." o como la poesía entera que comienza "Mátame los celos de aquel andaluz" (núms. 195 y 409), a pesar de que lo único que demuestran sus datos es que esas composiciones de Góngora tuvieron mucho éxito. Cf. también supra, p. 374 , nota 68 . 
nos encontramos en terreno ya conocido: es el romance en metro de seguidilla cultivado por Lope de Vega (supra, § 4). Domina el esquema 6-5-6-5, con una vaga tendencia hacia 6-5-7-5, y otra, contradictoria -y más vaga aún-, hacia la regularidad hexasilábica. Es una composición larga (dieciséis cuartetas) y sin mucho relieve.

[§ 14] En cambio, en el fol. $31 \mathrm{r}^{\circ}$ de estas Poesias varias hay un "[romance] amoroso" escrito en una forma estrófica completamente nueva, y que a partir de Trillo gozará de mucho prestigio: 7-7-7-11:

$$
\begin{aligned}
& \text {...Ya, mi Fílida dulce, } \\
& \text { buelvo a mirarte alegre } \\
& \text { y a dezir que eres mía, } \\
& \text { mía y dulce a pesar de tus desdenes... }
\end{aligned}
$$

Hay luego, fols. $40 \mathrm{v}^{\mathrm{o}}$ y $67 \mathrm{v}^{\mathrm{o}}$, otros dos romances "amorosos" con el mismo esquema (salvo que en el segundo de ellos la cuarteta inicial es, anómalamente, de 8-8-7-11). A decir verdad, la forma estrófica 7-7-7-11 era conocida (sin ir más lejos, Góngora la había empleado como estribillo en el romance núm. 59: "Oh perdido primero / tras un jabalí fiero, / no te pierdas ahora / tras esa, que te huye, cazadora"), pero funcionaba sólo como metro italiano, con rimas consonantes (Góngora) o en versos sueltos (Jerónimo Bermúdez, Cervantes). Trillo tuvo la feliz ocurrencia de hacer que el romance se asimilara esta forma, tal como acababa de asimilarse, con Camargo, la copla de "baile", y, antes, el pie quebrado y la seguidilla. Más adelante, esta estrofa se llamará endecha real ${ }^{79}$.

[§ 15] En los fols. $73 \mathrm{r}^{\circ}-75 \mathrm{v}^{\circ}$ nos ofrece el mismo Trillo y Figueroa un larguísimo [romance] heroico, también en coplas de 7-7-7-11, que comienza así:

Si alguna vez, Euterpe, mereció ser oyda

79 No me parece adecuada la manera como T. N. T., p. 266, cuenta la historia: "La composición formada por una serie de cuartetos en que los tres primeros versos son heptasílabos y el cuarto endecasílabo, recibió el nombre de endecha real. Jerónimo Bermúdez y Cervantes habían empleado esta combinación en versos sueltos, abcD. Con rimas abrazadas, abbA, aparece como parte final de un romance en el Romancero general, núm. 414. Hacia mediados del siglo [se refiere al xvn] se generalizó la forma asonantada a manera de romance... Esta forma fue cultivada principalmente por Francisco de Trillo y Figueroa y por Sor Juana Inés de la Cruz". Pero la designación endecha real, como dice el propio T. N. T., p. 527, se aplica al "romance heptasílabo en que el último verso de cada cuarteta es endecasílabo". O sea que ni lo de Bermúdez. ni lo de Cervantes, ni lo del Romancero general (ni lo de Góngora que yo añado) son endechas reales. Véase también infra, p. 420 , nota $129, y$ p. 441, nota 154 . 
mi atención dedicada

al dulce acento de tu heroyca lyra...

[§ 16$]$ Pero antes, en el fol. $42 \mathrm{v}^{\circ}$, nos había ofrecido otro romance heroyco en cuartetas normales de 8-8-8-8, dirigido "A vna dama ausente":

El mar enmudezca quanto escollo en la playa hundosa al doliente oydo ingratos los acentos me reuoca...

Lo cual nos hace ver que, para Trillo, el término romance heroico no es una designación métrica, sino que indica simplemente el tono de la composición. El de los romances "heroicos" es (pretende ser) muy elevado. En el romance "amoroso" del $\$ 14$ (y no digamos en los romances "satíricos") no hay nada de "Euterpe" ni de "heroyca lyra" ni de "playa hundosa". Abundan en las Poesias varias estos romances "heroicos" de ocho sílabas (fols. $24 \mathrm{r}^{\circ}, 53 \mathrm{v}^{\circ}$, $55 \mathrm{v}^{\circ}$, etc.). El tono del romance heroico del fol. $24 \mathrm{r}^{\circ}$ se presta a una comparación con el del "lyrico" del fol. $23 \mathrm{v}^{\circ}$. Y el estilo de la Fábula de Leandro (fol. $19 \mathrm{r}^{\circ}$ ), "heroyca", es tan elevado que se pierde en la estratósfera ${ }^{80}$.

[\$ 17] El primer caso que he encontrado de romance de once sílabas pertenece a fray Francisco Ballester en su Sacro plantel de varias $y$ divinas flores, fértil primavera del supremo jardin y celestial floresta, precioso manantial de fragantes y olorosos ramilletes para recreo espiritual de las almas, Valencia, 1652, pp. 191-196. El nombre que recibe es romance heroico. Mientras no se sepa de algún

80 Según podrá verse en mi Catálogo (y a partir justamente del párrafo siguiente), la designación más común de los romances de once sílabas fue romance heroico. En este sentido se trata de un término "técnico": heroico es sinónimo de endecasilabo o de real (cf. "octavas reales" o "endechas reales", en las cuales entra el endecasílabo, "rey" de los versos) : en el siglo xvm, doña Francisca Ossorio llamará romance real (\$ 182) lo mismo que doña Margarita Hickey y Pellizoni llamará romance heroico endecasilabo (\$209). No será necesario, entonces, que el tono de estos romances sea elevado (como el que va a verse en los $\$ \S 18$ y 152 , por ejemplo): al igual que el soneto, o que la décima, o que cualquier otro molde métrico (incluyendo, desde luego, el romance octosílabo), el romance "heroico" podrá admitir todos los tonos. Antonio de Solís juega en un romance normal de sus Poesías póstumas, p. 82 (cf. infra, $\S 57)$, con los dos sentidos del adjetivo: tras de anunciar en la primera cuarteta que se propone cantar el pie descomunal de una dama, prosigue en la segunda: "Vno de Isabel celebro, / y en un romance ha de ser; / aunque estuviera vn pie heroyco / en verso heroyco más bien". (Cf. infra, p. 384, nota 82, otro equívoco sobre pie). Pero en Trillo -como en otros poetas: infra, $\$ \S 23$, 33,54 , etc:-, romance heroico no es término de métrica. 
ejemplo anterior, nada se pierde con tener a fray Francisco Ballester por su inventor. Por desgracia, no copié ni un verso de este romance cuando tuve el libro en mis manos. Probablemente no será nada del otro mundo. Como va a verse, ninguna de las formas de romance recogidas en el presente Catálogo ${ }^{81}$ gozó de un cultivo tan asiduo; en ninguna se escribieron tantas carretadas de versos (;tragedias enteras, de cinco actos!) ; sobre ninguna han disertado tanto los eruditos. De alguna manera está bien que los orígenes del romance de once sílabas, destinado a tanta publicidad, permanezcan un tanto oscuros. Por otra parte, sobre todo a la distancia a que nos hallamos, y después de ver en los dieciséis párrafos anteriores lo que viene sucediendo con el romance desde comienzos del siglo hasta 1652 (fecha de las Poesias varias de Trillo y del Sacro plantel de Ballester), no podemos menos de pensar que era fatal la aparición del de once sílabas. Ya se le veía venir. No hacía falta ser un Caramuel para pensar: si hay romances de seis, de siete y de ocho sílabas, ¿por qué no los ha de haber de once, el verso más "numeroso", más "noble", etc.? En plan de especulación, podríamos preguntarnos si, así como detrás de los romancillos de los Pastores de Belén está la seguidilla, detrás del romance de once sílabas no estará el poema en endecasílabos sueltos. Si, en otras palabras, un pasaje como el siguiente de la Historia de Hero y Leandro de Boscán:

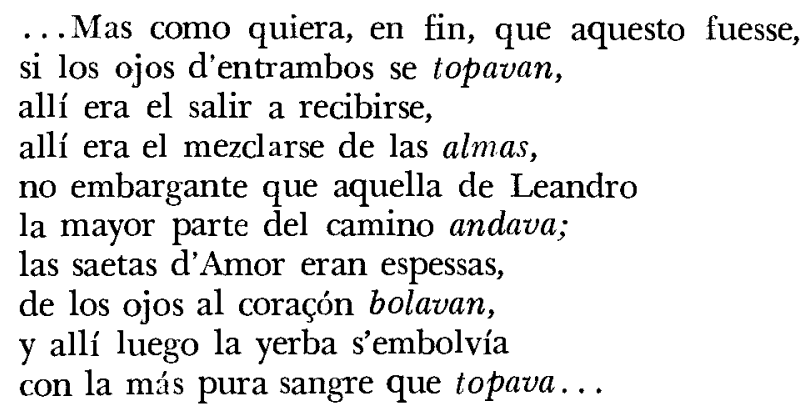

no habrá movido a fray Francisco (o a algún otro poeta) a explotar sistemáticamente un "invento" que en realidad pertenecería a Boscán. Pero no. En 1652 ya no se leía el poemón del barcelonés. (Y, a decir verdad, esos versos sueltos suyos no halla uno por dónde agarrarlos; como decía Góngora: "que yo a pie quiero ver más / un toro suelto en el campo / que en Boscán un verso suelto, / aunque sea en un andamio"). Y además, como he dicho, no hacía falta. E1 nacimiento del romance de once era ya fatal.

81 Con excepción, claro está, de los pocos casos de romances de ocho sílabas que recojo sencillamente para ilustrar la ambigüedad del término romance heroico. 
[ $\$ 18]$ Lo que se va a leer en seguida es el comienzo de un producto poético terriblemente frecuente en el siglo xvn español: el "poema" de adulación a algún alto personaje, compuesto -dan siempre ganas de pensar - con la esperanza de una recompensa en metálico por parte del señorón homenajeado. Hay de todo en este tipo de poemas (como en cualquier otro): malo, mediocre y a veces bueno. La historia, aquí, es la siguiente. El joven Juan Lisón de Tejada, hijo de una de las mejores familias de Valladolid, ofreció un día un magno espectáculo taurino a la sociedad vallisoletana, no sólo para mostrar su munificencia, sino también para lucir sus suertes, su caballo, su traje, su persona. Y, por lo visto, se lució. Ahora bien, entre el numeroso público había el porcentaje normal de poetas. Uno de ellos, que no tendría dónde caerse muerto, y que se da a sí mismo el poético nombre de "Fenicio", invitó a sus colegas a celebrar en verso las proezas del joven rejoneador, y se entendió con un impresor para publicar la guirnalda de elogios. La plaquette resultante (Pompa festival, alegre merecida aclamación, laureola que entretegieron eruditas plumas... a las floridas sienes de D. Iuan Lisón de Texada, Valladolid, 1654) termina con un poema del propio "Fenicio" dedicado "A D. Iuan Lisón de Tejada y a las plumas que le celebran" (fols. 35-38). La primera octava dice así:

Tú que en breues períodos leíste de pocos lustros el laurel dichoso, y en cláusulas sonoras has hallado sin muchas líneas Délphicos assombros; tú que en plausibles dilatadas eras hallas compuesto duplicado Pomo, que escapó de las ondas de el peligro volante braço en Thésalo Piloto...

Siguen otras dos octavas de dedicatoria (tres es, en efecto, el número ritual, a partir del Polifemo), y luego empieza el poema (como el Polifemo) con una suntuosa descripción de colores mitológicos:

Moraua el Sol en el Palacio adusto de un astro ardiente que, en ladridos sordos, vomita llamas que asseguran ethnas, vosteça rayos que compiten hornos. Era el tiempo estibal... [Etc.].

"Octavas", dije. Por supuesto que no lo son. El poema se denomina expresamente romance heroyco, y está impreso en cuartetas. Mi pequeño truco no tenía por objeto más que llamar la atención sobre el hecho de que muchos de los romances heroicos aspiran al sermo illustris de la musa épica, la musa cuyos arrebatados trans. 
portes necesitan y exigen la retumbante sonoridad de la ottava rima. Claro que ni el Polifemo ni el Panegírico al Duque de Lerma se compusieron de una sentada. $Y$, como no hubiera tenido sentido publicar diez o quince años más tarde la aclamación entretejida por las eruditas plumas a las proezas desplegadas en esa tarde calurosa de 1654, "Fenicio", con muy buen sentido, se decidió por esas octavas reales de los pobres, excelente recurso de poetas urgidos por el tiempo. Si no hubiera existido el romance de once sílabas, quizá él lo hubiera inventado. Intellectus apretatus discurrit.

[\$ 19$]$ Las Poesias varias de grandes ingenios españoles recogidas por Josef Alfay (Zaragoza, 1654) han suministrado tres números a este Catálogo. En primer lugar, unas "coplas de pie quebrado" intituladas "De un borracho a una bota" (ed. J. M. B[lecua], Zaragoza, 1946, pp. 65-66) :

A una bota le Peralta un cofrade de la cepa con lengua roma le dijo de esta manera:

"Tú me has enseñado a hablar todo género de lenguas, pero la que hablo mejor es la tudesca..."

Son, desde luego, coplas de romance. La chistosa deficiencia métrica -el "pie quebrado" de cinco sílabas, y no de cuatro como en Góngora (\$3) y en Maluenda (\$ 9) - corresponde obviamente a la deficiencia elocutiva ("lengua roma", "lengua tudesca") del borracho ${ }^{82}$. Es una composición anónima.

[§ 20] Anónimas también, y sin título, son las coplas de la antología de Alfay (pp. 165-166) que comienzan:

Si de los ojos hermosos

es propio el matar mirando,

82 En Samaniego (lib. V, fábula 10), el cojo insultado por un descortés siente "tanta cólera y tal ira, / que la muleta le tira, / quedándose, ya se ve, / sobre un pie". Recuérdese también el ingenioso pie quebrado con que Sor Juana termina la décima en que retrata a una bella (t. 1, p. 261):

$$
\begin{aligned}
& \text { talle airoso, cuerpo bello, } \\
& \text { cándidas manos en que } \\
& \text { el cetro de Amor se ve, } \\
& \text { tiene Fili; en oro engasta } \\
& \text { pie tan breve, que no gasta } \\
& \text { ni un pie. }
\end{aligned}
$$

Parodiando a Sor Juana, un seminarista mexicano (celayense) del siglo xvm, 
son los ojos de Marica

médicos, por los que han enterrado.

$\mathrm{Su}$ pelo en rizos menudos

corona su frente a rayos;

y es, por bizarro y crecido,

pródigo su cabello por largo...

Su autor, a semejanza de Camargo $(\$ 12)$, debe haber tomado ese decasílabo de comenzo esdrújulo $\$$ de estribillos como los que cita A. M. P., SJ, t. 1, p. 456: "Tárraga, por aquí van a Málaga...", "Trébole, ay Jesús cómo huele...", etc., a los que puede agregarse el de Góngora (romance 93), "Vámonos, que nos pican los tábanos..." (estribillos "quizá tradicionales", dice A. M. P.; más bien estribillos o bailes hechos por poetas de oficio desde comienzos del siglo y popularizados en medios urbanos y no propiamente rurales).

[\$ 21] Finalmente, en las pp. 190-191 hay una composición hecha en las mismas cuartetas de 7-7-7-11 que ya encontramos en Trillo y Figueroa ( $\$ \S 14$ y 15 ), y que el poeta (o el librero Alfay) llama endechas:

Amigos guardadamas,

yo os quiero mucho mal,

tocayo suyo, hizo una décima (reproducida por A. M. P., SJ, t. I, p. 509) con el juego inverso; copio también los seis últimos versos:

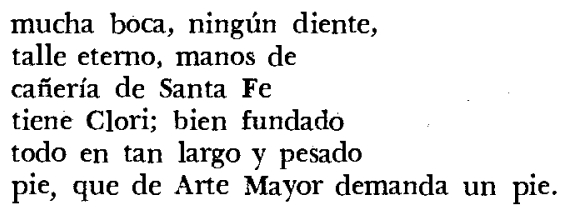

Cf. supra, p. 381, nota 80, el "pie heroyco" de la dama de Solís. En la primera de las letrillas de Góngora, "Que pida a un galán Minguilla", una mujerona que calza del 30 quiere hacerse pasar por muchachita que calza del 15 . La brevedad (o incluso ausencia) del pie es tema frecuente en Sor Juana. A la condesa de Galve le dice: "Los pies, si es que los tienes, / nunca los víde" (t. 1, p. 209) ; y: “...beso mil veces / la tierra que pisas y / los pies, que no sé si tienes" (t. 1, p. 126). Si no fuera un lugar común en la poesía de entonces, darian ganas de freudianizar un poco. - Volviendo a las décimas de pie quebrado (a las cuales ya me referí supra, p. 376, nota 70), Sor Juana tiene otras en una de sus piezas teatrales (t. 3, pp. 339-340); y tiene también unas "décimas con estrambote" (ibid., pp. 453-455), o sea con un añadido enlazado por la rima consonante. (A. M. P., "Índice antológico" del t. 3, las llama "décimas con cauda", pero también llama así las de las pp. 387-390 y 490-493, que son otra cosa: entre décima y décima hay respectivamente tres y cuatro versos de seguidilla, o sea asonantados, sin ninguna relación métrica con la décima).

83 Alfay imprime aparte la palabra esdrújula, de manera que las coplas dan la apariencia de ser de cinco pies, el penúltimo quebrado. 
y veinte coplas quiero

holgarme con vosotros, y no más...

(Y, en efecto, las coplas son veinte justas).

[\$ 22] "Pocos lectores modernos han repasado las obras poéticas del Conde don Bernardino de Rebolledo, señor de Irián. Aunque ofrecen evidente curiosidad, es necesario un poco de valor para entrar en [ellas]" 84 -el mismo que hace falta para entrar en tantas otras. Una de las curiosidades de las de Rebolledo es que incluyen una epístola escrita en romance de once sílabas, "Carta escrita de Copenhauen el año de 1654 a don Francisco de Rebolledo y Palafoz", que empieza: "Señor marqués, ya debo a Madrid canas...", y que termina con esta cuarteta:

...Basta qu'el empeñar caudal tan corto en tan profunda inmensidad recelo; perdonad lo prolixo del discurso y no estrañéis la nouedad del metro.

La cautela era pertinente. Don Francisco, deudo seguramente de don Bernardino, podría extrañarse: ¡cómo! ¡una epístola no escrita en tercetos! ¿qué novedad era ésa? Wilson y Blecua (loc. cit.) interpretan de otra manera el último verso: como si don Bernardino se atribuyera la invención del nuevo "metro"; Rebolledo, dicen, "introdujo, o ayudó a introducir, el pesado romance heroico, vehículo obligado de tantas tragedias del neoclasisismo" 8a. Pero no sólo no lo introdujo -existían los precedentes de Ballester y de "Fenicio" (\$§ 17 y 18) y no me extrañaría que otros que se me habrán escapado-, sino que tampoco creo que haya contribuido a difundirlo ${ }^{86}$,

84 Palabras de E. M. Wilson y J. M. Blecua en su "Introducción" a las Lágrimas de Hieremias castellanas de Quevedo, Madrid, 1953, pp. Ixxv-lxxvi. De estas páginas procede el material del presente párrafo. Cuando manejé los Ocios u Obras poéticas de Rebolledo, Amberes, 1660 (cf. mi artículo "Dido y su defensa", Fil, 8, 1962 [Homenaje a María Rosa Lida], pp. 315-316 y 321322), estaba muy lejos de imaginar que el presente material iba a interesarme.

$8 \overline{\text { " }}$ "Rebolledo fue admirado por los neoclásicos porque él mismo tenía sus puntos y ribetes dieciochescos, quizá por el hecho de haber vivido tanto tiempo en el extranjero" (ibid., p. lxxvii). Fue, en más de un sentido, un excéntrico. Su tragicomedia Amar despreciando riesgos es pre-neoclásica. En cuanto a la "pesadez" del romance heroico, véase supra, p. 356 y nota 37 . No me cabe duda de que la "Carta escrita de Copenhauen" es pesada, porque Rebolledo lo era: pocos poetas del siglo xvn son tan razonadores, tan antipoéticos y prosaicos como él.

86 Compárese el prudente "introdujo o ayudó a introducir" de WilsonBlecua con lo que dice Baehr sobre Sor Juana, infra, p. 412, y sobre Valenzuela, infra, p. 435 (§ 143). 
pues no hay señales de que las obras de Rebolledo hayan sido muy leídas por sus contemporáneos ni por los poetas de la generación siguiente.

[§ 23] El Espejo poético en que se miran las heroycas hazañas y gloriosas victorias executadas y conseguidas por don Francisco Fernández de la Cueva, duque de Alburquerque..., Granada, 1662, nos ofrece (fol. $21 \mathrm{v}^{\circ}$ ) un romance heroyco: "heroico" por el asunto, no por la forma, que es la de cuartetas octosilábicas. (Me remito a lo dicho a propósito de un romance análogo de Trillo, § 16).

[§ 24] Quizá el colector de las poesías de diversos ingenios que integran este Espejo poético (leídas en una "academia" o velada literaria) dudó cómo designar la de los fols. $29 \mathrm{v}^{\circ}-32 \mathrm{v}^{\circ}$, romance en coplas de 11-11-11-11; y para evitar anfibología con el romance "heroico" anterior, decidió llamarlo romance endecasílauo. O quizá la designación ya existía, pero no la he encontrado con anterioridad a 1662 .

[§ 25] Domingo Garcia Peres, en su Catálogo biográfico y bibliográfico de los autores portugueses que escribieron en castellano, Madrid, 1890, pp. 366-368, publica un romance de don Francisco Manuel de Melo ( $†$ 1666) "A Carlos $V$ al hacer sus exequias en su retiro de Yuste", romance, dice, "que poseemos manuscrito, y no viene en el tomo de sus Obras métricas". Es endecasílabo:

Monarca invicto cuya excelsa frente respeta el orbe en el postrer aliento, aun más augusta en nobles desengaños que entre caducos lauros y trofeos...

(No es la musa épica quien canta, sino la musa trágica y lamentosa).

[\$ 26] Lo que sí viene en las Obras métricas de Melo (León de Francia, 1665) es esta bonita "letra para cantar", dedicada a festejar las bodas de algún amigo (reproduzco los versos citados por $\mathbf{P}$. H. U., p. 180) :

¿Qué me pides, zagal, que te cuente del verde consorcio que ayer tarde vi, si no han vuelto hasta ahora mis ojos, que todos llevaron los novios tras sí?

Una tarde -que el bien viene tardede un mes que se llama el mes del abril, cata aquí que se rompen los cielos y mandan al sol de tarde salir... 
Es el metro -y la asonancia también- del "Mari-Zápalos" de Camargo (\$ 12): cuartetas de romance de 10-12-10-12. La ambientación es también la misma: paisaje campirano, personajes "populares" pero vestidos de seda.

[\$ 27] En Los cinco libros "De la consolación" que compuso Seuerino Boecio, varón consular y patricio romano, traducidos en lengua castellana por don Esteuan Manuel de Villegas..., Madrid, 1665, se despliega un buen abanico de formas estróficas, en respuesta a la diversidad de formas métricas empleadas por Boecio. La que aquí interesa es una curiosa cuarteta de 5-5-7-7 - "cierta manera de seguidillas", dice MenÉndez Pelayo, Bibliografía hispano-latina clásica, Madrid, 1902, p. 264 (ed. de Santander, 1950, t. 1, p. 325). En ella traduce Villegas el metro 7 del libro I y el 7 del III. Cito el segundo:

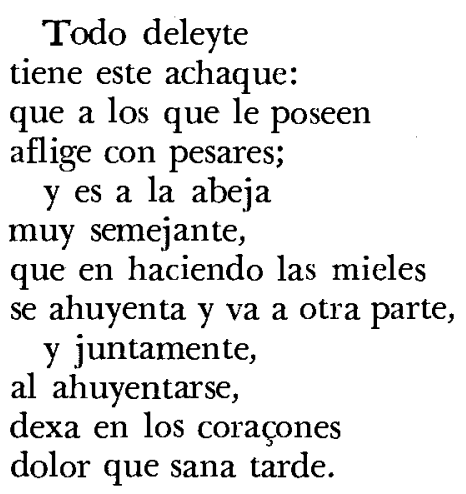

[§ 28] Once años después de publicar sus Obras varias hizo imprimir Francisco de Trillo y Figueroa una Descripción del sitio, templo, y milagrosa imagen de N. S. de la Cabeza de la ciudad de Motril (Granada, 1663). La forma métrica no tiene designación, pero se trata de un romance de once sílabas, con asonancia $i$-a en los 16 versos de la dedicatoria, y $\dot{a}-a$ en los 448 del poema, bastante gongorino:

Donde soberbio el Mar Mediterráneo de Sexifirmio en la espaciosa playa corona, en cambio de corales tiernos, su altiva frente de melifluas cañas...

[§ 29] "Calderón -dice P. H. U., p. 179- muy raras veces recoge cantares del pueblo, prefiere tomarlos de poetas cultos o, más exactamente, de Góngora; pero sí gusta de la versificación popular: tiene afición desmedida al metro de gaita gallega, y en él compone can- 
tares que con frecuencia se prolongan, por repetición de uno o dos versos, interrumpiendo el diálogo de las comedias, a través de una o varias escenas, a veces de todo un acto". Sin haber emprendido sobre la mole de versos calderonianos la exhaustiva indagación que realizó Henríquez Ureña, pero basado, por una parte, en el rebusco que él me ha obligado a hacer para mi artículo, y, por otra, en la visión que este artículo me va dejando, me atrevo a matizar lo de la "versificación popular". Tampoco aquí, creo yo, abre Calderón sus oídos a las voces del "pueblo", a los cantares del vulgo, sino que también aquí acude a los poetas cultos que a lo largo de decenios han ido formando ese corpus de versificación irregular que P. H. U. estudia. Los "cantares" compuestos por Calderón, de cuatro o cinco versos (por ejemplo, el "Ruiseñor que volando vas, / cantando finezas, cantando favores..." citado ibid.), se parecen a los de Lope y Tirso. Si en algo se distinguen los de Calderón es en que son más polimétricos y en que emplean más la consonancia que la asonancia.

Sólo uno de los ejemplos aducidos por P. H. U. es auténtico romance: el del auto La serpiente de metal, cuya "acción" transcurre en el desierto, durante el viaje del pueblo escogido a la Tierra Prometida:

Despertad, despertad, israelitas, del pálido sueño que ocioso dormís; no perezosos os tenga el descanso al ver que os espera una tierra feliz...

Es no sólo el mismo metro, sino incluso la misma asonancia del "Mari-Zápalos" (\$ 12) y de la "letra para cantar" de Melo (\$ 26), pero el tono no podía ser más distinto. El romance tiene 44 versos, pero éstos no se dicen (o cantan) de corrido, sino que hay intercalaciones de diálogo dramático, además de las del estribillo.

En las mismas cuartetas asonantadas de 10-12-10-12 está compuesta una canción de otro auto sacramental, Las espigas de Ruth. Son 56 versos, también con intercalaciones de diálogo. Su tono es más lírico ${ }^{8 \tau}$ que el del otro:

87 Plenamente lírico es el cantar de la tercera jornada de El castillo de Lindabridis, en cuatro cuartetas de 10-6-10-12, "A la sombra de un monte eminente...", descripción del nacimiento y muerte de un arroyuelo (con un final casi "modernista": "...y parece su espuma una línea / que labra dibujos de plata y marfil"). Pero cada una de esas cuartetas tiene su asonancia (en $a$, en $\dot{e}$, en $\dot{o}$ y en $i)$, y por lo tanto no se trata de un romance. Su relación con los dos que cito en este párrafo es la misma que la de "A los carreteros / del buen Getafe..." con "Blancas coge Lucinda / las azucenas..." (supra, $\$$ y nota 59). Y, de hecho, esos cantares, "Porque soplan quedito los aires...", "Jilguerillo que al alba saludas...", etc., ¿no son como seguidillas de versos largos? 
¡Fértil tierra, que el blando rocio 88

en copas de flores le bebes al cielo cuando en ti le esparce y enjuga la aurora llorando y el alba riendo!

En confianza de Dios, este grano a tus piadosas entrañas ofrezco: jay de ti si, tierra viciosa, le mezclas con hierba que no es de provecho!... ${ }^{89}$

[§ 30] En otro auto sacramental, El maestrazgo del Toisón, Calderón pone en boca del Bautista una tirada de romance en "octetas" de 8-8-8-8 + 6-6-6-6:

¡Bella Sinagoga, de estos montes reina soberana! El gran Príncipe del Austro, que con la divina Infanta del Líbano, a quien su hermosura exalta tanto, que hallar pudo en sus ojos gracia,

felices bodas celebra, y te pide que a ellas vayas con tus familias, vestidas de ricas nupciales galas, porque, aunque en su mesa a todos aguarda, no se ha de sentar el que no las traiga...

(Según la acotación teatral, las partes octosilábicas son "representadas", y las hexasilábicas "cantadas").

88 En la ed. de los Autos por A. Valbuena Prat se lee "que en blanco rocío", lo cual parece errata. Corrijo de acuerdo con A. M. P., SJ, t. 1, p. 470.

89 Se me ocurre una observación (no sé si ociosa) a propósito de la aparente irregularidad o fluctuación de estos versos de Calderón. Los pares son siempre de doce silabas (en el segundo ejemplo, hay que leer rïendo y pïa. dosas con diéresis), con cesura o sin cesura (pues si se hiciera cesura en el v. 4 del primer ejemplo, "al ver que os espera \| una tierra feliz", el verso resultaría de $6+7$ ). Los versos impares, en cambio, no siempre parecen de diez sílabas, sino de once (v. 3 del primer ejemplo) y de nueve (vs. 3 y 7 del segundo). Lo que sugiero es que Calderón hace en ellos una especie de cesura: "no perezósos-os || tenga el descanso", $5+5$ (primer hemistiquio "esdrújulo) "; "cuando en ti- || le esparce y enjuga", "ay de ti- || si, tierra viciosa", $4+6$ (primer hemistiquio agudo). P. H. U., p. 179, observa que a menudo prescinde Calderón de la cesura central del verso de arte mayor, convirtiéndolo en un bloque uniforme ("Antorcha será que os alumbre sutil...", etc.). Yo diría: tanto en los dodecasílabos como en los decasílabos calderonianos a veces hay cesura y a veces no. 
[\$ 31] Un romance en cuartetas de once sílabas, llamado simplemente romance, puede leerse en la Pyra real que erigió la maior Athenas a la mejor Magestad, la Vniuersidad de Salamanca a las immortales ceniças, a la gloriosa memoria de su rey y señor $D$. Phelipe IV el Grande. Refiérela, por acuerdo de la misma Vniuersidad..., el M. Francisco de Roys, del orden de S. Bernardo, cathedrático de vísperas de Theulogía ..., Salamanca, 1666, pp. 449-456 ${ }^{90}$.

[\$ 32] La Academia que se celebró en Sevilla jueves diez y siete de febrero de 1667 años en festejo de las Carnestolendas, Sevilla, 1667, nos ofrece en el fol. $17 \mathrm{v}^{\circ}$ un romance en cuartetas de 8-8-8-11, esquema inventado, al parecer, por Pantaleón de Ribera (supra, $\S 8$ ). Lo único notable es que aquí esa forma recibe la curiosa designación de romance disparado.

[\$ 33] Un romance heroyco ("heroico" sólo por el asunto y el lenguaje, pues es octosilábico) figura en las Delicias de Apolo, recreaciones del Parnaso por las tres musas Vrania, Euterpe y Caliope, hechas de varias poesias de los mejores ingenios de España, recogidas y dadas a la estampa por don Francisco de la Torre y Sevil, Madrid, 1670, p. 158.

[\$ 34] En la Cima del monte Parnaso español, con las tres musas castellanas Caliope, Vrania y Euterpe, fecundas en sus assumptos por las varias poesias de don Joseph Delitala y Castelvi, Cáller, 1672, pp. 301-302, hay un romance en cuartetas de 7-7-7-11.

[§ 35] Y otro en cuartetas de 8-8-8-11 allí mismo, pp. 428-434.

[\$ 36] El de cuartetas de 11-11-11-11 recibe por primera vez (que yo sepa) el nombre de romance de arte mayor en la Academia con que el Exmo. señor marqués de Xamaica celebró los felizes años de .. Maria Ana de Austria el día 22 de diziembre de 1672, Cádiz, 1673, fols. 36-38.

[\$ 37] Entra ahora en el Catálogo un primer poeta mexicano: el bachiller Diego de Ribera, "autor de más de una docena de impresos, la mayor parte en rimas", y elogiado por Sor Juana Inés de la Cruz (A. M. P., PN, t. 2, pp. lxi-lxii). En sus Villancicos en honor de San Pedro (México, 1673) ${ }^{91}$ hay una jácara a la cual pertenecen estos versos:

90 Una lista de los poetas y jueces que intervinieron en este homenaje poético-fúnebre puede verse en Gallardo, Ensayo, t. 4, cois. 267-268.

91 Que Méndez Plancarte no conocía seguramente en 1944, pues no los menciona en el lugar que acabo de citar. 
óiganos explicar los alientos del político Pedro, y sus prendas: máximo por las llaves que guarda, bélico por los hechos que intenta...

Párpados en el Huerto cerrados tímidas publicaron sus fuerzas...

Pródigo satisfaga en suspiros, líquido se deshaga en ternezas... ${ }^{92}$

Fuera del verso 2, que se siente como una pequeña falla (pues ni el esdrújulo es trisílabo ni el acento recae en el mismo lugar que en el resto de la "jácara"), los demás siguen a ojos vistas una ley muy precisa: son decasílabos que comienzan con una palabra esdrújula de tres sílabas. Es el romance decasilabo más antiguo que he encontrado ${ }^{93}$.

[§ 38] El poeta que sigue al bachiller Ribera es casi mexicano: se llama Agustín de Salazar y Torres. De los treinta y tres años que vivió (1642-1675), quince (1645-1660) los pasó en la Nueva España. En México se imprimió su "Descripción en verso de la entrada del Duque de Alburquerque" (¡cuando él tenía once años!), y en México se graduó en leyes. "Estancia decisiva - dice A. M. P., PN, t. 2, p. lviii-, y más en un poeta de tamaña precocidad, ya totalmente formado cuando en 1660 volvió a la Península con el Duque de Alburquerque ${ }^{94}$, para contraer ilustre matrimonio, estrechar amistad con Calderón, acompañar a la Emperatriz a Alemania, llegar a capitán del propio Duque, en su nuevo virreinato de Sicilia, y mo. rir en Madrid... dejando un caudal poético que su íntimo Vera Tassis editaría parcialmente: la Citara de Apolo".

De ese caudal poético interesan aquí las invenciones y los juegos y experimentos que Salazar y Torres hizo con el romance -que no son pocos (\$\$ 38-46: número sólo inferior al de Sor Juana). Aunque mi objetivo es tan limitado, los lectores que conozcan menos que yo a Salazar me concederán que es uno de esos poetas a quienes valdría la pena conocer más. Calderón, a quien se enco-

92 Reproducidos por A. M. P., SJ, t. 1, p. 457. "Una Jácara o Romance", dice el erudito investigador, pero "romance" parece glosa suya para explicar lo que es "jácara".

93 Ribera pudo haberse inspirado en los estribillos sueltos del tipo de "Trébole, ay Jesús cómo huele", o en las coplas anónimas de la antología de Alfay, donde ese decasílabo es verso 4 de cuarteta (supra, $\$ 20$ ), o bien en el ejemplo de León Marchante (infra, p. 396, nota 97) . A. M. P. dice que Ribera "mezcla irregularmente ese decasílabo con otros metros", pero los versos que transcribe tienen todos diez sílabas.

94 No me extrañaría que Salazar fuera uno de los poetas que en 1662 ce. lebraron en Granada las "heroycas hazañas" del Duque (cf. supra, § 29). 
mendó la censura de la Citara, la llama "pulido tesoro de la lengua castellana" y, con frase que suena auténtica, declara haber encontrado en ella "mucho más de lo que esperaba..., en lo grave de sus heroycos metros, lo dulce de los lyricos y lo apazible de los jocosos". (Casi se percibe, en el severo Calderón, una especie de envidia por la fantasía métrica de su amigo). Pero los críticos modernos, de Menéndez Pelayo a Guillermo Díaz Plaja, lo han desdeñado. Méndez Planearte, que era muy mexicanista, después de recoger varias muestras de este "desdén o paladina ignorancia", concluye (loe. cit., p. lix) : "Por eso, al tornarlo a México ${ }^{95}$, lo hacemos tanto más gustosos y seguros, cuanto que el general despego de los críticos y antólogos peninsulares parecería... renunciar a su parte de esa gloria".

Mis ejemplos proceden, salvo indicación en contrario, de la $C y$ thara de Apolo, Varias poesias divinas y humanas de D. Agustin de Salazar y Torres, publicadas por Juan de Vera Tassis y Villarroel, Madrid, 1681 (2 tomos) ${ }^{96}$. Y sea el primero un romance de once sílabas (t. 1, p. 38), llamado romance endecasylavo.

[§ 39$]$ Pero romance endecasylavo se llama asimismo, de manera inesperada, un tipo que ya conocemos: el compuesto en cuartetas de 10-12-10-12. Dice así una de sus coplas (t. 1, pp. 158-159):

... No es Primavera, porque antes las flores procuran, en vano, imitar de su tez. aquel ámbar que aspira el jazmín con los aromas que exala el clavel...

En el mismo metro, y con la misma asonancia en $i$ que ya Melo y Calderón habían tomado del "Mari-Zápalos", está compuesta la "Loa a los años de la Reyna" (t. 2, p. 232) :

Olorosas, gustosas, vistosas, con vozes de olor a la flor os rendid..., y constantes, amantes, brillantes, con vozes de luz a la luz aplaudid...

(Como podrá verse por los dos ejemplos, la manera como Salazar y Torres maneja este metro se parece más a la de Calderón, $§ 29$, que a la de Camargo, $\S 12$ ).

95 Incluye, en efecto, varias muestras de la producción poética de Salazar, excelentemente anotadas, en el t. 2 de sus Poetas novohispanos, pp. 125-138.

96 Para los ejemplos que proceden del t. 2 me he ayudado de las citas que hace A. M. P., loc. cit., y anotaciones a algunas poesías de Sor Juana. (Méndez Plancarte confiesa no haber podido leer más que ese tomo segundo). Es casi seguro que algunas formas estróficas de romance se me habrán escapado, pues cuando tuve en las manos la Citara lo que me interesaba era sobre todo la cronología y la onomástica del romance de once sílabas. 
[\$ 40] También se llaman romance endecasylavo otros dos (t. 1, pp. 118 y 151) compuestos en cuartetas de 8-8-8-11.

[§ 41] Al comienzo del t. 2 (p. 2) hay unas endechas reales de 7-77-11, y de terminación esdrújula, al nacimiento de Carlos II, retoño

de Felipe el magnánimo,

cuyos blasones ínclitos

apenas hallan término

del vago sol en el eterno círculol

[§ 42] Hasta aquí, todas las formas de romance usadas por Salazar nos son ya conocidas. Mientras no se encuentren casos anteriores, podemos considerarlo como el inventor de las cinco siguientes:

Cuartetas de 7-11-7-11 (t. 2, p. 138), con los heptasílabos esdrújulos y los endecasílabos agudos:

Escuchad, montes ásperos, ya generosa emulación de abril, pues vuestras rocas rígidas envidia dan al celestial zafir...

[\$ 43] "Quintetas" de 7-7-7-7 + 10 (t. 2, p. 197):

Mejor Cupido, Enone

en las espumas canas

enamora las ondas,

pues - venciendo sus armas-

flecha con ojos, vuela sin alas...

[\$ 44$]$ "Sextetas" de 7-7-7-7 + 10-12 (t. 2, p. 189):

Al nacer el aurora

en cuna de zafir,

hasta que entrega al aire

plumas de oro y carmín,

no se atreve el cristal a correr,

el ave a cantar ni la selva a reír...

[§ 45] "Septetas" de 6-12-6-12 + 6-6-6 ("A la purissima concepción de Nuestra Señora", cit. por P. H. U., p. 208), donde los versos 1 y 3 son siempre esdrújulos:

Si es aurora nítida

y precursora luziente del sol, que ignoró crepúsculos 
y aun el primer matutino esplendor, su puro candor luego el cielo copia y la tierra no.

Si es cedro que al Líbano ornó de hermosura en perpetuo verdor...

[§ 46] Finalmente, un laberintho (t. 2, pp. 3-4, "Loa a los tres años del Rey [Carlos II]"), o sea un romance endecasílabo de cuyos versos pueden cercenarse tres sílabas, para convertirlo en octosílabo, y otras dos más, para hacerlo hexasílabo:

$$
\begin{aligned}
& \text { Aurora, - bello - nuncio de las luces, } \\
& \text { dorado - Cenit, - centro de los rayos, } \\
& \text { purpúrea, - veloz - Tarde voladora } \\
& \text { y negra - Noche, - sombra del ocaso..., }
\end{aligned}
$$

lo cual constituye un juego de ingenio demasiado arduo: ¿quién que escuche sólo la versión más breve ("Nuncio de las luces, / centro de los rayos, / Tarde voladora, / sombra del ocaso") podría darse cuenta de que son sendos apóstrofes a la Mañana, al Mediodía, a la Tarde y a la Noche?

[\$ 47] La Cythara de Apolo se publicó en 1681, seis años después de la muerte de Salazar. En alabanza del poeta, su amigo Gaspar Agustín de Lara compuso un romance endecasílavo (cuartetas de 11-11-11-11) que aparece en los preliminares del primer tomo.

[ $\$ 48] \mathrm{Y}$ ahora, cátate aquí de nuevo a Mari-Zápalos, instalada ya definitivamente en el engaste métrico que le conocemos. En un villancico del maestro Manuel de León Marchante (1631-1680), racionero de San Justo y Pastor de Alcalá, reaparece, en efecto, no sólo ese metro de 10-12-10-12 que Salazar y Torres o su editor Vera Tassis no han vacilado en llamar por su nombre natural de roman. $c e^{97}$, sino también la rústica y pulida muchacha, oliendo a flores $\mathrm{y}$

97 Las Obras poéticas pósthumas del maestro Manuel de León Marchante, divididas en tres clases, sagradas, humanas y cómicas, fueron editadas por un "aficionado" suyo muchos años después de su muerte: Madrid, 1722 (t. 1) y 1733 (t. 2). Yo las tuve en mis manos (en una ficha anoté: "Hay muy bonitas cosas"), pero no tomé apuntes. Lo siento, porque estoy seguro de que mi Catálogo, aunque confesadamente incompleto, podría enriquecerse mucho con una búsqueda metódica. Los $\$ \$ 48$ y 49 proceden de los datos que encuentro en A. M. P. (el cual menciona en $S J$, t. 2, p. lxxii, un tomo 3 "que no conocemos"; pero dice PaLAU: "El editor... promete en los preliminares... un tomo tercero", propósito que "no tuvo efecto"; supongo que debía contener las "obras cómicas", o sea las comedias, de las cuales registra Palau varias 
explicándole al Niño Dios, con un “estilo vulgar" que está hecho de ingeniosas ingenuidades, por qué, habiendo podido venir a Belén con el traje leonado o turquí del disanto, ha decidido venir con el verde de todos los días:

Con su estilo vulgar, la zagala, compuesto de frases de aquí para allí, por decir cosas dulces al Niño llegó a verle, llena la boca de anís...

"Mari-Zápalos soy, Niño mío, aquella zagala de Vaciamadrid...

Que yo venga vestida de verde ha habido quien muerda; mas viéndote a ti, si ésta es noche que triunfa la Carne, no es fuera del caso traer perejil..." 98

[§ 49] La segunda muestra de León Marchante es más novedosa que la primera. Su forma recuerda la de las "quintetas" de Salazar y Torres ( $\$ 43)$, pero es más complicada, con esa ley de los esdrújulos que se verá mejor si cito las dos coplas que trae A. M. P. en el lugar citado:

Nítidos alumbran astros, cándidas respiran flores cuando nace el bello Infante, con quien se eclipsan y encogen nítidos astros, cándidas flores.

Rústicas humildes pieles púrpuras igualan nobles cuando pastores y reyes besan sus plantas, conformes rústicas pieles, púrpuras nobles...

[§ 50] En la Academia que se celebró en dia de Pascua de Reyes..., Madrid, 1674, fols. $31 \mathrm{v}^{\circ}-32 \mathrm{v}^{0}$, hay un romance en cuartetas de 8-88-11 que se llama romance endecasílavo.

[§ 51] En cambio, en la Academia que se celebró en la Real Aduana desta Corte, siendo presidente D. Melchor Fernández de León,

ediciones sueltas). - Además del esquema 10-12-10-12, León Marchante dejó una muestra por lo menos del esquema 10-10-10-10, con esdrújulo trisílabo al principio de cada verso: "Ángeles, qque se forma el aurora!..." (A. M. P., $P N$, t. 3, p. 135). No lo incluyo porque se trata de una cuarteta aislada. (Cf. también A. M. P., $S J$, t. 1, p. 457: “'Ténganse, que Dios nace en el hielo!...”: sólo tres versos).

98 Alfonso Méndez Plancarte, espíritu afinado, buen catador, escribió sobre el hoy olvidado poeta un entusiasta artículo, "León Marchante, jilguerillo del Niño Dios", Abs, 11 (1947), 493-530. 
Madrid, 1678, un romance hecho en las mismas coplas de 8-8-8-11 recibe el extraño nombre de romance echasylavo (pp. 67-70) .

[§ 52] En esa misma Academia figuran dos romances en coplas de cuatro endecasílabos. El primero (pp. 76-79) se llama romance heroyco.

[\$ 53] El segundo (pp. 86-88) se llama romance endecasylavo.

[\$ 54] El Certamen poético, docta emulación y lid ingeniosa que se celebró en honor del principe y cabeça de la Iglesia S. Pedro, publicado en Granada en 1678, nos ofrece dos composiciones llamadas romance heroyco (fols. $8 \mathrm{v}^{\circ}$ y $65 \mathrm{v}^{\mathrm{o}}$ ) : las dos son romances octosílabos, pero altisonantes.

[§ 55] Lo mismo digo del romance heroyco que figura en la $A c a$ demia que se celebró en esta Corte en amante júbilo y vasalla de. mostración de los desposorios de Sus Magestades don Carlos Segundo con doña María Luisa de Borbón, Madrid, [1679], sin paginación.

[\$56] Sí consta, en cambio, de cuartetas de 11-11-11-11 el Romance heroico que describe succintamente las grandes, continuadas, sumptuosas y reales fiestas con que festejó el felicissimo y alegre himeneo de las Cathólicas Magestades... don Carlos de Austria y doña María Luisa de Borbón el excelentissimo señor Marqués de los Vélez..., Nápoles, 1680. (La pobre María Luisa, casada contra su voluntad a los diecisiete años, moriría poco después, probablemente de tedio: cf. $\S 91)$.

[\$ 57] De las Varias poesias sagradas y profanas que dexó escritas (aunque no juntas ni retocadas) don Antonio de Solis y Ribadeneyra [† 1686], Madrid, 1692, probablemente no hubo ninguna más famosa que las endechas "A la conversión de San Francisco de Borja" (p. 132), de lectura imprescindible, desde luego, para quienes se interesen en el tema tan barroco-español del "desengaño":

Parece que se escuchan

de aquel cadáver yerto

avisos que revelan,

divina Providencia, tus secretos...

En el mismo metro de 7-7-7-11 están escritas las endechas intituladas "Sentimientos de vn amante" (ibid., p. 134). Y en la edición 
moderna de las Varias poesias, Madrid, 1968, pp. 390-392, se añaden otras endechas análogas, tomadas de un manuscrito.

[\$ 58] El Dignissimo panegirico que canta Apolo al muy excelente señor don Juan Francisco de la Cerda Enriquez Afán de Ribera Aragón Folch de Cardona y Córdova, Duque de Medina-Celi, de Segorbe... [etc.], Autor... Joan de la Victoria Ovando Santarén y Loaísa..., Málaga, [1681], lleva en los preliminares un romance endechasílavo: cuartetas de 7-7-7-11.

Aquí una observación tal vez no del todo impertinente. El autor del Dignissimo panegirico fue un enamorado de la profesión militar y un fervoroso patriota. Creía con todas las veras ( en esos tiempos!) que las victorias militares españolas eran las que determinaban el tejemaneje de toda la política y toda la diplomacia europeas. A raíz de una de ellas decidió llamarse "Juan de la Victoria". Con sus apellidos y con los del homenajeado se cubren aquí todos los requisitos de pomposidad vigentes para las portadas de esta clase de publicaciones. (Véase infra, $§ 90$, donde la sonoridad de la primera parte del título es más contundente, mientras que la segunda ostenta todavía un apellido más de Ovando). Si del presente Catálogo de esquemas métricos quitáramos a los militares, a los eclesiásticos y a los necesitados de adular al poderoso - a título individual o en "academias"-, los materiales que nos quedarían serían muy exiguos.

[§ 59] Otro aplaudidor de hazañas militares es Luis Enríquez de Fonseca, que en sus Ocios de los estudios: Versos y discursos philológicos..., Nápoles, 1683, p. 31, dedica un romance heroico (cuartetas de 11-11-11-11) "A la armada de Francia".

[§ 60] En Enríquez de Fonseca, por lo visto, el adjetivo "heroico" vale más para el fondo que para la forma, pues también llama romance heroico uno de ocho sílabas (p. 5l), perfectamente distinguible, por su tono engolado, del "romance lírico" de la p. 85.

[§ 61] No sólo eso, sino que en los Versos anexos de Marcial Benetasúa Gutmán, compañero de "estudios" -o, mejor, de "ocios"del belicoso Enríquez de Fonseca, hay (p. 3) un romance lyrico ¡de once sílabas!

[\$ 62] Un romanze heroico (de once sílabas) de Gaspar Mercader y Cervellón, conde de Buñol (1656-1686), puede verse en el ms. CLXXIX de la Hispanic Society of America (New York), fol. 218.

[\$ 63] El ms. XXXII de la Hispanic Society, fol. 87, tiene dos endechas endecasylabas (esquema 7-7-7-11). 
[\$ 64] En ese mismo manuscrito hay tres composiciones llamadas romance mudo endecasylabo. No se trata de ninguna innovación métrica: son romances comunes y corrientes de once sílabas, pero presentados en forma de dibujitos (lo que hoy llamamos "jeroglífico": en vez de escribir "Alatorre", por ejemplo, se dibuja una ala y una torre). Para que no nos quepa duda en cuanto a la interpretación, el copista "traduce" los dibujitos: "Muerte, María, a la serpiente has dado..." (fol. 125), "Vela Virgen, Gabriel, vela Real Ave..." (fol. 137, donde sin embargo nos cabe duda: "Ve la Virgen..."?), y "Penachos abalança hasta María..." (fol. 143) 99. Hay también redondillas mudas, décimas mudas, etc.

[§ 65] Academia que se celebró en Badajoz en casa de D. Manuel de Meneses y Moscoso..., Madrid, 1684, fol. 8: romance en cuartetas de 11-11-11-11 (sin designación).

[§ 66] Ibid., fols. $22 \mathrm{v}^{\mathrm{o}}-24 \mathrm{r}^{\mathrm{o}}$ : endechas endecasylabas (7-7-7-11).

[§ 67] Académico obsequio celebrado en casas del señor D. Alonso Verdugo de Albornoz a las bodas del señor D. Pedro Verdugo de Albornoz y Vrsúa con la señora D. Ysabel Maria de Castilla Lasso de Castilla, siendo presidente D. Francisco Félix de Olea y Piña, [Granada?, 1685?], fols. $27 \mathrm{r}^{\circ}-29 \mathrm{v}^{\circ}$ : romance heroyco (= cuartetas de once sílabas).

[\$ 68] Todos los académicos obsequios hasta aquí mencionados son niñerías en comparación del que se tributó a comienzos de 1685 al rey Carlos II (ese Carlos II retratado con más verdad aún que la de Carreño y la de la historia en un cuento de Francisco Ayala, "El Hechizado"), a causa de un gesto inaudito, despampanante. El 28 de enero de ese año paseaba el rey con algunos de sus cortesanos, en coche, por las orillas de Madrid, cuando vio a un humilde cura que, acompañado del sacristán, llevaba el Sagrado Viático a un enfermo. Con enorme pasmo de los cortesanos, y de unas mujeres que lavaban ropa en el no caudaloso Manzanares, el rey cedió su coche al cura (y al azorado sacristán), se puso al estribo, "de gentilhombre", e hizo que sus paniaguados acompañaran a pie al Santísimo hasta la casa del moribundo. La convocatoria a los poetas fue inme-

99 Véase Antonio Rodríguez-Moñino y María Brey Mariño, Catálogo de los manuscritos poéticos castellanos (siglos $x v$, xvi y xvii) de The Hispanic Society of America, New York, 1965, t. 1, pp. 237-238. En mi ficha encuentro la siguiente anotación: "Sospecho que todo esto procede de la Lyra poética de Vicente Sánchez". No tengo manera de verificarlo. Esta Lyra poética (Zaragoza, 1688), por cierto, debe tener cosas aprovechables para la historia que estoy haciendo. Alfonso Méndez Planearte no da señales de haberla conocido. 
diata, y no menos inmediata la respuesta. Los resultados se publicaron poco después de un impreso de respetable volumen: Academia a que dio assumpto la religiosa y cathólica acción que el Rey N. S. ...executó el día 28 de henero de este año de 1685. Celebróse el dia 3 de febrero en casa de don Pedro de Arce... Fue presidente don Andrés Sánchez de Villamayor... Sácala a luz Sebastian de Armendáriz..., Madrid, 1685. ¡Menos de una semana después de ejecutada la religiosa y católica acción, se tenía la respuesta masiva y tumultuosa!

La "academia" está dividida en quince "assumptos" 100. En el cuarto de ellos ("Es más blasón para Carlos haber sucedido a Ro-

100 Algunos ejemplos: "Bexamen que dan las mulas del coche de Su Magestad a la mula del dotor, que estava a la puerta del enfermo" (assumpto VI) ; "Manzanares pretende la corona de todos los Ríos del Orbe por auer sido su ribera teatro de tan heroica acción", en "romance yocoserio" (assumpto IX); romance "en estilo asturiano", o sea en bable: un rústico les escribe a sus gentes contándoles el formidable suceso (assumpto $\mathrm{X}$ : zconocerán este texto, fols. $24 \mathrm{r}^{\circ}-26 \mathrm{r}^{\circ}$, los dialectólogos asturianistas?) ; seguidillas satíricas sobre el susto del sacristán al entrar en el coche de Su Majetad (assumpto XIII) : romance puesto en "boca" del coche (assumpto XIV); quintillas "A las bendiciones que echaron las labanderas a Su Magestad y fiesta que hizieron" (assumpto XV). - En México, en el mismo año de 1685, los herederos de la viuda de Calderón imprimieron una Copia de carta escrita de Madrid, que no era sino la convocatoria a los númenes novohispanos para que se unieran al coro madrileño. El impreso mismo incluye ya varios "Sonetos de ingenios de esta corte", como uno de Diego de Ribera (cf. supra, \$ 37) y otro de Sebastián de Gadea, "joyel del más puro Góngora" como lo califica A. M. P., PN, t. 3, n. xxxi (puede verse ibid., pp. 73-74), aunque no el de Sor Juana Inés de la Cruz, "Altísimo señor, monarca hispano..." (A. M. P., SJ, núm. 194, t. 1. p. 303). Solís y Ribadeneyra escribió dos sonetos a ese asunto (Varias poesias, ed. de 1692, pp. 12 y 13; reedición de 1968, pp. 72 y 73; cf. también el ms. XX de la Hispanic Society of America, fol. 12). - Un último dato que saco rápídamente de mis apuntes (pienso ocuparme algún día más despacio de todo esto) : En Madrid se había dado a glosar la siguiente quintilla, espantosa en verdad, pero que invitaba a grandes tours de force: "La acción religiosa de / Rodulfo y de Carlos, dio / cetro al Austria, y a la fe / cedió el trono, pero no / glosarán cómo o por qué". El famoso pedante Joseph Pellicer de Ossau y Tovar se la mandó a su hijo Ignacio Álvarez Pellicer de Toledo, que a la sazón estudiaba en Bruselas, y don Ignacio se puso in continenti a glosarla, y a publicar su glosa en los Ocios impresos en el año mismo de 1685, seguramente en Bruselas (pp. 73-75). También Sor Juana glosó la endiablada quintilla. Entre sus obras inéditas mencionaba Castorena "Una glossa en dézimas a la inclyta religiosa acción de nuestro Católico Monarca (que Dios guarde) en aver cedioo el Trono [sic!] a la Divina Magestad Sacramentada". A. M. P. (SJ, t. 1, pp. xliv-xlv) la daba por perdida, pero ha sido encontrada y publicada por W. C. BRyant, "Reaparición de una poesía de Sor Juana Inés de la Cruz, perdida desde 1714" (en realidad desde 1700), Anuario de Letras, México, 4 (1964), 277-285. - Otra respuesta poética a la "heroica acción" podrá verse infra, \& 73 . 
dulpho de Auspurg en el zelo cathólico que en la Corona Real") se piden expresamente endechas endecasílabas.

[§ 69] En el fol. $19 \mathrm{v}^{\circ}$ de la Academia hay un romance de arte mayor (cuartetas de once sílabas).

[\$ 70] En el fol. 5 hay otro de once, sin designación alguna.

[\$ 71] Y en el fol. 13 un romance en cuartetas de 8-8-8-11, llamado romance endecasílabo.

[§ 72] En los Ocios de don Ignacio Alvarez Pellizer de Toledo, [Bruselas?], 1685, p. 79, hay un romance heroyco (cuartetas de once).

[§ 73] Como queda dicho supra, nota 100, don Ignacio Pellicer se encontraba en Bruselas en el momento de la religiosa acción de Carlos II. Otro poeta, don Joseph Pérez de Montoro, se hallaba en Cádiz, donde parece haber publicado, en 1688 (¡tres años después!) su Romance hendecasílabo al augustissimo Sacramento del Altar, en ocasión que el rey... Carlos II exercitó su innata fe acompañando al viático a casa de un pobre. Está hecho en versos de once sílabas.

[§ 74] Cuando, muchos años después, se publicaron las poesías de Pérez de Montoro (Obras pósthumas lyricas, humanas y sagradas, Madrid, 1736) 101, esa misma composición se llama "Romance he. royco al Santíssimo Sacramento... en ocasión que... Carlos Segundo exercitó su innata fe y heredada devoción a tal Mysterio" (t. 1, pp. 31-34).

[§ 75] En estas Obras pósthumas hay mucha vacilación en cuanto a la designación del romance de once sílabas. Al registrado en el párrafo anterior sigue (p. 35) uno llamado romance de arte mayor (y en el resto del volumen hay varias composiciones así, llamadas indiferentemente romance heroyco y romance de arte mayor).

[\$ 76] A continuación del primer romance de arte mayor hay otros dos en el mismo metro, llamados romance a secas.

[\$ 77] Y en el tomo 2, p. 21, aparece la designación romance endecasílavo.

101 Pérez de Montoro (1627-1694) es uno de los poetas del siglo xvir más olvidados o maltratados por los críticos modernos, y uno de los reivindicados por A. M. P., SJ, t. 2, pp. xx-xxiv. Sobre la relación de Montoro con Sor Juana véase infra, p. 425, rota 134 . 
[\$ 78] Pérez de Montoro fue, como Salazar y Torres y como Sor Juana, un gran innovador y explorador en los terrenos de la métrica, y concretamente del romance ${ }^{102}$. No hay, por ejemplo, antes de él ningún caso de cuartetas de romance 8-8-11-11 (apud A. M. P., $S J$, t. 2, p. xxiv) :

Ven, Señor, a que los ojos que cegó delito infiel, acierten el camino del llorar con la luz que en los tuyos han de ver...

[§ 79] Sus cuartetas de 7-11-7-11 (ibid., p. xxiii) :

Démosle, por que lloren con menos inquietud sus ojos tiernos, una fe siempre viva de que en su llanto está nuestro consuelo...

no son tan artificiosas como las de Salazar y Torres $(\$ 42)$, pero en otras ocasiones, a la vez que inventa nuevos metros, demuestra que él también sabe de juegos con esdrújulos y agudos.

[§ 80] Así en estas cuartetas de 10-10-10-9 (citadas ibid., pp. xxixxii) :

Pródigo de sus gracias el Altísimo, dándole cuanto quiso el amor, hízola, como exenta del féretro, tálamo de su dilección...

[§ 81] Y así, sobre todo, en este romance de 10-10-10-5 (Obras pósthumas, t. 2, p. 142), con diez esdrújulos en cada cuarteta:

¡Témplense las angélicas cítaras! ¡óiganse, que en sus métricas cláusulas término la dulcísima música pone a las lágrimas!...

[\$ 82] No podia faltar en mi Catálogo un certamen literario de jesuitas. Los frutos poéticos del que se celebró en el Colegio de la Compañía de Valencia en honor de San Francisco Javier se reunieron en un tomo de tamaño considerable, intitulado Sacro Monte

102 En los dias en que hojeaba los libros que cito, como ya he dicho varias veces, no pensaba en un artículo como éste. Una consulta más cerrada de las Obras pósthumas de Pérez de Montoro sin duda ampliaría mi Catálogo. Para las citas que siguen dependo sobre todo de A. M. P. 
Parnaso de las Musas católicas de los reynos de España, que vnidas pretenden coronar su frente, guarnecer sus fallas con elegantes poemas en varias lenguas, en elogio de San Francisco Xavier..., publicado por Francisco Ramón Gonçález (Valencia, 1687). No hay un solo tipo de romance con el que no nos hayamos topado en los párrafos anteriores. Lo único digno de nota es la gran indecisión que muestran las designaciones. El romance en cuartetas de endecasílabos se llama de cuatro maneras distintas. En las pp. 62-63 se llama simplemente romance.

[\$ 83$]$ En las pp. 34-35 se llama romance de arte mayor.

[§ 84] En las pp. 35-38 y 53-55 se llama romance heroyco.

[\$ 85] Y en las pp. 230-232 y 238-240 se llama romance endecasylabo.

[ $\$ 86]$ Por otra parte, en la p. 213 la designación romance endecasylabo se aplica al hecho en cuartetas de 8-8-8-11.

[§ 87] Y en la p. 88 nos encontramos con un "romance endecasílabo acróstico, empezando con esdrúxulos", que es en realidad decasilabo, análogo al que ya hemos visto $(\$ 37)$ del bachiller Diego de Ribera:

Sátiro el demonio a Francisco, áspero, con rigor atormenta; número de parciales convoca, fáciles al herir su inocencia...

[ $\$ 88]$ Por último, la composición de las pp. 240-241, que puede leerse, ad libitum, como romance heroyco, como romance castellano y como endechas, es análogo al "laberintho" de Salazar y Torres (§ 46). El esfuerzo de ingenio que este juego implica no sólo no disimula el desesperante acartonamiento de los versos, sino que lo pone de relieve:

Ardiendo - vivo - de Xavier el fuego, sagrado - Ethna - que en mil lenguas habla, anciosas - vozes - hasta el cielo sube, amante - llora, - y a Iesús exclama . . ${ }^{103}$

103 Intercalo aquí una breve reflexión sobre la palabra endecha. Según la inscripción que lleva este laberinto, el romance hexasílabo "De Xavier el fuego, / que en mil lenguas habla, / hasta el cielo sube / y a Iesús exclama..." se llama endechas. También Caramuel (apud EciIARri, p. 193), cuando descompone el verso de arte mayor, dice que está hecho de dos mitades "reducibles 
[\$ 89] La letra de los Villancicos que se cantaron en los maytines de la Natividad de Nuestra Señora en la... Cathedral de México..., compuestos en metro músico por Antonio de Salazar (México, 1688), pertenece al bachiller y presbítero Gabriel de Santillana. El tercero de los villancicos es un romance decasílabo de comienzo esdrújulo, como el que acabamos de ver en el $\$ 87$. La cita procede de A. M. P., PN, t. 3, pp. 133-134:

Cánticos a la más bella Infanta, célebres, con acordes acentos, término de la gracia divina, ámbares los exhala su cielo.

Órganos de los aires, sonoros pájaros, que acuchillan los vientos, éxtasis le tributan, acordes números, continuados gorjeos...

[ $\$ 90]$ Juan de Ovando, con quien ya nos hemos encontrado, era, como buen militar, hombre sistemático. En 1688 publica en Málaga otra plaquette en celebración de hazañas guerreras: Orfeo militar, cuya belicosa música celebra los felices triunfos que en la sagrada guerra de Viena y Buda an alcançado contra el Sultán de Asia las imperiales armas del césar Leopoldo Primero... por Joan de la Victoria Ovando Santarén Loaisa y Roxas. Al igual que la otra ( $\$$ 58 ), ésta lleva, en los preliminares, un romance endechasílabo hecho en cuartetas de 7-7-7-11.

[\$ 91] En el manuscrito LX de la Hispanic Society, fols. 136-137, hay un "Romance a la muerte de la Reyna endecasílauo. Murió a

a endechas". Ahora bien, este término técnico coexistía con la acepción primaria de 'queja, lamentación', etc. Cuando Góngora, en la letrilla núm. 167, dice que si los cuatreros gitanos entran en el portal de Belén habrá que cantarle endechas al buey "y a la mula otro que tal", está empleando la palabra en el sentido cotidiano (iAdiós buey, adiós mula!). Pero sus endechas (en sentido técnico) "Hermana Marica..." o "Hanme dicho, hermanas..." no son quejumbrosas ni nada por el estilo. La palabra endecha(s) designaba sobre todo el romance hexasilábico (como en la Picara Justina, ed. cit., t. 1, p. 152), o bien el verso de seis sílabas (por ejemplo en Francisco de la Torre), y también, más genéricamente, las composiciones escritas en versos de menos de ocho sílabas. Por eso no me parece adecuado que T. N. T., en un libro técnico, defina la endecha (p. 527) como 'composición de duelo'. El primer romance hexasílabo que se conoce, la Serranilla de la Zarzuela, no es composición de duelo, como tampoco el que ha motivado ahora esta reflexión. Claro que en muchas composiciones confluyen los dos sentidos de la palabra. La núm. 40 de Góngora (heptasilábica) es una de ellas. (BAErrr traduce endecha por Todesklage, y en la traducción española se retraduce absurdamente 'queja de muerte', p. 100, nota 52). 
[espacio en blanco] de febrero año 1689". Comienza: "Esta que sobre altar de desengaños..." (La reina muerta es María Luisa de Borbón, o de Orleáns, cuyas bodas, diez años antes, vimos celebradas, $\$ \S 55$ y 56 , en dos romances heroicos, uno octosílabo y otro endecasílabo).

[§ 92] El maestro Antonio de Salazar volvió a hacer en 1689, como en 1688 ( $\$ 89)$, la música de los Villancicos que se cantaron en los maitines de la Natividad de la Virgen en la catedral de México, pero el autor de las letras no fue esta vez un clérigo, como lo era el bachiller Santillana, sino un seglar: el capitán Alonso Ramírez de Vargas, natural de la ciudad de México, poeta fecundo y nada despreciable (véase A. M. P., PN, t. 3, pp. xxxiv-xxxvii). El cuarto de esos Villancicos (reproducido ibid., p. 95) es un romance pentasílabo, forma de insigne rareza en los Siglos de Oro:

Una en esdrújulos
letrilla clásica
a la Purísima,
que voy cantándola..
La que teniéndose
por sierva y párvula,
juzgarse mínima
tuvo por máxima,
de las estériles
ya plantas áridas,
con pompas fértiles
nace, flor cándida.

[§ 93] En ese mismo año de 1689 se publicaron en la Puebla de los Ángeles unos Villancicos dedicados a la Asunción de la Virgen, escritos por el licenciado Antonio Delgado y Buenrostro, natural de Sevilla y aclimatado desde su infancia en Puebla. De ahí cita A. M. P., PN, t. 3, p. 32, estas "originales endechas" en estrofas de seis versos $(7-7-7-7+10-7)$ :

¿Quién es, decidme, aquella

de quien, como del alba

el sol, el de Justicia

nació de sus entrañas?

Tened, reparad: que ésa es la aurora

que ágil se levanta...

[\$ 94] De este mismo Delgado y Buenrostro menciona A. M. P. (loc. cit., p. xiv) "un polimétrico romance endecasílabo" escrito en 1699 , "ya en decadencia prosaica", imposible de comparar, dice, con el 
"límpido soneto" del Triunfo parténico publicado en la p. 32. Por desgracia -desde el punto de vista no de la Poesía, sino de las modestas finalidades de mi Catálogo-, A: M. P. no reproduce ni un fragmento, de manera que nos quedamos en la duda de lo que significa precisamente el adjetivo "polimétrico". (Cf. infra, p. 417, nota 126$)$.

[\$ 95] De manera arbitraria, he asignado el año 1690 a Sor Juana Inés de la Cruz, cuya producción poética está fechada entre 1676 y 1691. "En la segunda mitad del siglo xvn, mientras declinaba en España la rica polimetría desplegada en la versificación de la lírica y del teatro del Siglo de Oro, Sor Juana Inés de la Cruz empleaba en sus obras una variedad de metros y estrofas apenas igualada por ningún otro poeta anterior. Contra lo corriente en el período clásico, las poesías de la citada autora ofrecen en este sentido un repertorio más extenso que el que se registra en sus obras dramáticas, $y$, dentro del conjunto de sus poesías, fue especialmente en las de carácter devoto, más que en las profanas, donde Sor Juana esforzó su interés por la combinación de ritmos y metros. Su ejemplo influyó sin duda en las experiencias métricas que se observan en otros autores mexicanos de fines del siglo xvn y principios del siguiente". Son palabras de Tomás Navarro en su artículo "Los versos de Sor Juana", $R P h, 7$ (1953-54), p. 44. Aunque el párrafo es justo, y aunque se aplica perfectamente a la "barroquización" del romance, que es lo que ahora me interesa, yo haría alguna ligera ampliación. Lo que dice don Tomás de la poesía lírica y la poesía dramática (mayor riqueza métrica en la primera) y de la poesía profana y la poesía religiosa (mayor actividad en la segunda) vale para Sor Juana, pero también para sus contemporáneos. (No sería arriesgado decir: vale para Sor Juana porque vale para su época). El ejemplo de Sor Juana influyó sin duda en los poetas mexicanos posteriores, pero también en los poetas españoles. Y además, en Sor Juana habían influido las experiencias métricas que se observan en algunos poetas mexicanos -y no digamos españoles- que la precedieron. Sor Juana fue durante decenios el poeta español más famoso, el más editado (en España, por cierto: no en México), pero había muchos otros, contemporáneos, o ligeramente anteriores o posteriores a ella, y hoy olvidados, que también hacían innovaciones y también eran imitados. Sor Juana vivió en una época de extraña efervescencia. Ella fue la más admirada, pero hubo muchos como clla ${ }^{104}$. En va-

104 Lo que parece haber movido a Alfonso Méndez Plancarte a compilar su valiosísima antología de Poetas novohispanos fue, como él dice en el t. 3, p. xviii, restituir a Sor Juana "a su cuadro lírico". Véase allí su rechazo de la ligereza de Jiménez Rueda (Sor Juana, excepción que "salva del nau. 
rios casos es difícil decidir si una composición es de Sor Juana o de Manuel de León Marchante; pero en los no pocos de composiciones ("villancicos" sobre todo) que se publicaron sin nombre de autor en México o en Puebla, la decisión es imposible. Le fue imposible, en todo caso, a Alfonso Méndez Planearte, y ningún sorjuanista ha sabido lo que él sabía. En la Nueva España de tiempos de Sor Juana había mucha gente (aunque no tanta como en España, claro) superpreparada para continuar, complicar o inventar todos estos primores métricos que al hombre de hoy podrán parecerle inútiles, o intrascendentes, o "excesivamente barrocos", pero que primores siguen siendo. Por eso, en los treinta y tres párrafos que a partir de éste dedico a Sor Juana no hago distinción entre poesías publicadas con el nombre de la monja y poesías "atribuibles" ${ }^{105}$.

$\mathrm{Y}$ he aquí, para comenzar, una forma princeps de romance. En todo caso, yo no he encontrado ningún romance pentasílabo anterior a 1680 , que es la fecha de este cantar navideño (núm. xxxiii) :

¡Mírenlo, mírenlo,
qué hermoso nace!
ITóquenle, tóquenle!
'Cántenle, cántenle!
Mírenlo niño,
con ser gigante;
háganle fiestas,
cántenle, cántenle...
Mírenlo en pajas
al tierno amante;

fragio la total producción del siglo xvn"), de Menéndez Pelayo ("en tal atmósfera de pedantería y de aberración, tiene su aparición algo de sobrenatural") y de Sánchez Mármol ("en medio de tanta inanidad, [surge Sor Juana] de súbito, como torre en solitario campo"). Hay que añadir que los poetas mexicanos posteriores a Sor Juana siguieron recibiendo cuanta producción poética se imprimía en España (el comercio librero era mucho mejor entonces que ahora). Bien visto, es un poco grotesco lo que dice BAEmr, p. 224, acerca del romance heroico o endecasílabo: "En el Modernismo alcanza gran florecimiento y divulgación, sobre todo en Hispanoamérica, donde lo había usado por primera vez hacia 1680 Sor Juana Inés de la Cruz". Y en cuanto a las palabras de Navarro en su citado artículo sobre "Los versos de Sor Juana", p. 50: "E1 romance endecasílabo, después de sus ejemplos, fue conquistando en número creciente partidarios y cultivadores", hay que hacer una atenuación: Sor Juana fue, simplemente, uno de tantos practicantes de ese metro ya bien establecido. 105 Para aligerar un poco esto de guarismos, voy a citar simplemente el número que tienen las poesías en los dos primeros tomos de la ed. de Méndez Plancarte. El tomo 1 contiene los núms. 1-216; el tomo 2, los núms. 217-366 y i-lxxxii (estos números romanos indican poesías atribuibles). Las referencias al teatro sí llevarán indicación de tomo y página. Prescindo también de las fechas (salvo cuando hagan al caso). 
ríndanle afectos, cántenle, cántenle...

Muy adecuadamente, este romancillo se llama juguete ${ }^{106}$. Podemos dar por seguro que en él se inspiró el capitán Ramírez de Vargas para el que compuso nueve años más tarde (supra, § 92) ${ }^{107}$, con la diferencia de que él extrema la forma (la barroquiza), haciendo que todos los pentasílabos sean esdrújulos, cosa no tan fácil en español como en latín:

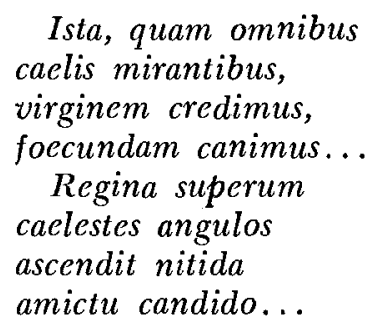

He copiado, como ejemplo de la mayor facilidad del juego en latín, precisamente los comienzos de dos romances pentasílabos de Sor Juana (núms. 255 y liv) escritos en latín eclesiástico, en latín de Breviarium, pero según las leyes prosódicas y métricas del español ${ }^{108}$.

¿Querrá decir esto que el romancillo de cinco sílabas se inventó en México? No lo creo. Mi Catálogo, ya lo he dicho varias veces, es muy elemental, es apenas un comienzo. Tiene que haber romanci-

106 Término ya existente, o sea "técnico". Juan de Salinas había escrito romancillos (hexasilábicos) llamados juguetes (BAE, t. 42, pp. 253-254).

107 El capitán era admirador de la monja: véase el soneto que le dedica en la Fama y obras pósthumas, ed. de Madrid, 1714, p. 281.

108 Entre el núm. 255 (de 1679) y el núm. liv (de 1686) se podrian situar otros dos romancillos pentasílabos esdrújulos en latín (citados por A. M. P., $S J$, t. 2, pp. xxxix-xl y 392-393) : el de José de la Barrera Varaona, 1682 ("Jam Sol clarissimus / Justitiae nascitur, / nive candidior, / igne flammantior...") y el de fray Nicolás Ponce de León, 1684 ("O Virgo virginum, / gressus accelera! / Quo nunc progrederis? / Veni, pulcherrima!..."). Pero he preferido no incluirlos en el Catálogo. - T. N. T., p. 268, nota, menciona uno solo de estos romancillos de Sor Juana (el núm. 255) y alude a "otras composiciones pentasílabas en latín de escritores mexicanos contemporáneos" de ella, o sea las citadas por A. M. P. Menciona también allí el romancillo pentasílabo en español de Ramírez de Vargas, pero no el "¡Mírenlo, mírenlo...!" de Sor Juana, lo cual parece simple descuido, sobre todo porque cita en cambio el breve estribillo del núm. xxxyi, "Ésta es María, / que se levanta / como la aurora..." (Como ya he dicho supra, p. 363, en este artículo no tomo en cuenta los estribillos). Por lo demás, T. N. T. no menciona estos casos por ser romances, ni les aplica esa designación, sino por estar escritos en pentasilabos (que es el verso tratado en su p. 268). 
llos pentasílabos hechos en España. Si los tratadistas de métrica no los mencionan es que nadie los ha redescubierto. T. N. T. cita para el siglo xv (p. 142) las coplas de Guillén Peraza, llamándolas expresamente "romancillo" -según yo no lo son ${ }^{109}$-, y para el siglo xvi (p. 213) una tirada de 72 pentasílabos en la Nise laureada de Bermúdez, pero se trata de versos sueltos, clasicizantes, sin asonancia ni consonancia ${ }^{110}$, y no vuelve a aparecer la palabra "romancillo", para el de cinco sílabas, hasta la p. 319 , donde se refiere a la segunda mitad del siglo xviIr ${ }^{111}$.

[\$ 96] Aunque, como dije en la introducción, no entran en mi Catálogo los metros de romance existentes en tiempo de Góngora, o sean los de ocho, de seis y de siete sílabas (en ese orden cronológico) ${ }^{112}$, llamaré la atención en este párrafo sobre un largo pasaje de $E l$ divino Narciso (t. 3, pp. 33-43) -y otro más breve de $E l$ cetro de José (t. 3, pp. 204-205) - en que, a intervalos irregulares, y sin relación visible con el sentido, se intercalan, en medio de una tirada de romance de ocho sílabas, cuartetas hexasilábicas de la misma asonancia:

109 Véase supra, p. 364, nota 46. Pero tampoco es cosa de polemizar con quienes prefieran llamarlas así. (En todo caso, las coplas de Guillén Peraza no fueron redescubiertas sino en los tiempos modernos).

110 BaEHr, que menciona, como vimos (supra, p. 352), los 16,000 pentasílabos en que Matheu y Sanz tradujo (1665) el Spill de Jaume Roig, no nos dice si son versos asonantados.

111 En esta época, en efecto, el romancillo de cinco sílabas conoce cierto auge. Véase $B A E$, t. 2 , pp. $2,4,5,605$; t. 61 , p. 420 ; t. 63 , pp. $18,23,122$, 124, 543. Los poetas, por cierto, no le dan ese nombre. Iglesias de la Casa ("La palomita") y Meléndez Valdés ("Regalando unos dulces a una señorita de pocos años", etc.) lo llaman letrilla; Moratín padre ("La barquerilla", etc.), anacreónticas; Moratín hijo, simplemente romance; en Arjona se trata de un himno "A Jesús en el sepulcro", y en Iriarte, por supuesto, de fábulas ("El naturalista y las lagartijas", "La berruga, el lobanillo y la corcova"). No he creído conveniente alargar mi Catálogo incluyendo estos casos en sus lugares respectivos.

112 Sor Juana emplea el romance octosílabo abundantemente, tanto en las poesías como en el teatro (es un metro que nunca ha tenido eclipse). Me limito a llamar la atención sobre los núms. 218 y 245 , que están en latín de breviario, y el 258, que está en latín macarrónico. - Los romances hexasílabos abundan también: núms. 70 a 74, 221, 224, 235, 241, 244, 252, 264, 266, 269, $271,274,284,294,300,313,322,324,341,356,360,365, x x, x x v i i i, x x x i, x x \times v$. Algunos tienen designación: endechas castellanas $(360)$, folias $(x x)$, rocotín $(224,241)$, cardador $(71,266)$ (para otro cardador véase infra, \$ 107). Los hay en latín $(252,266,360)$, en "negro" $(224,274, x x x i)$, en náhuatl (224) y en una mezcla de español y náhuatl (241). - Los romances heptasílabos son los menos frecuentes: núms. 67 (con la designación panamá), 75 a 79, 336, xiii, xviii, xxiii, lxxi; y en el teatro: t. 3, pp. 43-47, 145-146, 176-178, 181-183, 425-426; t. 4, pp. 63-64, 116-117, 185-186. 
... ser esposa de Narciso

quise, e intenté, soberbia,

poner mi asiento en su solio

e igualarme a su grandeza,

juzgando que no

era inconsecuencia

que fuera igual suya

quien era tan bella;

por lo cual él, ofendido,

tan desdeñoso me deja... [etc. $]^{113}$

[ $\$ 97]$ En su citado artículo de $R P h$, Tomás Navarro destaca "la inclinación de Sor Juana a ensayar formas originales o poco conocidas en la versificación de su tiempo..., ante todo el decasílabo dactilico con principio esdrújulo" en dos poesías, núms. 61 y 62, "ambas asonantadas en forma de romances". (o sea, simplemente, que son romances).

La primera de esas dos poesías lleva un epígrafe en el cual se explica que allí la autora "pinta la proporción hermosa de la... Condesa de Paredes, con otra de cuidados, elegantes esdrúxulos que aún le remite desde México a Su Excelencia". O sea: pinta una hermosa proporción con otra: con un retrato para el cual quisiera Sor Juana la armoniosa proporción del cosmos:

Lámina sirva el cielo al retrato, Lísida, de tu angélica forma; cálamos forme el sol de sus luces; silabas las estrellas compongan...

Es un retrato hecho con amor. Es, en verdad, un poema erótico ${ }^{114}$.

113 Véanse también otros dos breves pasajes del t. 3: pp. 257-258 (romance octosílabo terminado en romance hexasílabo con la misma asonancia, a semejanza del "Hortelano era Belardo..." de Lope) y 272-275 (romance hexasílabo, de asonancia $\dot{e}-a$, entreverado en uno octosílabo de asonancia $\dot{e}-$ o). En su nota al pasaje de $E l$ cetro de José (pp. 609-610), A. M. P. cita el antecedente de Calderón registrado supra, $\$ 30$, que más bien se aplicaría al ejemplo que veremos en el $\S 125$. En cuanto al pasaje de $E l$ divino Narciso, observa (p. 519) que los hexasílabos "se imprimen las más veces, en los viejos textos, como una pareja de dodecasílabos", pero da buenas razones para concluir que "en la intención rítmica" de Sor Juana son hexasílabos.

114 La misma mano que hizo el epígrafe antes citado había hecho antes esta "Advertencia" en el núm. 16, una de las primeras poesías dedicadas a la Condesa de Paredes (María Luisa Manrique de Lara y Gonzaga, mujer del Marqués de la Laguna, Tomás Antonio Manuel Lorenzo de la Cerda y Enríquez Afán de Ribera, virrey que fue de la Nueva España de 1680 a 1686): "O el agradecimiento de favorecida y celebrada, o el conocimiento que tenía de las relevantes prendas que a la señora virreina dio el cielo, o aquel secreto influjo (hasta hoy nadie lo ha podido apurar) de los humores de los astros, que lia- 
Se "pintan" con morosa delectación, en otras tantas cuartetas, el pelo, la frente, las cejas, los ojos, la nariz, las mejillas, la boca ("búcaro de fragancias"), el hoyuelo de la barbilla... Y luego:

...tránsito a los jardines de Venus

órgano es de marfil, en canora música, tu garganta, que en dulces

éxtasis aun al viento aprisiona;

pámpanos de cristal y de nieve, cándidos tus dos brazos, provocan

Tántalos, los deseos ayunos:

míseros, sienten frutas y ondas... ${ }^{11 \pi}$

La "hermosa proporción" de este romance ha impresionado siempre a los lectores ${ }^{116}$. Y me parece muy probable que, por una especie de pudor, quienes han admirado esa poesía tan nueva y tan desusada -y tan alarmante para la gazmoñería de entonces y de ahorahan trasladado su admiración del contenido a la forma, del "mensaje" a la "estructura". Lo que elogia el neogranadino Álvarez de Velasco (cf. infra, \$ 136) es el primor de la hechura. "Nótese -dice Joseph Vicéns, el adicionador (1703) del Arte poética de Rengifoque inventó la Americana Poetisa, Musa Décima, un singular romance cuyos primeros vocablos son esdrújulos". Agustín Pérez de Castro, uno de los jesuítas dieciochescos desterrados a Italia por Carlos III, ilustró con notas, según su biógrafo y hermano en reli-

man simpatía, o todo junto, causó en la Poetisa un amor a Su Excelencia con ardor tan puro, como en el contexto de todo el libro irá viendo el lector". Y en efecto, el lector no puede menos de irlo viendo, y de algo podrá haberle servido la "Advertencia". Ese entusiasmo, ese énfasis de Juana Inés cuando se dirige a Maria Luisa, ¿a qué se deberá? ‘a agradecimiento de poetisa aplaudida por una virreina? ¿a aprecio intelectual? ‘a... amor? Tal vez a "todo junto".

115 De los varios y muy pertinentes textos de poetas anteriores que cita A. M. P. en sus anotaciones -por ejemplo, Góngora: los tiernos pechos de Tisbe "de los jardines de Venus / pomos eran no maduros"- destacó éste, en prosa, de Gabriel de Bocángel: "Si me mandasen pintar al Amante, dibujaría yo a Tántalo, el cual... siempre quiere alcanzar la manzana y beber, pero nunca bebe ni alcanza". Pero la cuarteta más risquée es la que se refiere a la cintura, "Bósforo de estrechez", ceñida por un "breve cíngulo" tal como el orbe celestial está ceñido por sus zonas o círculos, y donde el rico vestido es una clausura rígida (aunque de seda) que "músculos nos oculta ambiciosa". (Hay que observar que cuando se escribió esta poesía doña María Luisa contaba unos 40 años, dos más que Sor Juana, y que había tenido por lo menos tres partos).

116 El núm. 62, "Celebrando los años de un caballero" (desconocido), tiene exactamente la misma disposición, y es, a ojos vistas, una poesía de cumplimiento, para la cual podía usarse un molde ya "garantiado", de éxito seguro. A estos dos ejemplos cabe añadir un tercero, muy breve, en la "Loa a los años de la Reina madre" (t. 3, p. 400): "Puesto que ya, en sus cuatro deidades, / vínculos de los cuatro elementos..." (donde habrá que leer Puéstoque, como esdrújulo). 
gión Juan Luis Maneiro, esa poesía de Sor Juana, escrita en un nuevo metro, por ella inventado ("novo metro... quod ipsa primum invenerat"). Entre quienes la consideran inventora de ese metro se cuentan también Pedro Henríquez Ureña, Ermilo Abreu Gómez (sorjuanista mexicano) y, antes de ellos, Marcelino Menéndez Pelayo ${ }^{117}$. A diferencia de T. N. T., que parece no querer comprometerse (p. 263: "Por el renombre de Sor Juana y por la mayor extensión e importancia de sus ejemplos, ha sido corriente atribuir a esta escritora la invención del referido metro"), BAEHR afirma taxativamente (p. 133) que "la variante dactilica" del decasílabo (cf. supra, $\$ 20)$ fue "empleada por primera vez por Sor Juana Inés de la Cruz como verso autónomo".

En realidad no es así. El famoso romance decasílabo de Sor Juana -obsérvese cómo nadie se acuerda del otro (núm. 62) puede ser de 1688 como puede ser de 1689 , de manera que puede habérsele anticipado el bachiller y presbítero Gabriel de Santillana (supra, \$ 89) ${ }^{118}$. Pero, además, ya se habian escrito romances exac-

117 Todos estos datos proceden de A. M. P., SJ, t. 1, pp. 456-459. El caso de Menéndez Pelayo es curioso. Elogia a Sor Juana cuando -en opinión de él- deja de pertenecer a su tiempo y da la impresión de haber vivido en otro "mejor". Hay en El divino Narciso -dice- canciones "tan bellas... y tan limpias, por lo general, de afectación y culteranismo, que mucho más parecen del siglo xvi que del xvn, y más de algún discipulo de San Juan de la Cruz o de fray Luis de León que de una monja ultramarina", pues ¿quién iba a imaginar que algo bueno saliera de una monja, que además ni siquiera era peninsular sino "ultramarina", y que, colmo de los colmos, imprimía sus versos "con el rótulo de Inundación castálida", chorreante de mal gusto? (Historia de la poesia hispano-americana, ed. de Santander, 1948, t. 1, p. 75). Pero se muestra totalmente excédé por el romance decasílabo dedicado a la Virreina. El jesuíta Diego Calleja (si en efecto es él, como creen Menéndez Pelayo y A. M. P., el autor de la "Elegía" en tercetos publicada en 1700 en la Fama y obras pósthumas...) había dicho que la monja mexicana "nuevos metros halló, nuevos asuntos". Y don Marcelino comenta: "En cuanto a metros nuevos, paréceme que Sor Juana inventó uno solo, más curioso que recomendable", y cita los versos dedicados a la Condesa de Paredes. (Con qué atención los leyó, se ve por el nombre que les da: "versos sueltos". ..!). No contento con eso, aprovecha la oportunidad para unir en una pelota su odio al Barroco español y su desdén por Rubén Darío y adláteres: "Acaso si algún vate modernista tropieza con ellos, se anime a imitarlos" - como en efecto han hecho Amado Nervo («so nomás": "Página primordial de la vida, / trémulos parpadeos del alba...") y Gabriel Méndez Planearte, hermano de Alfonso ( A Sor Juana»: "Lámparas no de Psique pagana, / místico si temblar de luceros, / diáfanos son tus ojos, diamantes / fúlgidos, pensativos y negros...").

118 Recuérdese el epigrafe o inscripción del romance: “... elegantes esdrújulos que aún le remite desde México..." O sea: la Condesa está ya de regreso en España, y Sor Juana aún le manda versos. El marido de la Condesa había transmitido "el bastón virreinal al Conde de la Monclova... el 30 de noviembre de 1686, aunque aún permaneció aquí [en la ciudad de México] hasta el 
tamente del mismo tipo en México, en 1673 (\$ 37), y en España, en 1687 (\$ 87). El decasílabo dactilico estaba ya en circulación como "verso autónomo". A. M. P. vio muy bien que Sor Juana, gran inventora de metros nuevos, no lo había sido de éste. Pero, comprensiblemente empeñado en darle todas las glorias posibles, descalifica al bachiller Ribera $(\$ 37)$ porque el verso 2 no sigue del todo bien el esquema, argumenta que fue Sor Juana quien "estilizó como metro culto" el romance decasílabo (como si la "estilización" de Santillana no fuera suficiente), y añade que ella "le infundió vida más definitiva con su aliento exquisito" (loe. cit., p. 458). En cuan to a esto último, no hay duda. Y seguramente nadie se opondría a su sugerencia de que las métricas españolas lo llamen decasilabo sorjuanino.

Cuando Gerardo Diego, en su Antología poética en honor de Góngora (Madrid, 1927), tuvo que decidirse por una poesía de Sor Juana, que "dejó señales tan expresivas de su devoción para Góngora como su poema alegórico El Sueño", desdeñó "los versos enrevesados de ese poema" y, después de dudar entre "otros más decorativos y luminosos, en que el ingenio de la monja resplandece en sabrosos hallazgos", se decidió por nuestro romance decasílabo. "El retrato de la Condesa de Paredes - dice (op. cit., pp. 52-53) hará retroceder a más de uno. Olvídese el duro artificio de los esdrújulos. O mejor, no se olvide, puesto que el poeta lo ha querido así, y ha de obtener de tan estrecho y violento ritmo, elásticos, escultóricos efectos. La máxima realidad de un género, el retrato, vencida victoriosamente por la máxima irrealidad, por el supremo, escandaloso artificio de una técnica poética y estrófica. Buena lección de Góngora que Sor Juana adapta a las exigencias simetrizantes, barrocas de la época. ¿Hay algo más parecido al espíritu, a la forma de la ornamentación barroca de retablos y fachadas que estrofas como ésta ["Tránsito a los jardines de Venus...", etc.], en la que cada verso se monta sobre el inicial esdrújulo del siguiente en un ascensional alarde de torneada arquitectura, tan idónea, después de todo, a la delicia escorzada del modelo?"

25 de abril de 1688" (A. M. P., SJ, t. 1, p. 378), fecha que, un poco irrealmente, podemos tomar como terminus a quo (y como terminus ad quem, por si hace falta, el 20 de agosto de 1689, fecha de la aprobación de la Inundación castálida). La fiesta de la Natividad de la Virgen, para la cual escribió Santillana su romance de 1688, cae el 8 de septiembre. A. M. P., ibid., o. 456, después de mencionar éste, se pregunta con énfasis, subrayando los verbos: " $I m i$ tó o precedió a Sor Juana?" Pero (me pregunto yo) en caso de que para agosto estuviera ya escrito el romance de Sor Juana, des verosímil que Santillana haya tenido acceso al manuscrito? Me parece mucho más natural lo contrario: Sor Juana conoció los versos de Santillana en septiembre, y en septiembre mismo pudo escribir los suyos. (A. M. P., por cierto, no conoce los de 1687 que cito en mi $\$ 87$ ). 
[\$ 98] Entre las poesías en endecasílabos de Sor Juana, dice T. Navarko en su art. cit. de $R P h, 1953$, p. 45, se encuentran "dos de las primeras muestras conocidas de romance endecasílabo o heroico". A lo cual cabe objetar que esas muestras son más de dos, y que, como habrá ido viéndose en el presente Catálogo, no son ciertamente "de las primeras" 119 . Además de los dos del párrafo siguiente, Sor Juana escribió los siguientes romances de once sílabas: núms. 272, 308, 315 y vii, y el comienzo de una "Loa a los años del Rey", de $1684^{120}$. Cito un fragmento de esta última porque tiene la particularidad de estar escrita, como los romances de Góngora y Lope que figuran al comienzo del Catálogo, no en cuartetas, sino en octetas, separadas entre sí por un estribillo (t. 3, p. 359):
A los años alegres y festivos
del soberano, el invencible Carlos, concurren las estrellas con sus luces, concurren los planetas con sus rayos mostrando, en el concilio de luceros que hubieron menester para formarlo,

119 La objeción debe habérsela hecho el propio Navarro, que en su $M e^{\prime}$ trica, p. 241, aumenta en uno el número de las "muestras" y no dice que sean "de las primeras" (si bien cita sólo a Valenzuela [cf. infra, § 143] y a Sor Juana, en ese orden). Cito su frase de 1953 porque de ella arranca, en verdad, el presente artículo. En 1960 la tenía grabada en la memoria cuando tuve ocasión de hojear o leer, en las espléndidas bibliotecas de la Hispanic Society of America y de la Boston Public Library (Ticknor Collection), las "academias" y demás rarezas poéticas del siglo xvu que adornan mi Catálogo. Al ver la frecuencia con que aparecía el romance endecasílabo en tiempos anteriores a Sor Juana, comencé a partir de cierto momento a tomar apuntes. Aunque me constaba que éstos eran insuficientes, tuve la idea de escribir una nota breve - "Sobre la cronología y los nombres del romance de once silabas", o algo así-, de posible utilidad para posibles interesados. Naturalmente, nunca la hice. (La otra vertiente de posible interés en mi largo artículo de ahora, o sea la que se refiere a las variedades estróficas del romance "barroco", apareció mucho más tarde, en el Fall Semester de 1974/75 en la Universidad de Princeton, cuando me di el gusto de leer con atención, por vez primera, toda la obra de Sor Juana, so pretexto de un Graduate Seminar dedicado exclusivamente a ella).

120 Es ésta la fecha segura más antigua. (El núm. vii es de 1677 , pero no está bien probado que sea de Sor Juana). En nota al núm. 272 (de 1685) dice de manera curiosa A. M. P.: "Métricamente, son de advertirse en Sor Juana este y otros ejemplos de romance endecasilabo, que suele creerse innovación del siglo xvm", -como sugiriendo, muy sottovoce desde luego, que la innovación podría ser de Sor Juana. Y Dorotrry Glotelle Clarke, gran experta en cuestiones de métrica, dice del romance heroico: "Apparently not used in the Golden Age proper, but found in the works of Sor Juana Inés de la Cruz and listed in the 1703 edition of Rengifo's Arte poética española", o sea en las adiciones de Joseph Vicéns (PMLA, 67, 1952, p. 418 nota). 
el estudio de todas las estrellas, de todo el cielo el especial cuidado...

[\$ 99] El segundo de los "Bailes y tonos provinciales de un festejo, asistiendo en el monasterio de San Jerónimo los Excmos. señores Condes de Paredes, virrey y virreina de México" (núm. 65) se llama turdión, nombre de una danza aristocrática, bien documentado en su nota por A. M. P., el cual concluye diciendo que "métricamente, aquí, no es sino [un nombre del] romance real, o endecasílabo". El nombre del turdión y ese mismo metro reaparecen en el Coro 4 del "Sarao de cuatro naciones, que son españoles, negros, italianos y mexicanos", con que termina la comedia de Los empeños de una casa (t. 4, pp. 182-183). El primero comienza: "A las excelsas, soberanas plantas / del soberano, esclarecido Cerda..."; y el segundo: "Al invencible Cerda esclarecido, / a cuyo sacro culto reverente..."; pero, por lo demás, son muy distintos ${ }^{121}$.

[\$ 100$]$ Uno de los ejemplos de "habilidad técnica" que destaca T. Navarko en su artículo es el labyrinto hendecasyllabo (núm. 63), formado "por versos de triple medida que incluyen tres romances, de seis, ocho y once sílabas, cada uno de los cuales hace sentido dentro del conjunto a la vez que puede leerse independientemente". A. M. P. cita en su anotación el precedente de Salazar y Torres (supra, $\S 46)^{122}$. El ejemplo de 1687 que he añadido en el $\S 88$ es también anterior al "laberinto" de Sor Juana. Navarro siente que "en realidad... sólo la versión hexasílaba, base indudable de la composición, figura como forma propia y natural", observación contraria a la que he hecho yo a propósito del "laberinto" de Salazar y Torres. El de Sor Juana está mejor trabado y, aunque sintácticamente complejo, es mucho más fluido $\mathrm{y}$, sobre todo, responde mejor al reto de las tres lecturas. Véase el comienzo (habla en él la Condesa de Calve, felicitando por su cumpleaños al marido, que fue virrey de 1688 a 1696):

$$
\begin{aligned}
& \text { Amante, - caro, - dulce esposo mío, } \\
& \text { festivo y - pronto - tus felices años } \\
& \text { alegre - canta - sólo mi cariño, } \\
& \text { dichoso - porque - puede celebrarlos... }
\end{aligned}
$$

121 En el coro del "Sarao" se rompe a favor de la Condesa de Paredes la simetría enumerativa: al virrey se le da una cuarteta, a la virreina dos (muy floridas, como todo), y a José, el fruto "mexicano" de la pareja, otra vez una. (José tenía entonces tres meses de edad: cf. la introd. de A. G. Salceda, continuador de A. M. P., al t. 4, pp. xvii-xviii) .

122 Y rechaza el del Estebanillo González aducido por Abreu Gómez, que no es sino un soneto con doble acróstico. (Tengo la impresión de que una búsqueda sistemática aumentaría el número de estos romances-laberintos). 
[\$ 101$]$ Con este número se inicia el desfile de las muchas combinaciones estróficas del romance que, adoptadas o introducidas por Sor Juana, abundan extraordinariamente en sus obras. Esta primera (núm. 254) está en cuartetas de 6-6-6-11:

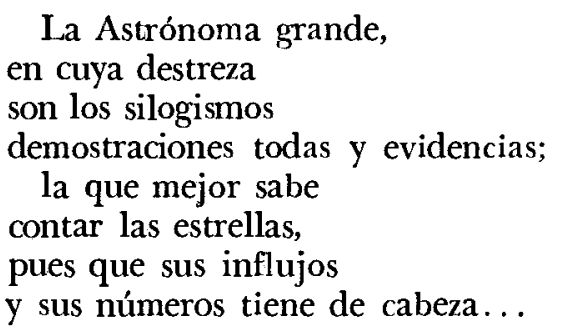

T. Navarro, art. cit., p. 45, explica este esquema como "efecto de la fusión de la nueva endecha real con la sencilla endecha hexasílaba de la tradición castellana". Pero, aparte el hecho de que la "endecha real" no era tan nueva, pues venía practicándose por lo menos desde Trillo y Figueroa ( $\$ 14$ ), yo pondría el esquema de Sor Juana en el contexto de un afán experimentador mucho más amplio, en serie con todo lo que sigue.

[\$ 102] La "endecha real" misma (cuartetas de 7-7-7-11), dice NAVARRo, ibid., nota 3, "fue usada por Sor Juana en "Divina Lisi mía" y en "Qué bien, divina Lisi»". Y también -añado yo- en los núms. $289,295,305,316,338,348$ y xliv, así como en varios pasajes de obras teatrales: t. 3 , pp. $122-123^{123}, 248-249,250-252,316-317,386-$ 387, 402-403, 418-421, 438-440; y t. 4, pp. 19-21. En un caso (t. 3, pp. 396-397) los heptasílabos son esdrújulos:

Atended, y no equívocos

estéis, y pues es áncora

a los discursos náufragos,

mi voz sonora os sacará a la playa...

[\$ 103] Curiosamente, las únicas "endechas reales" mencionadas por Navarro (núms. 82 y 83) no se llaman así en la edición original, sino romances endecasílabos, "nada apropiadamente -comenta A. M. P., t. 1, p. $483-$, puesto que se componen de $7,7,7$ y 11 ". Pero en tiempos de Sor Juana la designación se sentía obviamente como apropiada, y romance endecasilabo se llaman, por ejemplo,

123 En este pasaje (del auto de San Hermenegildo) podría verse, como hace A. M. P. en el "Índice antológico" del t. 3 (p. 733), unas "endechas reales irregulares", de 7-7-7-11 + 4-10 (algo parecidas, pues, a las del $\S 113$ ). Yo prefiero no multiplicar los entes, y las considero simples endechas reales con estribillo. 
las endechas reales de Ovando y Santarén ( $\$ 58$ y 90) ${ }^{124}$. Los dos romances de Sor Juana están dirigidos a doña María Luisa, la Condesa de Paredes; cito el final del segundo, donde el lector descubrirá la coincidencia con uno de los más bellos sonetos de amor de la monja:

...Baste ya de rigores,

hermoso dueño, baste;

que tan indigno blanco

a tus sagrados tiros es desaire.

[\$ 104] En el núm. 274, al final, hay un breve romance en coplas irregulares, cuyo paradigma podría ser $8-8-8-5$, si bien el último verso es fluctuante ${ }^{125}$. Tengo la impresión de que Sor Juana se inspiró en las coplas anónimas que cité en el $\S 19$. La "media lengua" de las coplas (efecto grotesco) corresponde allá a la media lengua de un borracho, acá a la de un vizcaíno:

Juras a Dios, Virgen pura, de aquí no te has de apartar; que convenga, no convenga, has de quedar...

[\$ 105] Un trecho en coplas de romance de 8-8-10-10 puede verse en la "Loa al año que cumplió el señor don José de la Cerda, primogénito del señor virrey Marqués de la Laguna" (1680), t. 3, pp. 450-451:

...Porque este Faetón, que a rayos

parece que el orbe hiere,

es José, que en un año de vida,

de beldades mil siglos contiene... ${ }^{126}$

[\$ 106] En dos ocasiones hizo Sor Juana romances en cuartetas de 7-5-7-5, o sea el metro de las "seguidillas regularizadas": núm. 288 y "Loa a los felices años del señor virrey Marqués de la Laguna"

124 A. M. P. cita a continuación las palabras de Vicéns, el adicionador (1703) de Rengifo: las de 7-7-7-11 se llaman "endechas endecasílabas, porque constan de algún pie de 11 , que ordinariamente es el cuarto verso de cada copla". Es el nombre que hemos visto en los $\$ \S 63$ y 66 . En las "tablas" con que termina mi trabajo podrá verse, por una parte, lo que abarcó la designación romance endecasílabo, y por otra los nombres que tuvo la endecha real.

125 La copla que voy a citar es la segunda; en la primera, el verso 4 tiene seis sílabas; en la tercera y en la cuarta, cuatro.

126 "Romance polimétrico" lo llama A. M. P., "fndice antológico" del t. 3, p. 235, quizá porque una vez el v. 3 es de once sílabas; y cuatro veces, el v. 4 es de doce. (Las coplas son nueve). 
(t. 3, pp. 423-425). Pero no se trata de seguidillas, sino, como dice A. M. P. en nota al núm. 288 , de "un romance que continuadamente alterna versos de 7 y 5 ". Es casi seguro que el nombre que se daba a estas coplas era endechas ${ }^{127}$ :

\section{El retrato del Niño}

mírenlo uscedes, y verán cosas grandes en copia breve.

De oro y plata en listones un ramillete de encarnado es, y blanco, de azul y verde...

He dudado si considerar en párrafo aparte la forma del núm. xxxviii:

Quae est ista, quasi aurora?

¡Miren, miren qué gracia!

Es la aurora María

que se levanta

cual varilla de humo

con mil fragancias.

Suba, suba la reina, venga la amada,

que la risa del día

le toca al alba...

Son cuatro estrofas de esta hechura, pero los versos 1-2 pueden tomarse más bien como estribillo (el v. 2 dice siempre "Miren, miren qué gracia" y el v. 1 es siempre un texto litúrgico).

[§ 107] En cambio, he decidido arbitrariamente consagrar un párrafo aparte al núm. xlvi, llamado cardador. Su métrica es irregular, pero, de manera muy arbitraria también, se puede decir que está hecho en cuartetas de 6-5-6-5, metro de seguidillas que en 1684 (fecha de esta composición) no era ya usado; y además, muestra también las fluctuaciones que la seguidilla tenía en la época de Lope (cf. el $\S 4$, con sus notas).

[\$ 108] Dice Tomás Navarro en su Arte del verso, México, 1959, p. 76: "Heptasílabo y hexasílabo se asocian con dificultad. Fue que-

127 Es, por ejemplo, el que se da al núm. 80 (cf. nota de A. M. P.). Pero en el núm. 80 -como en los núms. 277, 297 y $311-$, aunque haya continuidad en el tema, no la hay en la asonancia, de manera que allí se trata de auténticas seguidillas. Cf. Lope de Vega, supra, p. $\mathbf{3 7 0}$ y nota $\mathbf{5 9}$. 
dando excluida [a lo largo del siglo xviI] la combinación 7-6-7-6 de las antiguas seguidillas". En la composición citada en el párrafo anterior hay una copla de 7-5-6-6 y otra de 7-5-7-6. En cambio, la núm. $l \times x x i i$ muestra una gran regularidad en sus doce coplas de 7-6-7-6:

... Mas si ya a los poetas

su lechuga falta, no será sin lechuga

buena la ensalada...

(Hay que añadir que este romance va entreverado, sin ley precisa, con otro octosilábico y de distinta asonancia).

[§ 109$]$ El núm. lxyiii es un romance hecho en coplas de 8-6-8-6:

... Quien a su sombra benigna

alegre sanó,

quedó muy bien asombrado

pero sin lesión.

[§ 110] Varias veces (y no una sola, como se deduciría de las palabras de T. N. T., p. 264) empleó Sor Juana para el romance el esquema de 10-12-10-12 que ya conocemos a partir del "Mari-Zápalos" de Camargo (§ 12). Así en el núm. 265, sobre la negación de San Pedro:

...Desatado en raudales el pecho,

en fuentes perennes vierte el corazón;

e inundando en cristales sus penas,

anega con llanto lo que antes negó...

Así también en los doce versos finales de El divino Narciso (t. 3, pp. 96-97) y en un largo pasaje del "Sarao de cuatro naciones", versos 118-157 (t. 4, pp. 179-180). (Cf. también el estribillo del núm. $l x v$, y la nota de A. M. P.).

[\$ 111$]$ El "Sarao de cuatro naciones" que acabo de mencionar se relaciona mucho con la suite de "Bailes y tonos provinciales" citada en el $\S 99$. Uno de estos "Bailes" (núm. 66) recibe el nombre de españoleta. Está hecho en el mismo metro de 10-12-10-12, y su materia es la misma que la del pasaje del "Sarao". Compárese el comienzo de éste - "En el día gozoso y festivo / que humana se muestra la hermosa deidad / de María..." (o sea María Luisa, la condesa de Paredes) - con el de la españoleta, donde, por cierto, como hemos visto que ocurre en otros casos, reaparece la asonancia misma del "Mari-Zápalos": 
Pues la excelsa, sagrada María, humana y benigna quiere reducir todo el sol a una esfera tan corta, todo el mayo a un pequeño pensil... ${ }^{128}$

[\$ 112$]$ Finalmente, las coplas de 10-12-10-12 reciben en el núm. $i x$ el nombre de canario, que debe haber sido una danza muy alegre y movida ("El canario que suena festivo, / pagado y contento de buenos pasajes...").

[§ 113] Después de referirse a las endechas reales de Sor Juana, menciona T. Navarro, art. cit., p. 45, "otra especie de endechas, sólo empleadas al parecer por la monja mexicana, en las que cada cuatro versos de siete sílabas van seguidos por uno de diez, compuesto de dos adónicos" ${ }^{129}$. En realidad, este esquema (7-7-7-7 + $10)$ aparece ya en Salazar y Torres $(\$ 43)$. La composición de Sor Juana (núm. 81) recibe en las ediciones antiguas el nombre de endechas irregulares, que A. M. P. cambia en la suya por otra ciertamente más precisa: "Endechas de siete y diez". Copio la primera y la última quíntetas de esta bella poesia, "Afectos de un favorecido que se ausenta":

Divino dueño mío:

si, al tiempo de apartarme, tiene mi amante pecho alientos de quejarse, oye mis penas, mira mis males...

...Y puesto que me ausento, por el último vale te prometo, rendido,

128 En cuanto al nombre de la españoleta, A. M. P. reproduce (nota del núm. 66) algunos de los datos de Cotarelo, introd. del t. 17 de la NBAE, p. coxliv. No parece que el baile estuviera asociado con una métrica determinada, si bien la españoleta de El juicio de Paris de Zamora (1716), parodia de "Arrojóme las naranjicas", no anda muy lejos: "Arrojóme el señor Cupidillo. / las saetas que flecha veloz..."

129 En nota añade Navarro "la [endecha] de cuatro heptasilabos y un decasílabo aconsonantados, abbaA", forma que, en mi opinión, más tiene que ver con la métrica italianizante que con la castellana de la endecha. En su Métrica española, p. 266, dice: "Dos poesías [de Sor Juana, núms. 263 y lxvii]... presentan una combinación de endecha real y sexteto, en la que aparece un tercer verso de pie quebrado que repite a manera de eco la rima del segundo heptasílabo". De hecho, estas poesías -que no son dos, sino cinco (agréguense los núms. 251 y 312 y la intercalada en El divino Narciso, vs. 1173-1208) están compuestas en estrofas de versos consonantes, no asonantes. Ya he recordado (supra, p. 380, nota 79) la definición que da T. N. T. de la endecha real: "romance heptasílabo en que...", etc. 
mi amor y fe constante,

siempre quererte, nunca olvidarte.

[§ 114] En el núm. lvi, el verso supernumerario de la cuarteta heptasilábica no tiene diez sílabas, sino doce:

Escuchad los suspiros, escuchad, Virgen bella, los sollozos más dulces entre lágrimas tiernas, con que, el partiros, el orbe se lamenta...

A diferencia de la combinación anterior, donde el decasílabo es siempre suma de $5+5$, aquí el dodecasílabo sólo en tres coplas es suma de $6+6$ ("la partida lloran de su hermosa reina"...) ${ }^{130}$.

[\$ 115$]$ En el núm. 331 nos encontramos, como dice en su nota A. M. P., con una "armoniosa combinación" (no cita la también armoniosa de Góngora, $\S 3$ ) de 8-8-8-8 + 6-6:

Esta fábrica elevada, que parto admirable es de los afanes del arte, del estudio del nivel, aunque es $\tan$ hermosa, la mejor no es...

(Hay, además, un tetrasílabo de enlace entre copla y copla, con la misma asonancia y con palabras distintas cada vez).

[§ 116]. De la combinación que aparece en el núm. 314 (8-8-8-8 + 7-5) no dice A. M. P. que sea "armoniosa" (de hecho, no hace comentario alguno). Su armonía, en efecto, no es muy aparente:

Un áspid al blanco pecho aplica amante Cleopatra. ¡Oh, qué excusado era el áspid adonde el amor estaba! ¡Ay qué lástima, ay Dios, ay qué desgracia!...

El seno ofrece al veneno la valerosa gitana, que no siente herir el cuerpo

130 Esta particularidad desconcierta bastante a A. M. P., el cual, como confiesa en nota, se vio muy tentado a meter mano para corregir los dodecasilabos irregulares. 
la que tiene herida el alma;

que en quien lo más perece,

lo menos falta...

[\$ 1117$]$ En la primera jornada de la comedia Amor es más laberinto, versos $1005-1050$ (t. 4 , pp. 244-245), hay un pasaje de romance en coplas de 8-8-8-8 + 4-12:

¿Qué es aquesto, cielo injusto?

¿Qué es lo que pasa por mí, que lo acierto a padecer y no lo sé definir?

¡Ay de mí,

que mal sabe hablar quien sabe sentir!

Apenas, Amor tirano,

de tus flechas conocí

que las hace más agudas

quien las quiere resistir, cuando vi

que sabes hacer más daño que herir...

El quebrado tiene siempre la asonancia $i$, y el dodecasílabo es siempre suma de $6+6$.

[\$ 118 La "Loa a los años de la reina madre doña Mariana de Austria", de hacia 1690, nos ofrece (t. 3, pp. 400-401) un pasaje de romance en coplas de 8-8-8-8 + 8-12:

Silbos os ofrece el viento, auras consagra lascivas, ecos os dedica amante, plumas lo otorgan festivas: silbos, ecos, auras, plumas ofrecen, consagran, otorgan, dedican.

Aquí, los dos últimos versos son siempre recapitulativos, y el dodecasílabo es siempre bipartito.

[\$ 1119$]$ En el núm. 303 encontramos coplas de 8-8-8-8 + 4-6-6:

A poder Dios hacer otro

Dios, tan bueno como Él, a lo que imagino yo, hiciera sólo a Josef;

$y$ se ve, pues en cuanto pudo le dio su poder... 
Aquí, y en los cinco párrafos siguientes (hasta el 124), la cuarteta, regular o irregular, va seguida de tres versos, el primero y el tercero de los cuales adoptan la asonancia de los pares. Cf. la observación final del $\S 6$, supra.

[§ 120] El esquema del núm. lxix es más complejo (8-8-8-8 + 4-7-5):

Lo que a Juan y Diego niega

le concede Cristo a Pedro:

¡oh, cuánto debe de ser

de Pedro el merecimiento!

$\mathrm{Y}$ es muy cierto,

pues le dan lo que niegan

a Juan y Diego...

[§ 121] Las coplas de los núms. 288 y 352 están escritas con el esquema 8-8-8-8 + 5-7-5. También un pasaje del "Encomiástico poema a los años de la Condesa de Galve" (t. 3, pp. 417-473). Mi ejemplo procede del núm. 352:

Queriendo hacer un convite

la eterna sabiduría, para preparar la mesa antes la casa edifica, que a tal comida ha de ser nueva casa la que le sirva...

[§ 122] El núm. $l x x x$ está hecho en coplas de 8-8-8-8 + 5-8-8:

En amor, junto corria Pedro con Juan una vez, y atrás quedándose Pedro, igual no corrió con él;

y ya se ve que de amor la paridad no anduvo a todo correr...

[§ 123] El núm. 287 está hecho en "septetas" de 10-6-10-6 + 6-7-6. Es uno de los villancicos de la Navidad de 1689, de apariencia muy sencilla, pero de estructura compleja. Se trata en realidad de dos romances entreverados, uno de asonancia $i$ y el otro de asonancia $a$. Dice el primero:

Pues del cielo a la tierra, rendido

Dios viene por mí,

si es la vida jornada, sea el sueño 
posada feliz:

déjenle dormir,

y pues Dios por mí pena,

descanse por mí...

Y el segundo:

No se duerma, pues nace llorando,

que tierno podrá,

al calor de dos soles despiertos,

su llanto enjugar:

déjenle velar,

que es su pena mi gloria

y es mi bien su mal...

Esta bellísima composición ${ }^{131}$ está escrita para dos voces. Es fácil imaginar que las dos se repartían alternadamente las cuartetas octosilábicas y luego se reunían para cantar los tres versos finales, más una repetición del "Déjenle dormir", "Déjenle velar". (Même jeu en el estribillo, doble también: "Pues mi Dios ha nacido a penar, / déjenle velar"; "Pues está desvelado por mí, / déjenlo dormir"). Se tiene la sensación de una canción paralelística...

La estructura de las cuartetas es la misma que aparece en otro de los villancicos de la misma serie (núm. 285: "Sin farol se venía una dueña / guardando el semblante, / porque dice que es muy conocida / por las navidades") ${ }^{132}$, estructura llamada seguidillas reales en las ediciones antiguas, y que aquí son en efecto seguidillas, pues cambia la asonancia de una a otra ${ }^{133}$.

[§ 124] En el núm. 286 (villancico de la misma serie, o sea de la Navidad de 1689) las coplas son de 7-11-7-11 + 5-7-5:

131 Publicada primero, con los otros siete villancicos de la serie, en edición suelta de Puebla de los Ángeles, 1689 (sin mención de Sor Juana), y luego en las ediciones antiguas de obras de la monja, se atribuye sin embargo a Manuel de León Marchante en sus póstumas Obras poéticas, t. 2, Madrid, 1733 , p. 177, donde se dice que se cantó en Toledo en 1677. También se atribuyen a León Marchante otros dos villancicos de esa Navidad de 1689 y uno de Santa Catarina de 1691. La argumentación de A. M. P., SJ, t. 2, pp. 418419 (y antes en $P N$, t. 3, p. 70), en contra de tal atribución, me parece convincente.

132 También éste atribuido a León Marchante en sus Obras poéticas, t. 2, p. 172 .

$1 \% 3$ Cf. supra, $\$ 106$. Es raro que A. M. P. no haya hecho ninguna observación métrica en el núm. 287 ni en el 285, a pesar de que él mismo reproduce en el t. 2, p. xxii, unas seguidillas análogas de Pérez de Montoro: "...Cuenta que hay una grande cosecha / en Belén, de trigo; / y aunque hay parva que llega hasta el cielo, / el grano es chiquito..." 
...Moisés, que allá en un monte

cursó de leyes la mejor escuela,

hallándose con vara,

la toga pide, que feliz espera,

por que en él vean

que en vuestras leyes sólo

su ascenso encierra...

A cada una de las seis coplas contesta una segunda voz con un estribillo hecho de un decasílabo, siempre el mismo (y que mantiene la asonancia del romance: "Atended al decreto que lleva"), más una seguidilla de 7-5-7-5, de distinta asonancia cada vez ${ }^{134}$.

[§ 125] Coplas de 8-8-8-8 + 6-6-6-6 en el núm. 318:

Aquel tribunal antiguo

del legislador supremo,

en que dio en piedras escrita

dura ley a duro pueblo,

ya trueca en piadoso

el rígido ceño,

que aun los montes muda

el curso del tiempo...

Hay cinco coplas análogas en una de las "Loas" (t. 3, pp. 281 . 282). Ya Calderón había empleado este esquema (cf. supra, \$ 30). La misma alternancia de octosílabos y hexasílabos, pero sin la forma estrófica con que aquí se presenta, se ha visto supra, $\$ 96$.

[\$ 126] Coplas de 8-8-8-8 + 7-6-6-6 en el núm. 345:

-Está como muerto, porque

nos quiso, en este misterio,

de la fineza mayor

representar el recuerdo.

-Muy bien has respondido

134 En su nota, A. M. P. no hace ninguna observación métrica. En cambio, nos hace saber que este villancico "coincide literalmente con el IV de los -Villancicos que se cantaron en la Real Capilla la noche de Navidad del año de 1686», y que figuran en las Obras pósthumas de Joseph Pérez de Montoro (Madrid, 1737, t. 2, pp. 240-242) ... De por sí, merece más fe la reiterada inclusión en las obras de Sor Juana en 1691 y 1692 , viviendo ella, que no esa adscripción póstuma al poeta peninsular. $Y$ así, nos inclinamos a juzgar errada la fecha madrileña de 1686, y apócrifa la dicha atribución a Montoro. Un verdadero enigma de todas suertes". Para aclararlo, no está de más recordar que entre Sor Juana y Montoro hubo una verdadera admiración mutua, como puede verse por lo que dice el propio A. M. P. en $S J$, t. 1, pp. 364-365. 
a la duda, pero

no es por eso sólo,

aunque está bien eso...

(En las dos últimas coplas, el verso 6 es pentasílabo).

[§ 127$]$ Coplas, finalmente, de 8-8-8-8 + 7-5-7-5 en el núm. $x l i$ :

\author{
...Quisieron los galleguiños \\ meterse con su gaitero, \\ y en fiestas de cortesanos \\ no suenan bien los panderos: \\ os galegos no güelen \\ flores de oseo, \\ que no teñe Galicia \\ sino romeros...
}

Hasta la tercera de las coplas (que es la que he copiado), la asonancia $\dot{e}$-o abarca por igual la cuarteta octosilábica y la "seguidilla"; pero a partir de la cuarta copla el esquema se desbarata ${ }^{\mathbf{1 3 5}}$.

[ $\$ 127$ bis] Sor Juana Inés de la Cruz fue muy famosa. La admiración en que se la tuvo mientras vivía continuó intacta hasta muchos años después de su muerte, hasta el padre Feijoo y aun más tarde. (De hecho, nunca dejó de leerse a Sor Juana, aunque durante largo tiempo lo que se leyó fue el "Hombres necios que acusáis..." y poquita cosa más). Todo esto es evidente. En el plan de Alfonso Méndez Plancarte, el volumen final de su edición de Sor Juana debía incluir todo el material biográfico y laudatorio de las ediciones antiguas, y en particular del tomo tercero, el publicado en $1700 \mathrm{con}$ el título de Fama y obras pósthumas, más otras muchísimas muestras, poéticas sobre todo, de la admiración en que se ha tenido a la monja mexicana desde sus tiempos hasta los tiempos modernos. Iba a ser un volumen de tamaño considerable. Es una enorme pena que Méndez Plancarte haya muerto antes de tiempo. Los párrafos que siguen inmediatamente a éste podrán servirle a quien emprenda la edición de ese volumen final. Me alegra pensar que los datos que voy a añadir (v.gr. los de los $\$ \$ 132$ y 133 ) le hubieran interesado a Méndez Planearte.

Su edición de Sor Juana es verdaderamente ejemplar. Ningún

135 En las coplas cuarta y quinta, las cuartetas de octosílabos mantienen la asonancia $\dot{e}-o$, pero las "seguidillas" tienen, respectivamente, asonancia $\dot{e}-a$ y $\dot{a}-o$; en la sexta, la cuarteta rima en $\dot{a}-a$ y la seguidilla sigue rimando en $\dot{a}-o$; en la séptima y última, la asonancia vuelve a emparejarse, en $a \cdot o$. Se trata de un villancico "atribuible", pero tamaño desorden no me parece propio de Sor Juana. 
poeta español de los Siglos de Oro ha recibido un homenaje semejante ${ }^{136}$. Y el homenaje no fue sólo para Sor Juana: fue también, y generosa, exhaustivamente, para su época, para su ambiente, para la poesía que ella leyó, para los ideales morales y estéticos que la conformaron. Sor Juana no se alimentó sólo de Lope y Góngora, de Quevedo y Calderón. Se alimentó de muchos otros que si ahora son oscuros es sólo por culpa de la moderna pereza hispánica. "Pocos lectores modernos han repasado las obras de Rebolledo", dicen Wilson y Blecua (supra, \$22). Lo mismo se puede decir de... ¡tantos otros poetas! Méndez Planearte si los leyó. ¿Porque tenia obligación de dar un curso? ¿Porque iba a hacer fichas de enciclopedia, a tanto el renglón? No: porque le interesaba la poesía. ¡Y la halló!

Tan valiosa como su edición de Sor Juana es su antología de Poetas novohispanos. La vieja España no tiene nada que se parezca a ella. Y además, tanto para la primera como para la segunda se metió Méndez Planearte, y a fondo, en el mar vilipendiado (por desconocido) de la poesia española peninsular que va de la segunda mitad del siglo xvn a los primeros años del xvirr (la fecha límite de sus Poetas novohispanos es 1721). Y al dar cuenta de sus hallazgos les está diciendo a los críticos españoles (o, mejor, a los críticos de cualquier nacionalidad que se llamen a sí mismos amantes de la poesía escrita en español): "Miren, lean a Pérez de Montoro, a Salazar y Torres, a Manuel de León Marchante, a Eugenio Gerardo Lobo", a todos esos poetas a quienes las historias de la literatura, por inercia e ignorancia, condenan al limbo de la no-lectura ${ }^{137}$.

Pero, en fin, ne sutor ultra caligas! La veta de historia literaria que estoy siguiendo en este Catálogo lleno de diáfanas lagunas se

139 La única excepción podría ser Francisco de Medrano, cuya producción es, sin embargo, mucho más reducida y abarcable que la de Sor Juana.

137 En la poesía escrita en español, de cualquier tiempo que sea, pero particularísimamente de los Siglos de Oro y aun del xvir, yo percibo ante todo la unidad. A diferencia de ciertos compatriotas míos, no creo que Sor Juana nos pertenezca a los mexicanos (o que seamos los mexicanos los más obligados a leerla y a estudiarla y a escribir lo que sentimos de ella y de su ingenio). Pero, por otra parte, así como es natural que las mejores ediciones de Ronsard sean francesas y las mejores de Ariosto italianas - natural, o sea: es un hecho-, así también sería natural que las mejores ediciones de poetas españoles fueran obra de críticos españoles. Es explicable el malhumor de Menéndez Pelayo contra un Knapp, que se metió en un terreno que él hubiera querido acotar para sí mismo y para sus paisanos. (Lo cual no quita que las mejores ediciones de Torres Naharro, de Garcilaso y de Hurtado de Mendoza, para poner sólo tres ejemplos, se deban a hispanistas norteamericanos). Por eso, de alguna manera, el redescubrimiento de ciertos poetas españoles por parte de Alfonso Méndez Plancarte implica algún reproche a los críticos y Literarhistoriker españoles, tal como su llamado de atención sobre cierto romance del Conde de la Granja $(S J$, t. 1, pp. 441-442) implica algún reproche a los críticos peruanos. 
refiere sólo a la barroquización del romance ${ }^{138}$. Lo que pasa es que al hacer esta historia de una forma me he visto tan asaltado de tentaciones de meterme en la otra historia - la de la sensibilidad, digamos-, que algunas veces no he podido menos de sucumbir a ellas. En otras palabras: si no se había escrito antes la historia que estoy presentando en mi artículo ${ }^{139}$, es porque no se ha escrito la otra. Ha habido muchos estorbos para ello, pero ya es hora de eliminarlos. La obra de Menéndez Pelayo, "ingente", "grandiosa", etc., resulta sin embargo, a cada paso, uno de los estorbos más pertinaces. A los críticos flojos les hace perder la limpieza de juicio, y a los no flojos les hace perder el tiempo. Méndez Planearte, a pesar de su admiración por don Marcelino -o tal vez a causa de ella-, tiene que estar sacudiéndose a cada rato el plúmbeo peso de sus condenas, y también - trabajo más fácil- la pelusa de juicios y prejucios y lugares comunes menendezpelayescos que dejan caer "críticos" posteriores. Es obvio que don Marcelino no leyó mucho de lo que condena. Lo hizo ver Dámaso Alonso en un libro saludable que subtituló Las palinodias de don Marcelino. (Le propongo al lector curioso que compare las dos inteligentes y generosas páginas que Gerardo Diego consagra al poema heroico San Ignacio de Loyola de Hernando Domínguez Camargo, en su citada Antología poética en honor de Góngora, pp. 49-51, con los dos renglones, ni generosos ni inteligentes, que le escupe Menéndez Pelayo en su Historia de la poesia hispano-americana, ed. de Santander, 1948, t. 1, p. 424) .

El ejemplo de Sor Juana, dice Tomás Navarro, “influyó sin duda en otros autores mexicanos de fines del siglo xvn y principios del siguiente". Ya he llamado la atención (supra, § 95) sobre la necesidad de ampliar estas palabras. Hay que hacer una primera extensión, de los poetas mexicanos a los poetas de aquellas partes del Nuevo Mundo en que había vida literaria, y una segunda extensión, aún menos violenta que la primera, a los poetas peninsulares. A partir de 1690, todos los "consumidores" de poesía en lengua española vieron en Sor Juana una culminación, una cumbre no supe-

138 A veces dan ganas de que sean simultáneamente verdaderas las dos etimologías de barroco: el baroco escolástico, el argumento traído de los pelos, y el barrueco-barroco hispano-portugués, la perla "que se prolonga y se estira en un punto, hinchándose y casi quebrándose, pero sin estallar hecha pedazos" (Gilbert Highet, La tradición clásica, trad. A. Alatorre, México, 1954, t. 2, p. 7 y nota).

139 Lo digo con todo candor: a pesar de que los asuntos de métrica no son de ninguna manera mi "especialidad", la lectura de lo que dicen un T. N. T. o un BAEHR sobre la materia de mi artículo me ha hecho a menudo sentirme un pionero. $\mathrm{Y}$ no es que crea estar diciendo cosas muy trascendentales. El valor que tengan los datos de mi Catálogo será el que les dé cada uno de sus (hipotéticos) lectores. 
rada por nadie. (Y repito: son hechos evidentes) ${ }^{1 \neq 0}$. Esos admiradores, que ciertamente tenían gustos distintos de los nuestros y vivían en un mundo diferente, etc., etc., no eran ningunos tarados. Cuando Juan Ignacio de Castorena y Ursúa, en representación de los devotos mexicanos de Sor Juana, emprende en 1699 (cuatro años después de la muerte de la monja) su viaje a Madrid, lo que pretende es publicar, antes que un manojo de alabanzas (como la Fama pósthuma de Lope que había publicado Juan Pérez de Montalván), un tomo tercero, un volumen que debía aparecer "con el rótulo de Tercer parte y fama pósthuma de Sor Juana Inés de la Cruz" 141. Lo que quería, más que nada, era decirles “Aquii hay más!” a los ya fieles, y conseguir más lectores para una poesía que él y muchos como él admiraban. Y lo consiguió: el número de ediciones de los tres tomos que aparecieron en España entre 1700 y $1725^{142}$ es abso-

140 Véanse las poesías preliminares de los dos primeros tomos de Sor Juana en las ediciones antiguas; véase la Fama y obras pósthumas; véanse, en A. M. P., $S J$, t. 1, los núms. 48-51, con sus notas. Cuando $-\mathrm{a}$ unos diez años de la muerte de Sor Juana- redacta Francisco Álvarez de Velasco, bogotano, la portada de sus obras poéticas, Rhytmica sacra, moral y laudatoria, compuesta de varias poesias y metros, decide anunciarle al lector lo más atractivo que en ellas podrá encontrar; y lo más atractivo son dos cosas; la primera ". . con una epístola en prosa [ ¿de 75 páginas!] y dos en verso y varias poesías [diez en total, al parecer] en celebración de Soror Juana Inés de la Cruz"; y la segunda: “... una apología o discurso en prosa sobre la Milicia Angélica y Cíngulo de Santo Tomás". Este segundo aliciente nos deja perplejos (pero antes de reírnos de tal apologia deberiamos leerla); el primero, en cambio, es bien comprensible. De las dos epístolas en verso (las dos en silva), la primera parece estar dedicada al primer tomo de las obras de Sor Juana, y la segunda, escrita "en jocosas metáphoras", está dedicada expresamente al segundo; al segundo ("y especialmente a la silva del Sueño") está dedicado asimismo un romance; y hay un soneto en que Álvarez de Velasco, incapaz de decidir cuál de los dos tomos es el más bello, saca un extraordinario partido de su vacilación y halla "razones para, [declarar] que cada uno de por sí es el mejor, y, leídas las primeras dicciones dél azia abaxo, forma una redondilla a favor del segundo, y leidas las segundas dicciones para arriba, deshazen la redondilla a favor del primero (hase de leer, para que haga perfectas oraciones, con la advertencia de [que] adonde huviere estrellita, haze asterisco o pausa, y que allí se acaba una oración”), hazaña sobre la cual ha llamado la atención en su prólogo: “...y principalmente el soneto a los dos libros suyos, en que encontré tales espinas, que no me atreviera oy a empeñarme en hazer otro del arte", o sea otro de tamaño artificio. (La fuente de estos datos es la malhumorada relación del contenido de la Rhytmica de Álvarez de Velasco que hace Menéndez Pelayo en su Historia de la poesía hispano-americana, ed. cit., t. 1, pp. 426-430, nota) .

$141 \mathrm{Y}$ para esa tercer parte tenía papeles inéditos de Sor Juana tan importantes como la "Respuesta a Sor Philotea de la Cruz". Bien es verdad oue, oor razones no difíciles de imaginar, la portada se imprimió con el orden invertido: Fama y obras pósthumas del Fénix de México..., etc. (Me valgo de la ed. de Madrid, 1714. La cita, p. 81).

142 Véanse los datos de Palau, s.t. "Cruz", y los de A. M. P., SJ, t. 1, pp. 
lutamente excepcional. No era frecuente que se imprimieran ni siquiera segundas ediciones de poetas.

Se podría hacer un paralelo o contraste entre Góngora y Sor Juana, tomando al primero como culminación del siglo xvi y a la segunda como culminación del xvn, siglo más movido, más inquieto y complejo que el anterior (entre otras cosas porque, aparte de todo lo asimilado por él mismo, incluye todo lo asimilado antes por Góngora). Una diferencia notable es que Sor Juana no tuvo la descendencia que tuvo Góngora. Esto es claro en lo que se refiere al mínimo detalle cuya historia he estado siguiendo en el presente artículo. Después de Sor Juana, y aun descontando lo mucho que debe habérseme escapado, salta a la vista el poco número de novedades que hay en cuanto a esquemas del romance. En los párrafos siguientes va a haber algún romance decasílabo, algún laberinto, pero va a haber sobre todo, tediosamente, romances de arte mayor y endechas endecasílabas (formas anteriores a Sor Juana). Los avatares barrocos del romance terminan prácticamente en Sor Juana. De ahí el título de mi artículo. El lector que sólo se interese en esa historia puede leer en diagonal todo el resto.

[\$ 128$]$ He mencionado supra, p. 429, nota 141, el volumen de Fama y obras pósthumas del Fénix de México, dézima Musa, poetisa americana Sor Juana Inés de la Cruz, publicado en 1700. Para mi actual intento, la cosecha que arroja este volumen es muy magra.

Hay, en primer lugar, un romance de arte mayor de Joseph de Cañizares, famoso más tarde, mozo de veinticuatro años a la sazón: "Lamentos del Parnaso en la muerte de la célebre y única poetisa la Madre Sor Juana Ynés de la Cruz". Cito sus dos primeras coplas (Fama..., ed. de 1714 , p. 37) para invitar al lector a descubrir en ellas un tono distinto del de los romances endecasílabos anteriores -un tono, por decir así, "pre-neoclásico":

¿Qué es esto, Urania celestial? ¿Qué es esto,

Calíope, Polymia, Erato, Euterpe?

¿Cómo todas seguís el grave, el triste

lamento funeral de Melpomene?

¿Qué es esto, Clío? La guerrera trompa

¿Cómo en ronca sordina se convierte?

Terpsícore, el albogue placentero

¿cuándo sonó tan lastimosamente?...

xxx-xxxi. "Los tres tomos -dice Menéndez Pelayo, op. cit., t. 1, p. 77, nota... se reimprimieron varias veces durante el siglo xvm, en Madrid, Barcelona, Zaragoza, Valencia y otras partes. Todas estas ediciones... eran vulgares en España... No he visto ediciones de México, pero las habrá seguramente, totales o parciales...", lo cual no es así; fueron las ediciones españolas las que aquí circularon. 
[\$ 129$]$ En las pp. 93-98 hay otro romance de arte mayor, muy largo, "En alabanza de la venerable madre Juana Ynés de la Cruz, autora deste libro". Su autor es aquel Marcial Benetasúa Gutmán a quien vimos en 1683 como estudiante en Nápoles $(\$ 61)$, y que ahora, seguramente cuarentón, se llama Marcial Beneta Sua (¿o será Benet Asúa?) Gudeman. Castorena elogia (p. 92) "lo limpio del lenguage" de este romance, su "transparencia". Es, en efecto, una buena muestra de esa poesía "prosaica" y no-gongorina de la cual las historias de la literatura han hecho representante a don Eugenio Gerardo Lobo.

[§ 130$]$ En las pp. 294-297 hay otro romance de once sílabas, llamado ahora romance heroyco. Su autor es el licenciado Lorenzo González de la Sancha, mexicano ${ }^{143}$. Se intitula "Elogio funeral en la muerte de la madre Juana Ynés de la Cruz", y en él se hace "alusión a un erudito romance que en elogio de la Poetisa escrivió el delicadíssimo ingenio de $\mathrm{D}$. Joseph Pérez de Montoro, y anda impresso en el tomo primero de las Obras de Sor Juana". Es una composición tan aceptable como la de Cañizares y la de Benetasúa, aunque menos emancipada que la de éstos de la retórica gongorina ("al ayre triste de su torpe canto...", "fresco el incendio, como claro el humo..." 144 .

[\$ 131 I] El bachiller y presbítero Joseph de Villena, "colegial real en el Colegio de Christo, en México", contribuye a la Fama de la monja (pp. 287-291) con unas endechas endecasylavas rebosantes de erudición grecolatina:

143 En su prólogo, pp. 84-85, anuncia Castorena que los inéditos de Sor Juana irán precedidos de versos de "ingenios de la Europa" y seguidos de los de "América Septentrional Mexicea y Meridional Peruana". Y explica, graciosamente: "Los de Madrid van al principio, los de México a lo último del libro: éstos, como en prenda tan suya, heredando de su conquistador ser Corteses, generosos ceden el favor de la primacia" (si bien "vnos y otros aumentan lo que la luz al espejo"). Más adelante, en su presentación del ramillete mexicano, Castorena dice (p. 272) que las poesías que lo integran proceden de "vn libro muy erudito, en rumboso estilo intitulado Exequias mythológicas, llantos piérides, coronación apolinea en la fama pósthuma de la singular Poetisa...", compilado por el licenciado González de la Sancha, y que él, Castorena, había llevado a Madrid con esperanzas de publicarlo integro.

144 A. M. P., $P N$, t. 3, pp. 146-150, publica una canción petrarquista de este González de la Sancha, pero ni allí ni en su presentación del poeta (pp. xlv-xlvi) menciona su romance heroico. Alude, en cambio, a su "Elegía fúnebre" publicada en el mismo volumen de Fama y obras pósthumas, pp. 307-316, calificándola justamente de "mediocre" (es una silva que incluye un largo trozo en romance octosílabo). Dice, por cierto, que Castorena alaba el "rumboso estilo" de las Exequias mythológicas, pero, en mi opinión, lo único que hace Castorena es notar lo pomposo del título discurrido por González de la Sancha. 
América, no llores

la muerte de tu Musa

Juana Inés; o permite

que suavizen mis ecos tu fortuna.

No dudo que fue golpe

de la Parca sañuda,

si se ha de llorar, digno

del llanto de Hipocrene y Aretusa...

[§ 132] Son también endechas endecasílabas las que dedican a la monja mexicana dos monjas portuguesas, Soror Mariana de Santo António y $\mathrm{D}^{\mathrm{a}}$ Simõa de Castilho. Se han publicado recientemente, en la Revista de Literatura de Madrid, 33 (1968), pp. 69-71 y 74-75.

[§ 133] Soror Francisca Xavier, portuguesa también, le dedica un romance de arte mayor, publicado ibid., pp. 72-74.

[\$ 134$]$ Ya me he referido (supra, p. 429, nota 140) a don Francisco Âlvarez de Velasco y Zorrilla, "gobernador y capitán general de la provincia de Neyba y La Plata y procurador general para esta real corte de Madrid por la ciudad de Santa Fe [de Bogotá], cabeça y corte del Nuevo Reyno de Granada", uno de los más fanáticos devotos de Sor Juana y, desde luego, el que dejó muestras más abundantes y más clamorosas de su devoción. En su Rhytmica sacra, moral y laudatoria ${ }^{145}$ hay un romance endecasylavo "A honra y gloria de la Beatíssima Trinidad y de la Inmaculada Virgen María", y

$1 \pm 5$ En la portada del "voluminoso tomo colecticio" examinado por Menéndez Pelayo en la Biblioteca Nacional de Madrid (Hist. de la poesia hisp. -amer., loe. cit.) se explica que las obras de que se compone fueron impresas "por distintos impressores en diferentes lugares y tiempos"; de ahí que su foliatura, como dice Menéndez Pelayo, sea "varia y confusa". La parte inicial se imprimió en Burgos en 1703. Las noticias que de este libro ofrece don Marcelino (más detalladas que en otros casos a causa de "su singular rareza y algunas curiosidades que contiene”) nos hacen ver que Álvarez de Velasco fue muy criticado por el gallinero literario peninsular a causa de su americanismo, hasta el punto de haber quedado "acomplejado", como ahora se dice. En el prólogo, justifica una "disgressión" sobre sus hazañas versificatorias ("me atreví a fábricas nuevas de metros y a otras varias inventivas nunca de mí vistas, ni aprendidas de otros, cautivándome a violencias no fáciles de emprender sin este motivo, y sin los molestos ocios de mi melancólico retiro...", etc.) diciéndole al lector: ". porque si por baxos despreciares los versos deste libro, les hagas algún agasajo por el mérito que tienen en su trabajo, como también lo reconocerás en otras nuevas inventivas de varios metros y composiciones que tengo en otras obras cómicas, que por algunos motivos las retiro por ahora de la imprenta". Y, en efecto, Menéndez Pelayo lo califica de "innovador en la métrica". (Sobre la "novedad" como mérito, a falta de otro, véase Maluenda, supra, \$10). 
otro romance endecasílavo de esdrújulos dedicado "a la señora Soror Juana de la Cruz".

[\$ 135] Hay también, dedicadas “a la misma señora” (Sor Juana), unas endechas endecasílabas que Menéndez Pelayo se ve precisado a elogiar por su "soltura y gracejo de buena ley, familiar y culto a un tiempo". No sólo es muy amable su imaginación ("Si oyes un ruidito en tu celda, entre tus papeles, es un duende, y ese duende soy yo"), sino que pinta muy gráficamente lo que es la curiosidad de un lector por "lo que estará haciendo ahora" un poeta admirado:

Paisanita querida

(no te piques ni alteres,

que también son paisanos

los ángeles divinos y los duendes):

Yo soy este que - trasgo,

amante inquieto- siempre

en tu celda, invisible,

haciendo ruido estoy con tus papeles...

[\$ 136] Una de las "inventivas" de que más ufano se muestra Álvarez de Velasco es un "romance eneámetro [en] que empieçan y acaban todos los pies con esdrújulos". Está dedicado “A los Dolores de la Virgen" ${ }^{146}$, pero desde el punto de vista métrico es más bien un nuevo homenaje a la monja poetisa. "Entre las primorosas obras de Sor Juana - nos dice- hay un elegante eneámetro de vna pintura a la Señora Virreyna" (o sea el romance comentado en el $\S 97$ ); pero Sor Juana "gustó" de hacer su eneámetro ${ }^{14 \tau}$ con $u n$ esdrújulo al comienzo de cada pie, y entonces él, reconociendo que el suyo "estaría más sonoro (aunque también más trabajoso)" si metiera dos esdrújulos en cada pie, uno al comienzo y otro al final, se ha propuesto superarla. Las dificultades han sido tremendas, porque,

146 Antes de este romance hay unas "Elegías decámetras a los Dolores de la Virgen Santíssima, ajustadas de distintos centones de Virgilio". Menéndez Pelayo dice que son cuartetos endecasílabos (no aclara si de romance) y que "a cada uno de ellos siguen los versos de Virgilio de donde están sacados los pensamientos".

147 Si, eneámetro. Aquí, como en las elegias decámetras mencionadas en la nota anterior, se reconoce la terminologia revolucionaria de Caramuel (cf. supra, p. 354). Menéndez Pelayo observa que Álvarez de Velasco está versado "no sólo en los primores de Rengifo, sino en los de la Rythmica del Obispo Caramuel, a quien más de una vez cita" (y recuérdese que su libro se llama Rhytmica sacra..., etc.). El dato es curioso. No sé de ningún otro poeta hispano en quien haya ejercido alguna influencia aquel "loco genial" que fue Caramuel. Por cierto, el bogotano se muestra ecléctico: al "romance endecasilabo" y a las "endechas endecasílabas" les deja su nombre normal. 
"presa y engrillada la expresión de los conceptos entre las guardas de los dos proparoxítonos o esdrújulos, apenas puede salir a explicarse por la estrecha puerta del medio" (¡admirable imagen, por cierto!). Si con todo esto hay expresión en el poema, es algo que el poeta bogotano deja que el lector decida. Menéndez Pelayo no hace referencia más que a su "extravagante estructura" 148; Méndez Plancarte (SJ, t. 1, p. 458) lo llama "precioso romance". Comienza así:

¡Ánimo, corazón! Y si tímido, prófugo, en tus lágrimas pávidas náufrago, hoy presumes atónito únicas tus congojas fantásticas, vuélvete, pues te miras por mísero huérfano, a María con fe cándida...: mírala traspasada en más lúgubres íntimas del Amor flechas trágicas...

Lo que no se puede negar es que Álvarez de Velasco está diciendo $\operatorname{cosas}^{149}$.

[\$ 137$]$ Después de ponderar lo arduo del romance eneámetro, Alvarez de Velasco continúa: "No [son] de menos violencia y dificultad para mí los laberintos de las cruzes que yo compuse en su obsequio" (o sea en obsequio de Sor Juana, autora también de un "laberinto", § 100). Hay en él cierto juego con la palabra Inés y con su anagrama, Nise, que no se alcanza a entender por la inscripción del poema, que es lo único que copia Menéndez Pelayo: "Al último nombre de Soror Inés Juana [sic!] de la Cruz, laberinto en que se lee la copla endecasílaba que se verá por los intermedios de la cruz; y en el medio de ella, el nombre de Inés y Nise, que se lee por todas partes". No es el único. Hay otro "laberinto [en] que se lee por muchas partes el nombre de Santa Bárbara".

[\$ 138] Poética festiva celebridad a los años y nombre de Carlos II, rey de las Españas, executada en la Casa de Deputación..., Valencia, 1691, p. 51: romance heroyco (de once sílabas).

[\$ 139] Poesias escritas por algunos ingenios valencianos al acierto con que toreó, en las fiestas que se hizieron en Valencia a la cano-

148 Remite, además, a lo que antes ha dicho del "capricho métrico" que él cree invento (desafortunado) de Sor Juana. Cf. supra, p. 412, nota 117.

149 Menos mal que no conoció los versos también "eneámetros" de Pérez de Montoro (cuyas obras no estaban aún impresas), porque en ellos no queda siquiera "la estrecha puerta del medio", ocupada como está por un tercer esdrújulo-gendarme (supra, § 81). Si el bogotano hubiera querido superar esta proeza, de seguro se habría vuelto loco. 
nización de San Pasqual Baylón el dia 28 de mayo 1621, el ilustrissimo señor D. Guillén de Rocafull y Rocaberti..., [Valencia], 1691: pliego suelto que contiene un romance común y corriente y tres intitulados romance heroyco (de once sílabas), por don Pedro Mayor, Isidro Costa de Alón y Segura y don Francisco Figuerola, respectivamente.

[\$ 140] Fray Joseph de Jesús, Cielos de fiesta, musas de pascua en fiestas reales que a S. Pascual [Baylón] coronan sus más finos y cordialissimos devolos..., Valencia, 1692, pp. 165, 173 y 174: tres composiciones llamadas romance heroico (de once sílabas).

[\$ 141] Justa literaria, certamen poético o sagrado influxo... en la canonización de... San Juan de Dios... La describe don Antonio de Sarabia, secretario que fue de dicho certamen, Madrid, 1692: dos romances de once sílabas intitulados romance de arte mayor, pp. 68 y 78 .

[\$ 142] Ibid., pp. 70, 73, 75, 80, 83 y 85: otros seis, del mismo metro, intitulados romance heroico.

[\$ 143] En el desordenadísimo tomo 42 de la Biblioteca de Autores Españoles publica Adolfo de Castro (p. 448) un romance heroico "A San Juan de Dios", de Fernando Valenzuela. Comienza así:

Si empresa es problemática el asunto que hoy del Pirene la eminencia ocupa, cuya expresión empeño indisoluble fuera a Tagete, oráculo de Etruria, muy sutil equilibrio es mi desvelo para que en él, intrépido, presuma dos héroes balancear que solamente la inmensa ciencia ingénita gradúa...

Los dos héroes que de manera tan temeraria presume balancear el poeta en este romance son Santiago Apóstol y San Juan de Dios. Me detengo en él para que se vea una muestra del nuevo lenguaje que se está implantando ("empresa problemática", etc.), y también para observar que según BAEHR, p. 223, "representa un temprano testimonio, quizá el más antiguo, del romance heroico..." (San Juan de Dios fue canonizado por Alejandro VIII, papa de 1689 a 1691: para esas fechas ya se habian escrito montones de ellos) ${ }^{150}$.

150 T. N. T., p. 241, había sido más cauto: "A la segunda mitad del siglo Xvir corresponden las primeras manifestaciones del romance endecasílabo...: se encuentra en una composición de Fernando Valenzuela... y en va- 
[\$ 144] Del mismo Fernando Valenzuela publica Castro (ibid., pp. 447-448) unas "endechas [de 7-7-7-11] que compuso en el puerto de Acapulco, donde se embarcó para pasar a Manila, lugar de su destierro".

[ $\$ 145]$ La composición con que fray Joseph Antonio de Hebrera y Esmir, un eclesiástico de muchas polendas en tiempos de Carlos II, elogia a Antonio de Solís en los preliminares de la edición póstuma de sus Poesias, publicada en 1692 (supra, $\$ 57$ ), se intitula romance. Es de once sílabas.

¡§ 146] En los anónimos Villancicos que se cantaron en la catedral de Puebla en honor de San Antonio de Padua (Puebla, 1693) encontró A. M. P., $P N$, t. 3, p. 126, unas "coplas en endechas" de 77-7-4 (combinación "rara", según observa él mismo con toda razón) :

Derretido en amores, como portugués fino, así se goza Antonio con Dios Niño:

"Hechizo de mi alma, que con tan dulce hechizo de Vos sólo se acuerda mi cariño..."

$\lceil\S 147]$ Los modernos no solemos leer a Anicio Manlio Severino Boecio, que fue para la cultura y Weltanschauung hispánicas de ctros tiempos un alimento tan sustancioso y tan duradero. Quizá ningún autor latino fue traducido tantas veces al español. Lo más curioso es que cuatro de las traducciones de la Consolación de la Filosofia se hayan hecho en las postrimerías del siglo xvn; cuatro,

rías poesía de... Sor Juana Inés de la Cruz". En la misma p. 223 hace BaEHR otras peregrinas afirmaciones a propósito del romance de once sílabas: dice que es "un testimonio notable de la vitalidad del romance, que puede renovarse aun en el declive que se inicia en el romance octosílabo-icomo si en el siglo xvn, o aun en el xvm, hubiera habido tal "declive"! -, y que "atestigua también la definitiva asimilación del endecasílabo introducido de Italia en el Renacimiento" - ¡como si hasta entonces la "asimilación" hubiera sido tentativa o provisional! - Ignoro las fechas de nacimiento y muerte de Valenzuela. Lo único que se saca en limpio de la noticia de Adolfo de Castro, loc. cit., pp. c-ciii, es que fue un personaje político (y "problemático") de la época de Carlos II. - A lo que parece, en México andábamos muy atrasados de noticias por esas fechas: es de 1700 "el Certamen por la canonización de S. Juan de Dios..., que describió el Pbro. Br. D. Juan Antonio Ramírez Santibáñez en su Culto festivo, México, 1702"' (A. M. P., PN, t. 3, p. xlv). Cf. otro caso infra, $\$ 166$. 
a pesar de que la de Esteban Manuel de Villegas era no sólo bastante reciente, sino de muy grata lectura. La situación del imperio español, bajo un monarca que física y espiritualmente era la negación misma de la vitalidad, muy probablemente tendrá que ver con esa floración de traducciones, tan a destiempo. Se tiene casi la impresión de que el único consuelo que les quedaba a los españoles era el de la remota, nebulosa y abstracta "Filosofía" de Boecio.

Dos de esas traducciones me interesan aquí. De ellas se ocupa Menéndez Pelayo en su Bibliografia hispano-latina clásica, Madrid, 1902, pp. 266-271 (reedición de Santander, 1950, t. 1, pp. 328-334). La de Antonio Pérez Ramírez comprende sólo el libro I del De consolatione, "abrumado - dice Menéndez Pelayo- por un enorme e impertinente comentario" (Armas contra la Fortuna..., Valladolid, 1698). La de Agustín López de Reta es total, pero no se publicó hasta 1805, en Madrid (Los cinco libros del consuelo de la Filosofia...). Como queda dicho a propósito de Villegas (\$ 27), uno de los estímulos de los traductores de Boecio era la oportunidad de lucimiento por el empleo de "variedad de metros". Desde el punto de vista del romance, sin embargo, la cosecha es bastante escasa.

Pérez Ramírez emplea el romance endecasilabo, tan aclimatado para entonces como el heptasílabo, que también emplea.

[ $\$ 148]$ López de Reta, cuya traducción “es, para mi gusto, la mejor que tenemos de Boecio, aunque por ventura sea la menos conocida y celebrada" (Menéndez Pelayo), "empleó todavía mayor variedad que Villegas en la versión de los metros". En cuanto al romance, se sirve de la combinación de 8-8-8-10 que ya vimos en la antología de Alfay $(\$ 20)$ :

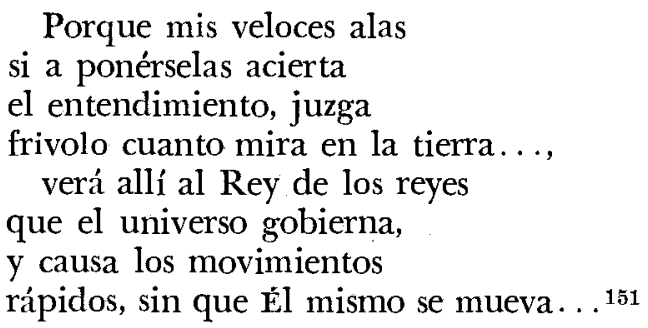

[ $\$ 149]$ Más conocida nos es la combinación de 10-12-10-12, la del célebre "Mari-Zápalos" de Camargo (\$ 12), que a estas alturas ha tenido ya tantos cultivadores. La versión del metro 11 del libro III comienza así:

151 La cita (metro 1 del libro IV) no procede de Menéndez Pelayo, sino de A. M. P., $S J$, t. 1, p. 457, quien la toma de una reimpresión mexicana (Guanajuato, 1852). 
Quien con sabio discurso investiga

lo más verdadero en cualquiera opinión,

y no quiere engañarse con tantas

como ha introducido en el mundo el error...

(Suele leerse en los manuales que tal o cual metro "sirve" para tal o cual asunto. ¿Hay cosas más distintas que estos versos y los de Camargo? Y sin embargo la medida es la misma, y los acentos van cuidadosamente colocados en los mismos lugares).

[\$ 150] A juzgar por su título, la visión boeciana de la vida no está lejos del Despertador del alma al sueño de la vida publicado en Lisboa en 1695 como obra de un "Apolinario de Almada" probablemente inexistente, pues se trata (según el catálogo de la Hispanic Society of America) de un producto de la pluma de $\mathrm{D}^{\mathrm{a}}$ Joanna Josepha de Meneses, tercera condesa de Ericeira. No leí el libro, pero en los preliminares me topé con un elogio en romance endecasílabo. (iTriste suerte, por cierto, la de estos libros escritos en castellano por portugueses! Nadie les hace caso).

[\$ 151$]$ En el Ramillete poético de las discretas flores del amenissimo, delicado numen del doctor Joseph Tafalla Negrete, Zaragoça, 1706 , p. 14, se llama romance a secas uno de once sílabas ${ }^{152}$.

[\$ 152] En Francisco Antonio de Bances Candamo ( $\uparrow$ 1704), Obras lyricas que saca a luz D. Julián del Rio Marin, Madrid, 1720, hay a partir de la p. 36 varias composiciones llamadas romance heroyco (cuartetas de once sílabas). En una de ellas el poeta "llora la gloriosa muerte del excelentíssimo señor don Manuel Diego López de Zúñiga, que sucedió a 16 de julio, de vn mosquetaço que recibió en vn assalto de Buda, capital de Vngría, año de 1686":

¿Qué Monstruo alado con siniestro buelo

el viento inunda pereçoso y grave,

tegiéndole las alas vagarosas

nocturnas plumas de funestas aves?...

¿Es la Fama? Sí...

[§ 153] Bances Candamo cultivó asimismo las hendechas hendecasílabas (cuartetas de 7-7-7-11) : véase la edición de sus Obras lyricas por F. Gutiérrez, Barcelona, 1949, pp. 291-298.

$152 \mathrm{El}$ Ramillete es póstumo, pero en ningún lugar he encontrado las fechas de nacimiento y muerte del autor. Tafalla Negrete es uno de tantos escritores oscurisimos. Su Descripción de las fiestas... a la ... beatificación solemne de San Pedro Arbués es de 1664. Quizá esta papeleta debiera colocarse antes. 
[\$ 154] La Descripción de las fiestas de cañas y toros con que la muy noble y muy leal ciudad de Sevilla celebró la llegada del Exc. Señor Almirante de Castilla... por Antonio Francisco de Flores, [Sevilla, 1707], está hecha en cuartetas de romance de once sílabas. Aunque la dedicatoria habla de "assumpto tan heroyco" (itantos Narcisos sevillanos hechos Martes, matando toros después de hacerlos sufrir de mil maneras!), en la portada se dice romance a secas.

[\$ 155] El afecto de Un Forastero en ocasión de aver visto parte de las fiestas con que la muy noble y muy más leal ciudad de Burgos, cabeça de Castilla y cámara de Su Magestad, celebró el nacimiento de nuestro gran principe Luis Primero, [Burgos, 1707], está hecho en romance heroyco (cuartetas de once) - cosa que ya hubiera podido imaginarse al leer ese "gran príncipe" aplicado a la criatura recién nacida.

[§ 156] En la Hispanic Society of America hojeé rápidamente el manuscrito de la limeña Flor de Academias, o sea el volumen de actas de las sesiones de una notable tertulia de literatos que se reunía bajo la presidencia del ilustrado virrey Castell-dos-Rius con tal frecuencia y ardor, que aquello no duró más de unos pocos meses, de fines de 1709 a comienzos de 1710. (Uno de sus miembros fue ese Conde de la Granja a quien mencioné supra, p. 427, al final de la nota 137). En la sesión del 19 de diciembre de 1709 uno de los contertulios leyó un romance heroyco (de once sílabas) en loor de Felipe $\mathrm{V}$.

[\$ 157] Y cinco días después, otro contertulio leyó un romance de arte mayor (también de once sílabas, claro).

[\$ 158] He tenido la rara oportunidad de asomarme a las poesías de Gabriel Álvarez de Toledo Pellicer y Tobar (1662-1714) por partida doble: en el manuscrito núm. CV de la Hispanic Society of America (que lleva la fecha "1719") y en el volumen impreso: Obras pósthumas poéticas, con la Burromaquia. Sácalas a luz el doctor don Diego Torres Villarroel, Madrid, $1744^{153}$. Contienen buen número de romances endecasylabos.

[§ 159] Pero en el índice del volumen impreso, esos mismos romances se suelen apellidar heroycos.

153 Es notable la frecuencia de las ediciones póstumas en estos tiempos. Se diría que hacía falta un entusiasmo muy sostenido por parte de los lectores. Lo que admiraba Torres Villarroel, ese entusiasta curioso y desconcertante, era evidentemente la Burromaquia, una obra a la que hoy es dificilísimo hincarle el diente. 
[§ 160] Una de las poesías más notables de estas Obras pósthumas es la dirigida "A mi pensamiento", en endechas de 7-7-7-11. (Puede verse en el t. 42 de la $B A E$, p. 199).

[§ 161] Al final del Cathólico triumpho de Felipe $V$ contra las armas imperiales. .. por José Luis de Velasco Arellano, México, 1712, hay (fols. 23-26) una elegía "Por la muerte del señor Delfín" (o sea \&l padre de Felipe V), en romance de once sílabas. (Poema filosófico, con la advertencia de cajón a los poderosos: "Porque nacen iguales al sepulcro / como el pastor humilde entre sus mieses...", versos citados por A. M. P., PN, t. 3, p. 169).

[§ 162] El segundo de los Villancicos de Pedro Muñoz de Castro para la fiesta de la Asunción de la Virgen en la catedral de México, 1717 (A. M. P., $P N$, t. 3, pp. 201-202) es un romance en cuartetas de 7-5-7-5:

Muerte de mala muerte, muerte alevosa, diocleciana enemiga, cruel y traidora;

ya que de Diocleciano

eres la copia,

bien puedes ocuparte

en cazar moscas...

[\$ 163] El séptimo de esos mismos Villancicos es un "romance irregular, entre el arte mayor y la muñeira” (A. M. P., ibid., p. 203) :

... Suba al empíreo la Madre del Verbo,

suba a los cielos gloriosa, que allá

-repostera del mundo- os previene

en su celeste palacio lugar...

Que os adoren los hombres es justo;

todos os juren su reina, y por tal, pecho por tierra, rendidos vasallos

reina os aclamen por tierra y por mar...

Se comprende la indecisión de Méndez Plancarte. Yo la comparto. No es, desde luego, el metro del "Mari-Zápalos". Tampoco un romance endecasílabo. Pero, considerando que seis de los ocho versos de la cita son "de arte mayor", asimilables al dodecasílabo (véase un caso más claro infra, $\$ 172$ ), yo diría que esta muestra puede llamarse romance dodecasilabo.

[§ 164] En la Venezuela colonial, dice Menéndez Pelayo (Hist. de la poesia hisp.-amer., ed. cit., t. 2, p. 349), no faltaron "versificado- 
res gongorinos, de lo más enfático y perverso dentro de su género. Al frente de la Historia de la conquista y población de la provincia de Venczucla, de D. José de Oviedo y Baños (Madrid, 1723), escribió el licenciado D. Alonso de Escobar, canónigo de la catedral de Caracas..., un romanzón endecasílabo congratulando a la ciudad de Caracas en estos revesados términos:

Coronado León, de cuyos rizos altivas crenchas visten el copete, gallarda novedad que su nobleza generosa guardó para sus sienes..."

[\$ 165$]$ Entra ahora en el Catálogo uno de los escritores más ilustres del siglo xvin español: el padre Feijoo, de quien a veces se olvida que también escribió versos. Feijoo, dice D. Gamallo Fierros, empleó varias "fórmulas métricas favorecedoras de su tendencia a abrirse paso hacia el futuro romántico", una de ellas la endecha real (coplas de 7-7-7-11) 154. Los versos de la "Batalla de un amante contra su propia pasión":

... Ay obstinada pena!

;Ay infeliz constancia!

iAy fuego inextinguible!

iAy dolor que atormentas y no matas!...

le hacen decir a Gamallo que casi parecen del Don Alvaro del Duque de Rivas ("iOh vosotras, estrellas, / de mi tragedia causa! / O robadme la vida, / o bien volvedme la quietud robada..."). Puede ser. A mí me suenan más bien a imitación de la poesía del pasado, la de fray Luis por ejemplo. Y en cuanto al lamento de Feijoo por la muerte de Luis I (1724), parece inspirado en las endechas de Solís a la conversión de San Francisco de Borja (supra, § 57), elogiadas expresamente por el benedictino:

Detente, pasajero,

y desengaños logra.

154 D. Gamallo y Fierros, "La poesía de Feijoo", $B B M P, 40$ (1964), 117 165, en particular pp. 126-134, sobre las endechas reales y sus "precursores". Me parece muy curiosa la visión de este crítico: un Feijoo que, consciente de su "tendencia" a abrirse paso hacia los tiempos de Rivas y Bécquer, decide adoptar los esquemas métricos más conducentes iy cae en uno que venía usándose por lo menos desde hacía ochenta años! De los "precursores", Gamallo mismo cita a Trillo, Solis, Valenzuela, Sor Juana, Álvarez de Toledo y Bances Candamo (supra, $\$ \S 14-15,57,144,102-103,160$ y 153). Cita también a Bermúdez, cuyas estrofas no son endechas (cf. supra, p. 380, nota 79), y añade las Fiestas minervales de Santiago de Compostela, 1697, que no conozco. 
Feliz tú, si se imprimen

en ti los caracteres de esta losa...

[\$ 166] Los "desengaños" evocados por Feijoo eran en verdad ejemplares. El príncipe Luis, hijo de Felipe V, había muerto antes de cumplir los diecisiete años. En 1722, cuando tenía catorce y algunos meses, se había casado con una prima suya, francesa, de doce. Para celebrar esas bodas, en las cuales se veía un augurio de alianza perpetua entre Francia y España, se organizó en México, en la ciudad minera de Zacatecas, un certamen poético que mereció los honores de la imprenta: Estatua de la Paz antiguamente colocada en el Monte Palatino por Tito y Vespasiano cónsules, y aora nuevamente trasladada a los reynos de España y Francia por la cathólica magestad de... Phelipe V. Cuya alegórica traslación celebraron los ingenios zacatecanos..., México, 1727. Claro que en 1727 hacía ya tres años que el cadáver de Luis I se pudría en la tumba ${ }^{15 \pi}$. Pero se pensó, seguramente, que esta circunstancia no tenía por qué impedir la publicación del certamen. Hubiera sido una lástima. Los vates zacatecanos se habían lucido. El impreso contiene "4 romances endecasílabos (por el mercedario fray Juan de Argola, don Juan Ignacio de Larrañaga y otros) ... donde los 24 versos de cada cual forman 3 columnas de acrósticos, según que se lean como de 11 , o como de 8, o como de 6 sílabas" (noticia de A. M. P., SJ, t. 1, p. 465, que por desgracia no cita más que un solo verso: "Vivientes - Tiorbas - Reverentes demos"). Se trata, pues, de romances-laberintos como los que ya se han visto ( $\$ \$ 46,88$ y 100), pero con la adición de otra gala: el acróstico.

[\$ 167] Dan ganas de pensar si Felipe V no habrá planeado el acto que dio lugar al siguiente impreso: Sagradas flores del Parnasso, consonancias métricas de la bien templada lyra de Apolo, que a la reverente cathólica acción de aver ido acompañando Sus Magestades al SSmo. Sacramento que iba a darse por viático a vna enferma, cantaron los mejores Cisnes de España, Madrid, 1723. En todo caso, en la p. 164 hay un romance heroyco (de once sílabas).

155 Cf. el caso parecido de esta relación limeña: Elisio peruano: Solemni. dades heroicas y festivas demostraciones de júbilos que se han logrado en la muy noble y muy leal Ciudad de los Reyes, Lima, en la aclamación de $\mathcal{D}$. Luis Primero, Lima, 1725. "Tuvieron estas fiestas - dice Menéndez Pelayo, op. cit., t. 2, p. 142, nota- la rara condición de ser póstumas, puesto que Luis Primero había fallecido en 31 de agosto de 1724, y todavía en el Callao [sic] le estaban festejando a principios de febrero de 1725". (Pero en el mismo año de 1725 se publicaba en Lima una Parentación real, sentimiento público, luctuosa pompa, fúnebre solemnidad en las reales exequias de... D. Luis I). 
[\$ 168] Eugenio Gerardo Lobo (1679-1750) tradujo en cuartetas asonantadas de once sílabas la Heroida VII de Ovidio (Dido a Eneas). En sus Obras poéticas, edición de Ibarra, Madrid, 1758, esta traducción está en el t. 2, pp. 168-183.

[\$ 169] En el mismo metro está escrito su poema "A las suntuosas columnas del convento de la Cartuja de Roma", que puede verse en $B A E$, t. 61, p. 3. Con "neoclásica" sencillez, el poema se llama sólo endecasílabo ${ }^{156}$.

[\$ 170$]$ A. M. P. cita (SJ, t. 2, p. xxix) unos Villancicos del mismo Eugenio Gerardo Lobo a la profesión de una monja, en las conocidísimas coplas de romance de 7-7-7-11:

$$
\begin{aligned}
& \text {...El uno para el otro } \\
& \text { seremos, en un lazo, } \\
& \text { hasta que expire el día } \\
& \text { y se acerquen las sombras del espanto... }
\end{aligned}
$$

[§ 171] Fray Juan de la Anunciación, poeta mexicano que escribió en el primer tercio del siglo xvirI, es uno de los últimos en quienes he encontrado esquemas distintos de los habituales de 11-11-11II y de 7-7-7-11, que dan la impresión de ser los únicos que, después de la proliferación de años anteriores, quedan aceptados y consagrados, sin contar, por supuesto, los ya existentes en tiempo de Góngora. (Como dice P. H. U., p. 209, "entre 1725 y 1750, con la aparición del clasicismo académico, toda irregularidad en la versificación queda desterrada de la poesía culta"). A semejanza de Pedro Muñoz de Castro ( $\$ 162$ ), fray Juan de la Anunciación ${ }^{157}$ cultiva el romance en cuartetas de 7-5-7-5. Véanse sus seguidillas "Al Amor":

156 Observa A. M. P., $S J$, t. 2, p. xxix, que - "signo del nuevo tiempo"Lobo introduce designaciones como "recitado", "aria", "minué" y "cantada". Puede también observarse que el barroco título de la primera edición de sus obras, Selva de las Musas, que en elegante construcción poética prorrumpe la facunda de D. Eugenio Gerardo Lobo, Cádiz, 1717, se abandona a partir de la segunda edición (Cádiz, ca. 1724) en favor del sencillo y severo de Obras poéticas. Pero en esto de los títulos, como en tantas otras cosas, la transición es lenta. No se acaba de la noche a la mañana la tradición de los rótulos rumbosos, en España (Sagradas flores..., \$ 167) y en la América española (Estatua de la Paz..., Elisio peruano..., \$ 166).

157 Toda mi información sobre él procede de A. M. P., $P N$, t. 3, pp. lxiilxiii y 211-220, donde se da noticia de su manuscrito Cuaderno de varios versos (Biblioteca Nacional de México) y se exalta "su instinto y su ímpetu de rubeniano innovador de la rítmica". 
Una cosa, Cupido, quiero rogarte, por que excuses contiendas, riñas ni lances:

que no quieras conmigo

solo igualarte...,

que eres muy rapacillo

y yo muy grande...

[§ 172] A semejanza también de Muñoz de Castro (\$ 163), pero con más consistencia que él, fray Juan de la Anunciación cultivó los "endecasílabos dactilicos" de $\mathbf{5}+6$, siempre con cesura, de los cuales (aunque refiriéndose al siglo xv) dice T. N. T., p. 96: "Son... versos que en virtud de la equivalencia de sus primeros hemistiquios como verdaderos pentasílabos o como hexasílabos sin anacrusis, se pueden adaptar lo mismo a la medida simple y período único del endecasílabo que al compás binario y compuesto del dodecasílabo" ${ }^{158}$. Sin mucha violencia, pues, podemos hablar de romance dodecasílabo ante versos como éstos, "A la profesión de dos religiosas" de la orden de Santa Clara:

En el estrado de rosas fragante del más ameno de Clara jardín, hoy se entretejen dos tiernos pimpollos que hacen sus brillos más claros lucir...

Como del prado carbunclos con alma, eran antorchas del verde zafir...

El nombre que el poeta da a esta forma es minué. El nombre y el metro ya existían, pero se trataba sólo, al parecer, de cuartetas aisladas ${ }^{159}$. La novedad de composiciones como la citada consiste en que emplean el endecasílabo no italiano, sino el de gaita gallega, "con simetría y frecuencia nada común (aun mucho después y en España)", como dice A. M. P., loc. cit., p. lxii.

1šs T. N. T. cita los siguientes versos de Juan de Padilla, el Cartujano: "Éste, primero que su compañero, / hobo noticia de nuestro Mesias, / quando del hijo del buen Zacarias / fue denunciado por simple cordero", pero observa que la aparición de cuatro endecasilabos seguidos no es sistemática. $O$ sea, no se trata allí de un verso "autónomo".

159 Así el minué (¿̨de 1701?) con música de José Bassa que cita P. H. U. en la p. 174 ("Si de Amarilis los ojos disparan / flechas que hieren con dulce rigor..."), tomándolo del Teatro lírico español de Pedrell, donde hay "otros minués con metros semejantes". El fraile novohispano, dice A. M. P., $P N$, t. 3, p. 219, "dejó muchos minués", uno de ellos la traducción del himno Pange lingua. Sus citas fragmentarias no siempre dejan ver si se trata de romances. En los dos minués enteros que publica (uno de ellos muy bonito: "Ya las nocturnas fantásticas sombras...") no hay asonancia continua entre las coplas. Confieso que aquí falta mucha investigación. 
[ $§ 173]$ Fray Juan de la Anunciación fue en efecto un "gran innovador métrico". Recuerda un poco, a casi un siglo de distancia, a Jacinto Alonso de Maluenda. Igual que él, por ejemplo (cf. supra, p. 376, nota 70), hizo "décimas de hexasílabos", entre otros experimentos que menciona A. M. P. Uno de ellos es la letra a los Dolores de María, "tema predilecto del autor" - como de Álvarez de Velasco (supra, $\$ 136$ y nota 146) -, en "una linda estrofa" (A. M. P.) : octetas de romance de 8-8-6-6-6-6-6-6:

Hoy sale de madre, amante

de María el tierno mar,

en perlas creciente

que el puro cristal

de sus claros ojos

llega a desatar,

cuando a su Hijo muerto

ve en la cruz estar...

[\$ 174] Pedro José Bermúdez de la Torre y Solier, alguacil mayor de la Audiencia de Lima, publicó en esta ciudad, en 1730, una Aclamación afectuosa en aplauso de la heroica acción que executó el serenissimo señor Principe de Asturias matando a un loro en un bosque poco distante de la ciudad de Sevilla en defensa de la Princesa nuestra señora, el año passado de 1729, en romance endecasílabo. (Bermúdez de la Torre había sido miembro de la "academia" o tertulia del Marqués de Castell-dos-Rius, recordada supra, $\S 156$ ).

[\$ 175] Los hijos de Felipe $\mathrm{V}$ estaban a la sazón en el candelero, como lo muestra el Romance heroico al festivo obsequio con que la muy ilustre ciudad de Valencia celebró el arribo del serenissimo señor Infante don Carlos, [Valencia], 1731.

[ $\$ 176]$ Juan Joseph de Salazar y Hontiveros, Poesias varias en todo género de assumptos y metros, Madrid, [1732], p. 1: romance endecasílavo (en cuartetas de once sílabas).

[\$ 177] Ibid., p. 69: otro romance igual, llamado romance heroyco.

[\$ 178] Romance en endecasylabo donde se describe en verso las fiestas de toros que se celebraron en Cádiz con motivo de las victorias españolas en Orán, Cádiz, [1732].

[\$ 179] Ángel Peregrino, La mejor guirnalda de Apolo y corona del monte Parnaso, Madrid, 1749, p. 163: romance de arte mayor (de once sílabas). 
[\$ 180$]$ Ibid., p. 170: romance endecasylabo (cuartetas de 8-8-8-11).

[\$ 181] Isidoro Francisco Ortiz Gallardo, Noches alegres y divertidas en academias lyricas, morales y humanas, Salamanca, [1758], pp. 15 y 38: composiciones llamadas romance heroico (de once sílabas).

[\$ 182] Romance real en que doña Francisca Ossorio, entendida en el público por "la Musaraña [sic?] del Pindo", canta la bienvenida en nombre de España a Carlos III, Madrid, 1759 (apud M. Serrano y Sanz, Apuntes para una biblioteca de escritoras españolas, Madrid, 1903-1905, t. 2, núm. 277, p. 93) .

Romance real no era mal nombre para el de once sílabas (cf. supra, p. 381, nota 80), ya que el término romance endecasílabo, como acaba de verse $(\$ \S 176$ y 180$)$, y como se verá $(\S 183)$, seguía siendo equívoco.

[§ 183] Nicolás Fernández de Moratín, El poeta, Madrid, 1764, p. 57: romance endecasylavo (cuartetas de 7-7-7-11).

[\$ 184$]$ Ibid., p. 85: romance heroyco (cuartetas de 11-11-11-11).

[§ 185] Villancicos anónimos de la Natividad de la Virgen, Puebla de los Ángeles, 1764: romance en cuartetas de 7-5-7-5 (A. M. P., SJ, t. 2, p. xlv) :

Coronados de mirtos, jazmín y grana, locos andan los criados de Joaquín y Ana; todos de regocijo brincan y saltan, que parece la gloria toda la casa...

[\$ 186] En honor a las academias que... D. Joseph y $D^{a}$ Cayetana La Cerda y Cernesio, primogénitos de los... Condes de Parcent, celebraron los dias 16 y 18 de mayo de 1765, por un Apasionado de las Letras, Valencia, 1765. Curiosa relación, escrita en romance heroyco (cuartetas endecasilábicas).

[\$ 187] Casimiro Gómez Ortega, Tentamen poeticum en loor de Carlos III, Matriti, 1769. El texto latino va acompañado de su traducción en romance de once sílabas (en la edición original, Bononiae, 1759, estaba sólo el texto latino). Tramposamente, el huma- 
nista evita la populachera palabra "romance" y deja sólo la prestigiosa y clásica: Endecasylabo.

[\$ 188] Academia que se celebró en Palacio... en 1770, bajo la presidencia de don Antonio de Zamora, ms. IV de la Hispanic Society of America, fol. 13: romanze heroico (de once sílabas).

[\$ 189$]$ Vicente García de la Huerta tiene, en sus Obras poéticas, Madrid, 1778, varias composiciones en romance de once, llamadas simplemente endecasílabos, por ejemplo los "Endecasílabos recitados en la Real Academia de San Fernando". (Pueden verse cómodamente en $B A E$, t. 61, pp. 219-230, passim).

Todavía unos años después de la publicación de esas Obras poéticas, García de la Huerta, autor de una solemne Bibliotheca militar española (precedida de un discurso preliminar "sobre la utilidad del arte de la guerra'), publicará, en plaquette, unos Endecasilabos con motivo del bombardeo de Argel... por el general Sr. Antonio Barceló en agosto de 1783, Madrid, 1783.

[\$ 190] En algunos casos no desdeña García de la Huerta la designación tradicional de romance endecasílabo (v.gr. $B A E$, loe. cit., p. 226). En el mismo metro está escrita la "Égloga africana" intitulada Los bereberes.

[§ 191] En su traducción de la Heroida XII de Ovidio (Medea a Jasón), García de la Huerta avisa que "cada copla castellana [cada cuarteta de romance de once sílabas ${ }^{160}$ corresponde a un dístico latino del original". He aquí cómo traduce (Obras poéticas, ed. cit., t. 2, pp. 283-303) los versos 11-12 ("Cur mihi plus aequo flaui placuere capilli / et decor et linguae gratia ficta tuae?”) :

¡O, si jamás tu rubia cabellera, tu gentileza y afectada gracia en el hablar, tan desmedidamente hubiesen agradado a aquesta incauta!...

(Así como invité al lector, en el $\S 128$, a comparar el tono de Cañizares con el de sus predecesores, así ahora lo invito a comparar el tono de García de la Huerta con el de Cañizares).

160 La copla castellana, dice T. N. T., p. 525, es "una pareja de redondillas con cuatro rimas: abba-cddc". Pero, evidentemente, en tiempo de Garcia de la Huerta no era aún término técnico: él sólo hace la oposición idiomática latin/castellano. 
[§ 192] García de la Huerta cultivó asimismo las endechas reales (cuartetas de 7-7-7-11), por ejemplo en sus "Tristes expresiones de un desconsolado", BAE, loc. cit., pp. 225-226.

[§ 193] Tomás de Iriarte fue, en su época, el más grande innovador en materia de versificación ${ }^{161}$. En primer lugar, no he encontrado, antes de él, ningún caso de romance tetrasílabo, o "romancillo en versos de cuatro sílabas", como él lo llama en la lista de "Géneros de metros usados en estas Fábulas", que él mismo se preocupó de poner al fin de ellas. Aún guardo en la memoria versos de la fábula 47 ("La urraca y la mona"), que leía de niño:

A una mona

muy taimada

dijo un día

cierta urraca:

"Si vinieras

a mi casa,

¡cuántas cosas

te enseñara!..."

una hebilla,

dos medallas,

161 Es en verdad notable el descuido con que el último editor de las $F a^{-}$ bulas literarias, Alberto Navarro González (Madrid, 1953, t. 136 de Clás. cast.), trata un tema que en Iriarte justamente reviste tan gran importancia. De tan poco espacio (pp. 1-lii del prólogo) nadie va a esperar un análisis profundo, pero no sería mucho pedir siquiera un resumen claro de las innovaciones y los experimentos que muestran las Fábulas. No sólo no lo hay, sino que Navarro González parece más bien regatearle a Iriarte sus méritos de innovador. Califica, sí, de "alarde métrico" la serie de Fábulas, pero en seguida añade: "conviene observar que Irirarte no intenta una renovación métrica de nuestra poesía, sino tan sólo presentar la mayor cantidad posible de metros empleados en el Parnaso castellano", ;como si los pareados de siete sílabas, o los pareados de alejandrinos a la francesa, o las décimas de once sílabas, o los sonetos, tercetos y octavas de ocho (pese a los ralos antecedentes del Siglo de Oro registrados por T. N. T., pp. 246-247 y 252), o la mayor parte de los que registro en los párrafos siguientes, hubieran sido metros habituales en el Parnaso castellano! Peor aún: en las Fábulas, dice, "no hay intento de adaptar los metros clásicos, no hay versos mayores de 14 sílabas ni menores de cuatro, falta la rima al medio, no hay acrósticos ni juegos con las rimas... y lógicamente [sic!] tampoco hallamos empleo consciente del procedimiento poético de la correlación... [y también] se nota la falta de la copla manriqueña y tetrástofo [sic] monorrimo", -fatigosa (e incompletísima) enumeración de lo que no hay en Iriarte, de ninguna manera compensada por un estudio de lo que sí hay. Como contraste, véase el estudio de Dorothy Clotelle Clarke, "On Iriarte's versification", PMLA, 67 (1952), 411-419, cuya conclusión es que "todos los esquemas rítmicos experimentados por Iriarte florecieron vigorosamente" en la poesía romántica y aun en la modernista. 
la contera

de una espada...,

y aún me parece chistosa la manera como los minúsculos versos convienen tan perfectamente a lo fragmentario y deleznable de las posesiones de la urraca ( $y$ aún ignoro qué cosa es "la contera / de una espada"...).

[§ 194] En el $\S 11$ puse, con dudas, a Tirso de Molina como creador del romance eneasílabo. No hay duda posible en cuanto a Iriarte y su fábula 14 ("El manguito, el abanico y el quitasol"), que es, como él dice, un "romance en versos de nueve sílabas". Recuérdense, o reléanse, los versos de Tirso, "Borbollicos hacen las aguas...", y léanse en seguida los de Iriarte:

Si querer entender de todo

es ridícula presunción,

servir sólo para una cosa

suele ser falta no menor...

"Tú, manguito, en invierno sirves,

en verano vas a un rincón;

tú, abanico, eres mueble inútil

cuando el frío sigue al calor..."

[§ 195] E1 romance heroico aparece en dos de las fábulas: la 33 ("Para pasar el tiempo congregada / una tertulia de animales varios...") y la 35 ("Si se acuerda el lector de la tertulia / en que, a presencia de animales varios..."). Iriarte lo practica también para asuntos "elevados". Siguiendo el ejemplo de Gómez Ortega ( $\$ 187)$, traduce en ese metro su propio poema en hexámetros latinos "Al nacimiento del infante don Carlos Clemente", de 1771 (BAE, t. 63, pp. 38-39), y en él compone su poema "La paz y la guerra" (ibid., pp. 39-40), como también su monólogo o "unipersonal" Guzmán el Bueno.

[\$ 196] En endechas reales están escritas también dos fábulas: la 49 ("El jardinero y su amo") y la 75, póstuma ("El caracol y los galápagos") .

[§ 197] La fábula 34 ("El cuervo y el pavo") está escrita, dice Iriarte, en "versos de ocho sílabas y de seis, alternados, con dos asonantes":

Pues, como digo, es el caso

(y vaya de cuento)

que a volar se desafiaron

un pavo y un cuervo; 
al término señalado

cuál llegó primero,

considérelo quien de ambos

haya visto el vuelo...

El esquema de 8-6-8-6 en coplas de romance ya lo había empleado un siglo antes un poeta novohispano, probablemente Sor Juana (supra, $\$ 109$ ), pero la adición de una segunda asonancia (para los versos impares) es algo que a nadie, que yo sepa, se le había ocurrido ${ }^{162}$.

[ $\$ 198]$ Son parecidos a los anteriores los "versos de diez sílabas y de seis, alternados, con dos asonantes", en que está escrita la fábula 61 ("El sapo y el mochuelo") :

Escondido en el tronco de un árbol estaba un mochuelo, y pasando no lejos un sapo, le vio medio cuerpo...

Este esquema de romance de 10-6-10-6 lo hemos visto ya (aunque con la adición de tres versos más, 6-7-6) en una composición de Sor Juana ( $\$ 123$ ) que pudo servir de modelo a Iriarte ${ }^{163}$.

[§ 199] En cambio, el esquema 11-6-11-6 ("endecasílabos con quebrados de seis sílabas") no tiene, que yo sepa, precedente alguno. Se encuentra en la fábula 66 ("El ricote erudito") :

Hubo un rico en Madrid ( $y$ aun dicen que era más necio que rico) cuya casa magnífica adornaban muebles exquisitos... ${ }^{164}$

162 En la fábula 72, póstuma ("El canario y otros animales") hay otro juego aún más extraño. Son coplas hexasilábicas aconsonantadas: "De su jaula un día / se escapó un canario, / que fama tenía / por su canto vario..." (= Iriarte, nacido en Canarias, famoso por la variedad de sus metros); pero, además, los versos pares conservan la asonancia en á-o todo el tiempo. - El romance de consonantes (Iriarte, p. 117) ya había sido empleado por Maluenda (supra, final del $\S 10$ ).

163 El cual pudo verla no sólo en las obras de Sor Juana, sino también en las de León Marchante ( $\mathrm{y}$ en las de Pérez de Montoro pudo hallar un esquema parecido): cf. las notas del citado $\$ 123$.

164 Al adoptar la cuarteta de 11-7-11-7, Bécquer aportaría más tarde "una nueva modalidad de romance, más flexible y menos grave que la heroica", dice T. N. T., p. 343. (¿Cómo es posible que nadie la haya usado antes de Bécquer? ¿Si era tan fácil dar con ella!). 
[\$ 200] Félix María Samaniego, sucesivamente amigo y rival de Iriarte, dice en el prólogo de sus Fábulas morales: "Con la variedad de metros he procurado huir de aquel monotonismo que adormece los sentidos...", pero confiesa que predomina, con mucho, la silva (o, como él dice perifrásticamente, los "endecasílabos pareados con la alternativa de pies quebrados o de siete sílabas"). Practica también bastante el romance heptasílabo. Pero para los fines de mi Catálogo sólo cabe registrar las endechas reales que usa en la fábula 16 del libro I, en la 19 del II, en la 1 y la 24 del IV, en la 4 del $\mathrm{V}$ y en la 3 y la 9 del IX.

[\$ 201] Samaniego "escribió también la parodia del soliloquio Guzmán el Bueno (de T. de Iriarte), intercalando en el romance endecasílabo original algunos pasajes suvos de carácter grotesco" (Hurtado y González Palencia, Hist. de la lit. española, ed. cit., p. 732).

[§ 202] En 1778 la Real Academia Española convocó a los ingenios a un concurso poético: tema, Hernán Cortés; metro, octavas reales. En vista del éxito obtenido, el año siguiente hubo nueva convocatoria: tema, la conquista de Granada por los Reyes Católicos; metro, romance endecasílabo. Al mismo tiempo que la Academia rendía así honores a los grandes fastos del Imperio en vísperas del colapso ${ }^{165}$, reconocía la nobleza del romance de once sílabas, digno de codearse con las siempre prestigiosas octavas reales. Uno de los poetas concursantes firmó con el nombre de "Don Efrén de Lardnaz y Morante", anagrama de Leandro Fernández de Moratín, muchacho, a la sazón, de diecinueve años. Su poema, La toma de Granada por los Reyes Católicos, no obtuvo el primer premio, sino el accésit, pero se publicó de todos modos ese mismo año de 1779. (Puede verse en el t. 2 de la $B A E$, pp. 573-576).

[\$ 203] El poeta que derrotó a Moratín hijo en el concurso de 1779 era, jay! el mismo que en el del año anterior había derrotado a Moratín padre. Se llamaba Joseph María Vaca de Guzmán (1750$1810)$. Su romance endecasílabo Granada rendida se imprimió en 1779 en casa de Joaquín Ibarra (tal como se hizo con el de "Lardnaz") ${ }^{166}$. Varios otros de sus poemas, filosófico-morales como "El

165 Característicamente, el poema triunfador en el concurso de 1778, Las naves de Cortés destruidas (véase la nota siguiente), fue reeditado, con "Nota inicial" de un tal Delfín Escolá, por las Ediciones "Imperio", en' Roma, en 1939. (Eran los tiempos en que Franco, respaldado por Mussolini, lanzaba sus slogans de Imperio y de Hispanidad).

166 Veinte años después apareció una Colección de las obras de eloqüencia y de poesia premiadas por la Real Academia Española, Madrid (Viuda de Iba- 
triunfo sobre el oro", se llaman también romances endecasilabos. (BAE, t. 61, pp. 287-291 y 297-299; y allí también, pp. 283-287, el poema Granada rendida).

[\$ 204] A pesar de la consagración académica del término romance endecasilabo, Vaca de Guzmán no siempre lo usa: una composición escrita en romance de once sílabas se llama elegía (ibid., pp. 304-307).

[§ 205] Pero también se llama elegía un poema escrito en cuartetas de romance de 7-7-7-11, cuyo nombre era endechas endecasilabas (ibid., pp. 278-280). Y además, otro romance de 7-7-7-11 se llama oda (ibid., pp. 302-304) .

[§ 206] Finalmente, este mismo nombre, oda, se aplica a la poesía dedicada "A la muerte de don José Cadalso" (ibid., pp. 291-292), escrita en cuartetas de romance de 11-11-11-5, o sea en "estrofas sáficas", sí, pero de asonancia continua, idea que a nadie, que yo sepa, se le había ocurrido. Los endecasílabos son estrictamente "sáficos", con acentos en la $4^{\text {a }}$ y la $8^{\mathrm{a}}$ sílabas y cesura tras la $5^{\mathrm{a}}$, y el pentasílabo es siempre un "adónico":

Vuela al ocaso, busca otro hemisferio,

baje tu llama al piélago salobre,

délfico numen, y a tu luz suceda pálida noche.

Manto de estrellas el Olimpo vista, su gala oculten pájaros y flores, sombras y nieblas pavorosas cubran valles y montes...

[§ 207] Paulino Cabral de Vasconcellos, Poesias, Porto, 1787, al comienzo del tomo 2: dos romances hendecasyllabos.

rra), 1799, en cuya Segunda parte se reimprimen Las naves de Cortés destruidas (pp. 1.22), poema en 60 octavas reales de Vaca de Guzmán, premiado en 1778 e impreso ese mismo año, y a continuación el poema Granada rendida del propio Vaca de Guzmán (pp. 23-46) y La toma de Granada por los Reyes Católicos, de Moratín hijo (pp. 47-68). Don Leandro nunca le perdonó a don Joseph María sus dos victorias consecutivas. En 1785 publicó (probablemente con esos sus filiales retoques que se han hecho famosos) el poema con que don Nicolás había concursado en 1778, llamado asimismo Las naves de Cortés destruidas, con una introducción en que ponía este poema por encima del de Vaca de Guzmán. La réplica apareció dos años después, y no en Madrid sino en Alcalá: Advertencias que hace a los criticos, humanistas, y principalmente a los poetas, don Joseph María Vaca de Guzmán, autor del canto "Las naves de Cortés destruidas". (Véase Juan Catalina García, Ensayo de una tipografía complutense, Madrid, 1889, núm. 439). 
[\$ 208] Ibid., pp. 169 ss.: otros endecasílabos, llamados romances a secas.

[\$ 209] Poesias varias de M. H. [Margarita Hickey y Pellizoni], Madrid, 1789, pp. 348-363: larguísimo romance heroico endecasílabo.

[\$ 210] Romance endecasílabo para el dia que haga su entrada en publico en Valencia el... P. Fr. Joaquin Canpañy, ministro general de toda la Orden de San Francisco, Valencia, 1800. (Con lo cual cierro a la vez el siglo xviır y mi Catálogo, y me quedo con una extraña sensación: ¿qué habrá ocurrido? chabrá hecho ya su entrada en público ese superior general de los franciscanos?) .

Tabla I, que muestra los diferentes metros de los versos de romance (con exclusión de los pre-barrocos, o sea los de ocho, seis y siete silabas) y las diferentes estructuras estróficas

Coplas de cuntro versos

4-4-4-4: $\S 193$

5-5-5-5: $\$ \$ 92$ (letrilla), 95 (juguete)

9-9-9-9: $\$ \S 11,194$

10-10-10-10: $\$ \S 97$ (esdrújulos), 87 (romance endecasilabo), 136 (romance eneámetro), 37,89

11-11-11-11: \$§ 191 (copla castellana), 161, 204 (elegia), 169, 187 (endecasilabo), 189 (endecasilabos), 31, 76, 82, 145, 151, 154, 208 (romance), 36, 69, 75, 83, 128, 129, 133, 141, 157, 179 (romance de arte mayor), 178 (romance en endecasilabo), 24, 38, 47, 53, 64, 73, 77, 85, 91, 94 (?) , 134, 150, 158, 174, 176, 190, 202, 203, 207, 210 (romance endecasilabo), 17, 18, 52, 56, 59, 62, 67, 72, 74, 84, 88, 130, 138, 139, $140,142,143,152,155,156,159,167,175,177,181,184,186,188$, 195 (romance heroico), 209 (romance heroico endecasilabo), 61 (romance lirico), 182 (romance real), 99 (turdión), 22, 25, 28, 46, 65, 70, $98,147,164,166,168,201$

12-12-12-12: $\S \S 172$ (minué), 163

5-5-7-7: $\$ 27$

6-5-6-5: $\$ \$ 13$ (letrilla), 107 (cardador), 4

6-6-6-11: $\$ 101$

6-12-6-12: cf. \$ 45

7-5-7-5: $\$ \S 106$ (endechas), 171 (seguidillas), 162, 185 (y cf. 127)

7-5-7-7: $\$ 7$

7-6-6-6: cf. $\S 126$

7-6-7-6: $\$ 108$

7-7-7-4: § 146 (endechas) 
7-7-7-11: $\$ 205$ (elegia), 21, 57, 144 (endechas), 63, 66, 68, 131, 132, 135, 153 (endechas endecasilabas), 41, 165, 192, 196 (endechas reales), 205 (oda), 14 (romance), 58, 90, 103, 183 (romance endecasilabo), 15 (romance heroico), 34, 102, 160, 170, 200

7-11-7-11: $\$ \$ 42,79$ (y cf. 124)

8-4-8-8: $\$ 9$ (romance)

8-6-8-6: $\$ \S 109,197$

8-8-6-6: cf. $§ 173$

8-8-8-4: $\S 2$

8-8-8-5: $\$ \S 19,104$

8-8-8-10: $\$ \$ 20,148$

8-8-8-11: $\$ \$ 8$ (romance), 32 (romance disparado), 51 (romance "echasylavo"), 40, 50, 71, 86, 180 (romance endecasilabo), 35

8-8-8-12: $\$ 10$ (romance)

8-8-10-10: $§ 105$

8-8-11-11: $\$ 78$

10-6-10-6: $\$ 198$ (y cf. 123)

10-10-10-5: $\$ 81$

$10-10-10-9: \$ 80$

10-12-10-12: $\$ \S 112$ (canario), 111 (españoleta), 26 (letra), 39 (romance endecasilabo), 12, 29, 48, 110, 149

11-6-1 1-6: $\$ 199$

11-11-11-5: $\$ 206$ (oda)

Coplas De CINCo versos

7-7-7-7 + 10: $\$ 1113$ (endechas irregulares), 43

$7-7-7-7+12: \$ 114$

8-8-8-8 + 10: $\$ 49$

Coplas de SEIS versos

7-7-7-7 + 10-7: $\$ 93$

7-7-7-7 + 10-12: $\$ 44$

8-8-8-8 + 4-12: $\$ 117$

$8-8-8-8+6-6: \$ \$ 3,115$

8-8-8-8+7-5: $\$ 116$

8-8-8-8 + 8-12: $\$ 118$

COPLAS DE SIETE VERSOS

$6-12-6-12+6-6-6: \S 45$

7-11-7-11 + 5-7-5: $\$ 124$

$8-8-8-8+4-6-6: \S 119$

$8-8-8-8+4-7-5: \S 120$

$8-8-8-8+5-7-5: \$ 121$

8-8-8-8 + 5-8-8: $\$ 122$

8-8-8-8 + 11-6-7: $\$ 6$

10-6-10-6 + 6-7-6: $\$ 123$ 


\section{COPLAS DE OCHO VERSOS}

Octetas de hexasílabos o de octosílabos: $\S \S 1,5$

8-8-6-6 + 6-6-6-6: $\$ 173$ (letra)

8-8-8-8 + 6-6-6-6: $\$ \S 30,125$ (y cf. 96)

$8-8-8-8+7-5-7-5: \$ 127$

$8-8-8-8+7-6-6-6: \S 126$

Tabla II, que muestra, en orden alfabético, los nombres de los metros y de las estrofas

canario: $\$ 112$ (10-12-10-12)

cardador: $\$ \S 107$ (6-5-6-5), 96 nota (6-6-6-6)

copla castellana: $\$ 191$ (11-11-11-11)

elegia: $\$ \$ 205$ (7-7-7-11), 161, 204 (11-11-11-11)

endecasilabo(s): $\$ \S 169,187,189$ (11-11-11-11)

endechas: $\S \S 88$ (6-6-6-6), 146 (7-7-7-4), 21, 57, 144 (7-7-7-11)

endechas castellanas: $\$ 96$ nota (6-6-6-6)

endechas endecasilabas: $\$ \S 63,66,68,131,132,135,153$ (7-7-7-11)

endechas irregulares: $\$ 113(7-7-7-7+10)$

endechas reales: $\$ \S 41,165,192,196$ (7-7-7-11)

esdrújulos: $\$ 97$ (10-10-10-10)

españoleta: $\$ 111$ (10-12-10-12)

folias: $\$ 96$ nota $(6-6-6-6)$

juguete: $\S 95(5-5-5-5)$ y nota $106(6-6-6-6)$

laberinto: $\$ \S 46,(88), 100,137,(166)$

letra: $\$ \S 26(10-12-10-12), 179(8-8-6-6+6-6-6-6)$

letrilla: $\$ \S 13(6-5-6-5), 92,95$ nota $(5-5-5-5)$

minué: § 172 (12-12-12-12)

oda: $\$ \S 205 \quad(7-7-7-11), 206 \quad(11-11-11-5)$

panamá: $\S 96$ nota $(7-7-7-7)$

romance: $\$ \S 95$ nota $(5-5-5-5), 14$ (7-7-7-11), 9 (8-4-8-8), 8 (8-8-8-11),

10 (8-8-8-12), 31, 76, 82, 145, 151, 154, 208 (11-11-11-11)

romance castellano: $\$ 88$ (8-8-8-8)

romance de arte mayor: $\$ \S 36,69,75,83,128,129,133,141,157,179$

(11-11-11-11)

romance disparado: $\$ 32$ (8-8-8-11)

romance echasylavo: $\$ 51 \quad(8-8-8-11)$

romance en endecasilabo: $\$ 178$ (11-11-11-11)

romance endecasilabo: $\$ \S 58,90,103,183$ (7-7-7-11), 40, 50, 71, 86, 180

$(8-8-8-11), 87$ (10-10-10-10), 39 (10-12-10-12), 24, 38, 47, 53, 64, 73,

$77,85,91,94$ ( ) $, 134,150,158,174,176,190,202,203,207,210$ (1111-11-11)

romance eneámetro: $\$ 136(10-10-10-10)$

romance heroico: $\$ \S 15(7-7-7-11), 16,29,33,54,55,60(8-8-8-8), 17$, $18,52,56,59,62,67,72,74,84,88,130,138,139,140,142,149,152$, $155,156,159,167,175,177,181,184,186,188,195$ (11-11-11-11) 
romance heroico endecasilabo: $\S 209$ (11-11-11-11)

romance lirico: $\$ 61$ (11-11-11-11)

romance real: $\S 182$ (11-11-11-11)

seguidillas: $\$ 171 \quad(7-5-7-5)$

tocotin: $\$ 96$ nota $(6-6-6-6)$

turdión: $\$ 99$ (11-11-11-11)

Nota final, sobre los "usos" del romance heroico

Así como la historia de la novela constituye la mejor definición de la palabra "novela", así también la historia de las formas poéticas, por el hecho mismo de ser historia - vida vivida, estructura en funciones-, dice más acerca de ellas que las definiciones escrupulosamente circunscritas al plano sincrónico. "Ciego que apuntas y atinas..." es tan romance como "Ya cabalga Diego Ordóñez...", sí, ipero qué distinto como fenómeno poético, pese al octosílabo y a la asonancia!

El romance de once sílabas - objeto inicial del artículo que acaba de leerse (cf. supra, p. 414, nota 119) - tiene una historia relativamente simple. Respondió en sus orígenes a una intención "heroica" o de alto entusiasmo, pero, a medida que se fue extendiendo y generalizando como forma, comenzó a ser vehículo de otros variados impulsos poéticos. No siempre sirvió para celebrar a "héroes" (humanos o divinos) y, además, para los cantos heroicos y elevados hubo siempre otros metros disponibles. Sin embargo, puede decirse que los poetas de los siglos xvn y xvin supieron siempre que el romance de once sílabas se prestaba sobre todo para los asuntos "excelsos"; que para decir o cantar ciertas cosas grandes, para sugerir cierta exaltación de ánimo o cierta voluntad de énfasis servía ése más que otros metros.

Según se habrá visto en las dos Tablas, la designación romance heroico fue más frecuente que la designación romance endecasílabo (o de arte mayor, etc.), pero la mayor parte de los registrados en mi Catálogo son a la vez "endecasílabos" por su forma y "heroicos" por su tono y su contenido ${ }^{1}$. La designación romance endecasilabo fue la consagrada en 1779 por la Real Academia Española (\$ 202),

I Tengo la impresión de que en el siglo xix el panorama va a ser distinto. A nadie se le ocurriría decir que Bécquer escribió romances "heroicos", a pesar de que rimas como "Una mujer me ha envenenado el alma..." y "Cuando me lo contaron sentí el frío / de una hoja de acero en las entrañas..." son romances endecasílabos hechos y derechos. Pero no conozco bien la poesía española del siglo xix, y tal vez Bécquer no es muy representativo, o sea que tal vez también en el xix lo más frecuente es la coincidencia de lo endecasilabo con lo heroico. 
pero el tema del concurso por ella convocado - la toma de Granada por los Reyes Católicos- era uno de esos temas heroicos en grado sumo que pedían o exigían un metro prestigioso.

Claro que este prestigio del romance endecasílabo se insertaba en un prestigio mucho más amplio: el del verso endecasílabo, que conscientemente unas veces, inconscientemente otras, pero siempre de manera pertinaz y casi irresistible, se sentía más "noble" y "elevado" que el castizo octosílabo, bueno (según Luis Alfonso de Carvallo) un poco para todo, pero sobre todo para "las cosas medianas" 2. El metro con el que más lógica o fácilmente hubiera podido intercambiarse el romance endecasílabo no era otro romance (octosílabo, por ejemplo), sino otro poema en endecasílabos ${ }^{3}$, en particular la prestigiosísima octava real.

Por otra parte, al consagrar el romance endecasílabo como metro "sublime", la Academia remachó también un rasgo que le venía de origen, cierta artificialidad, cierta falta de espontaneidad, o sea un carácter que muy justa y objetivamente puede llamarse "académico". No pocos de los romances endecasílabos de mi Catálogo (v.gr. $\S \S 24,52,53,65,82-85,88,156,157,188$ ) son fruto de "academias" o tertulias literarias, y una parte del chiste de las fábulas 33 y 35 de Iriarte, las únicas hechas en romance heroico ( $\$ 195)$, es que las dos se refieren a "una tertulia de animales varios" 4.

2 Es probable que aún hoy se sienta más "noble" y "elevado" un soneto que una décima (en la medida en que aún hoy haya poetas que hagan sonetos y décimas, y en la medida también en que haya críticos que se interroguen sobre estas cuestiones, un tanto bizantinas quizá para la mayoría).

3 No hace falta aclarar que me refiero al endecasílabo de pedigree italiano, no al "de gaita gallega", al que verdaderamente, para evitar confusiones, valdría la pena poner siempre en saco aparte. El prestigio del endecasílabo a la italiana se ha mantenido sustancialmente intacto desde Garcilaso hasta Octavio Paz y muchos otros contemporáneos nuestros, pero el de gaita gallega ha sufrido enormes cambios desde el punto de vista de sus "usos": hay que ver la distancia que va de "Tanto bailé con el ama del cura..." a "Libre la frente que el casco rehusa..." Lo mismo se puede decir de otros metros ajenos al endecasílabo italianizante, que han rehusado más el casco y han tenido una frente más libre. He llamado la atención sobre las transformaciones del romance de 10-12-10-12, de Camargo (\$ 12) y Melo (\$ 26) a Calderón ( $\$ 29)$ y López de Reta (\$ 149). Añádase el ejemplo de Bécquer (rima I: "Yo sé un himno gigante y extraño / que anuncia en la noche del alma una aurora...") y se verá aún mejor esa movilidad que quiero destacar. (De manera parecida, ¿quién diría que "|Mexicanos! Al grito de guerra..." se remonta a "Molinito que mueles amores...?”').

4 La artificialidad y la pesadez del romance de once sílabas (véanse en el $\$ 22$ las palabras de Wilson y Blecua: "el pesado romance heroico", y cf. tam. bién, antes, la p. 356) no pueden entrar en su definición, porque su historia no se agota en esas cualidades negativas. Pero, por otro lado, no se puede olvidar que la artificialidad y pesadez es una parte de la historia. (Pienso, por 
El romance endecasílabo sirvió para hacer poemas descriptivos $(\$ \S 28,154,169)$; sirvió para hacer poemas meditabundos, de un tipo para el cual los amigos de las Reglas y enemigos del Barroco -un Hermosilla, un Menéndez Pelayo-hubieran prescrito más bien el verso suelto o los tercetos de la "elegía" y la "epístola" renacentistas (v.gr. $\$ \S 22,91,147,152,161,204$ ) ; sirvió, de manera notable, para elogiar a escritores, actividad en sí misma altamente sospechosa de academicismo $(\$ \S 47,128,129,130,133,134,145,150$, 164) ; sirvió para traducir las cartas erótico-mitológicas de Ovidio (\$\$ 168 y 191) ; sirvió para otros diversos objetos, y alguna vez (\$61) llegó incluso a llamarse romance lírico.

Pero sirvió sobre todo para celebrar a altos personajes, encomiables por su heroica sangre o su heroico dinero (v.gr. $\$ \S 18,24,67$, $99,152,154,186)$, o bien por sus heroicas virtudes de santidad, como San Francisco Javier ( $\$ \S 82-85,88)$, San Pascual Baylón ( $\$ \S$ 139 y 140) y San Juan de Dios $(\$ \$ 141,142 \text { y } 143)^{5}$, y aun la Santísima Trinidad y la Santísima Virgen $(\$ 134)$. A lo largo de la época estudiada, se encuentra a sus anchas cuando canta los loores de las testas coronadas: Felipe IV (\$ 31) y su mujer Mariana de Austria ( $\$ 36)$, Carlos II ( $\$ \$ 56,69,70,73,74,98,138)$ y su mujer María Luisa de Borbón (§ 91), Felipe V (\$§ 156, 166, 167), su padre $(\$ 161)$ y sus hijos Luis I ( $\$ \S 155$ y 166), Fernando VI ( $\$ 174)$ y Carlos III ( $\$ \S 175,182,187$ ), además de los Reyes Católicos (\$\$202 y 203) y de Carlos V (\$ 25). Y habría sido una anomalía que los cantos a asuntos tan heroicos como "la armada de Francia" (\$ 59), la muerte de don Manuel Diego López de Zúñiga "de vn mosquetaço que recibió en vn assalto de Buda, capital de Vngría" (\$ 152), las victorias colonialistas de España en Orán (\$ 178) o el bombardeo de Argel (\$ 189) -sin olvidar la toma de Granada- se hubieran compuesto en un metro menos "heroico" *

Los romances heroicos de Sor Juana (\$\$ 99 y 100$)$ son extra-

lo demás, que el romance endecasílabo no salió tan mal librado de la mencionada consagración como la "lira" o la "estrofa sáfica", que en manos de los poetas académicos de fines del siglo xvm y de gran parte del xIx llegaron a un grado máximo de acartonamiento).

5 En el núm. 143, como se recordará, el poeta "presume" balancear a dos héroes, San Juan de Dios y Santiago Matamoros.

6 Fatalmente, esto tenía que hacer del romance heroico el vehículo de la tragedia y del drama "elevado", la respuesta académica española al reto académico francés del pareado de alejandrinos. (Pero he evitado adrede meterme en esto, y he excluido los ejemplos de obras teatrales de fines del siglo xviII, salvo el Guzmán el Bueno de Iriarte y su parodia por Samaniego, $\$ \$ 195$ y 201). - Por otra parte, no olvido que también las endechas reales sirven a finalidades bélicas ( $\$ 58$ y 90 ), y que a Carlos II se le canta no sólo en romances de once sílabas, sino también en romances de ocho $(\$ 55)$ y en endechas $(\$ 41)$. 
ordinariamente "ortodoxos". Uno de ellos está dedicado a Carlos II: "A los años alegres y festivos / del soberano, el invencible Carlos..."; dos, al virrey Marqués de la Laguna: "Al invencible Cerda esclarecido..." y "A las excelsas, soberanas plantas / del soberano, esclarecido Cerda..."; y tres, a la Virgen María exaltada a los cielos en su Asunción: "En trono de zafir, Reina triunfante..." (núm. vii, de 1677), "A las excelsas, imperiales plantas / de la triunfante, poderosa Reina..." (núm. 272, de 1685) y "Fabricó Dios el trono del Empíreo..." (núm. 308, de 1690). Se diría que en estos casos Sor Juana se pone rígida y monocorde y "académica": se exhibe ostentosamente, en el comienzo mismo, el vocabulario elevado - Reina, regio, trono, empireo, imperial, soberano, triunfante, invencible-, y hasta la estructura sintáctica de la frase inicial en cuatro de los seis romances es prácticamente la misma. El séptimo y último (1691) de los romances endecasílabos no tiene esa estructura ni ese vocabulario en el primer verso ("Ya fuese vanidad, ya providencia..."), pero ya el verso 2 menciona al invicto Ptolomeo Filadelfo, soberano de Egipto, supuesto promotor de la traducción griega alejandrina de la Biblia (la versión de los LXX) y supuesto antepasado de la supuesta Catalina de Alejandría, y a lo largo de la composición reaparece la palabra clave: "Mas ¿por qué, oh cielos, por qué a un rey pagano / concedió Dios tan alto privilegio...”; “¡Oh Providencia altísima, ¿quién duda / que sólo fue por ascendiente regio / de Catarina...?”; "Goza, Egipto dichoso, ese florido / de tantos regios árboles renuevo..." Verdaderamente el romance heroico, en manos de Sor Juana, sirve tan sólo para celebrar a los reyes.

El Colegio de México. 